\title{
A sejtmagi Moesin importjának és funkciójának vizsgálata
}

\author{
Ph.D. értekezés \\ Szerző: Bajusz Csaba \\ Témavezető: Dr. Vilmos Péter
}

Szegedi Biológiai Kutatóközpont

Genetikai Intézet

Szegedi Tudományegyetem

Természettudományi és Informatikai Kar

Biológia Doktori Iskola

2020.

Szeged 
1. BEVEZETÉS

1.1. Citoszkeletális fehérjék a sejtmagban ..........................................................4

1.1.1. Tubulin fehérjék ..............................................................................................5

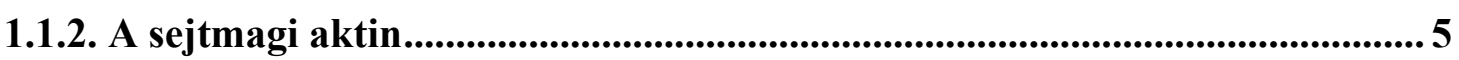

1.1.3. Aktinszerü fehérjék (Actin related proteins - Arps) ....................................8

1.1.4. Aktinkötő fehérjék a sejtmagban................................................................9

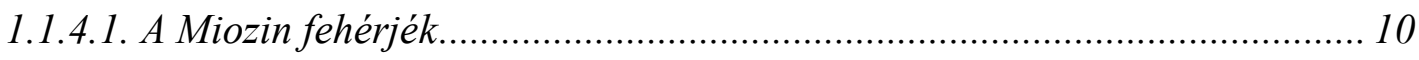

1.1.4.2. Spektrin motívumot tartalmazó fehérjék.................................................. 10

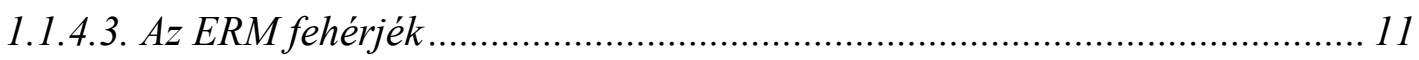

1.1.4.3.1. A Drosophila Moesin fehérje ............................................................... 14

2. ANYAGOK ÉS MÓDSZEREK ..................................................................... 16

2.1. Drosophila melanogaster keresztezések és módszerek .......................................... 16

2.1.1. A moe[NES]DsRed mutáns vonalak létrehozása ............................................. 17

2.1.2. A DsRed markergén eltávolítása ......................................................................... 18

2.1.3. A kapcsolt $X$ kromoszómákat tartalmazó moe[NES] vonalak létrehozása 18

2.1.4. A moe[NES] mutáns legyek élettani jellemzése .................................................. 19

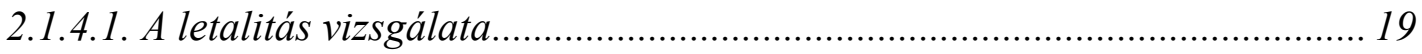

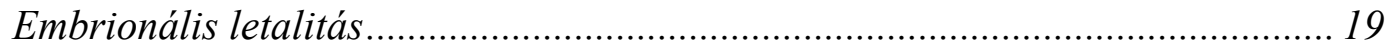

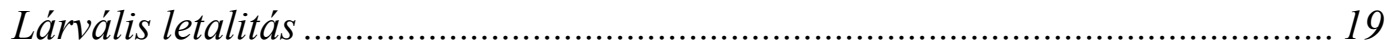

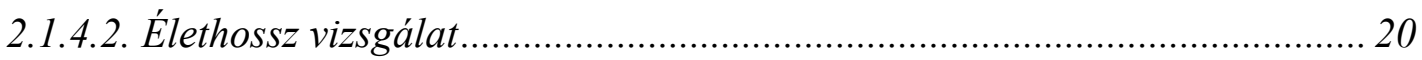

2.1.4.3. A moe[NES] mutánsok éhezési stressz türése ........................................... 20

2.1.4.4. A moe[NES] mutáns nöstények petehozama ............................................. 20

2.1.4.5. A moe[NES] mutánsok mászóképessége.................................................... 20

2.1.4.6. Transzpozonok szabályozásának vizsgálata petefészekben........................ 20

2.1.5. Mellékhatások kizárása ............................................................................ 21

2.1.5.1. A CRM1 útvonal épségének ellenörzése ...................................................... 21

2.1.5.2. Citoplazmatikus funkciók épségének ellenörzése ...................................... 21

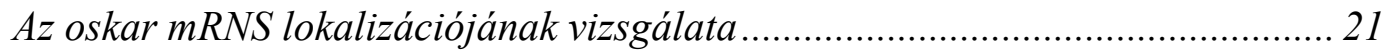

A Vasa fehérje lokalizációjának vizsgálata petefészekben illetve embriókban .... 21

A Moesin-NES fehérje aktivációjának és lokalizációjának vizsgálata ................. 21

2.1.6. Élő petefészkek vizsgálata mikroszkóppal.................................................... 22

2.1.7. Élő Drosophila embriók vizsgálata mikroszkóppal...................................... 22

2.1.8. Petefészkek preparálása és immunfestése...................................................... 22

2.1.9. Hősokkolt nyálmirigyek preparálása és immunfestése................................. 23 
2.1.10. Petefészkek X-gal festése ..................................................................................... 23

2.1.11. Fluoreszcens in situ hibridizáció (FISH) ....................................................... 24

2.2. Molekuláris biológiai módszerek......................................................................... 24

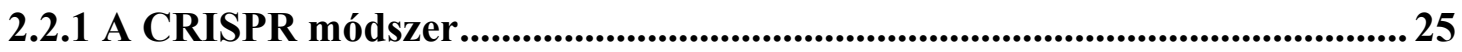

2.2.1.1. A CRISPR gRNS-ek létrehozása és tesztelése.......................................... 25

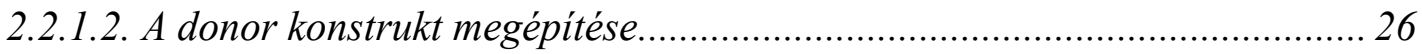

2.2.1.3. A NES szekvencia génbe épülésének ellenörzése PCR-rel ......................... 28

2.2.1.4. A moe[NES] génröl képzödö mRNS izolálása és szekvenálása................... 28

2.2.2. Genomi DNS izolálása egy légyből................................................................ 29

2.2.3. Teljes mRNS szekvenálás ........................................................................29

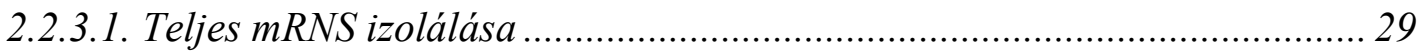

2.2.3.2. Teljes mRNS minták elökészitése a szekvenáláshoz ................................ 30

2.2.3.3. Teljes mRNS szekvenálás adatainak a feldolgozása ................................. 30

2.2.4. Kvantitatív PCR (qPCR) ............................................................................................ 30

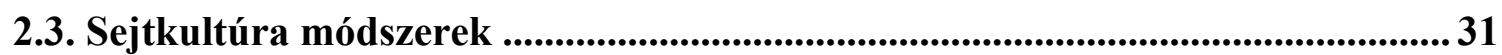

2.3.1. Az S2R+ sejtek fenntartása, transzfekciója .................................................... 31

2.3.2. S2R+ sejtek immunfestése ...................................................................... 31

2.3.3. A transzfekcióhoz használt expressziós konstruktok elkészítése .................. 32

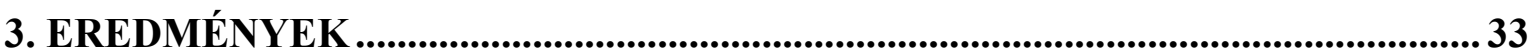

3.1. A sejtmagi import vizsgálata ..................................................................33

3.1.1. A Moesin NLS szekvenciájának azonosítása .................................................33

3.1.2. A sejtmagi import szabályozása.................................................................... 36

3.1.3. A Moesin aktivációs állapota és sejtmagi transzportja közötti kapcsolat vizsgálata ....................................................................................................................................... 38

3.1.4. A sejtmagi import aktinfüggése ............................................................................... 42

3.2. A sejtmagi funkció vizsgálata ............................................................................................ 43

3.2.2. A moe[NES] törzs létrehozása ............................................................................... 47

3.2.3. A moe[NES] mutánsok fenotípusai........................................................................ 48

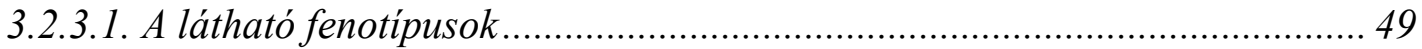

3.2.3.2. A moe[NES] mutánsok élettani jellemzése ................................................ 55

A moe[NES] mutáns nöstények petehozama ..................................................... 55

A moe[NES] nöstények embrióinak életképessége ............................................. 56

A moe[NES] mutánsok embriókor utáni életképessége ..................................... 57

A moe[NES] mutánsok éhezési stressz türése .................................................. 58

A moe[NES] mutánsok mászóképessége ............................................................. 59 
3.2.3.3. A moe[NES] mutáns vonalak anyai hatású sterilitása 60

A MoeNES fehérje citoplazmatikus funkcióinak vizsgálata...... 61

A MoeNES fehérje aktivációja és lokalizációja. 61

A CRM1 útvonal épsége. 62

3.2.3.4. Az anyai hatású sterilitás oka. 63

Az ivarszervek vizsgálata a moe[NES] anyák és nöstény utódaik petefészkeiben 63 Az ivarsejtek vizsgálata a moe[NES] anyák embrióiban..... 64

Transzpozon aktivitás vizsgálata a moe[NES] nöstények petefészkeiben. 65

Az anyai hatású faktorok vizsgálata a moe [NES] anyák ováriumában.. 66

3.2.3.5. A transzkripció vizsgálata a moe[NES] anyák ováriumában. 69

3.2.3.6. A sejtmagi Moesin szükséges a hösokk gének normális müködéséhez 76

A MoeNES fehérje nem tud hősokk hatására a sejtmagban felhalmozódni .. 78

A hsp gének transzkripciósszintjeinek változása hösokk hatására 79

4. AZ EREDMÉNYEK MEGVITATÁSA ÉS TOVÁBBMUTATÁS ...........................81

5. TARTALMI ÖSSZEFOGLALÓ ...............................................................................8 87

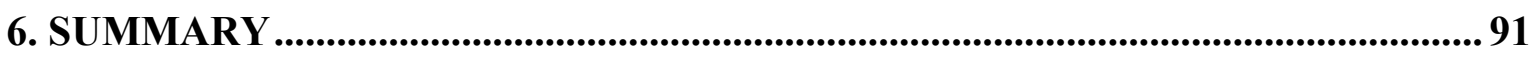

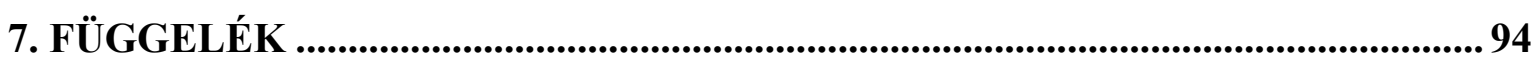

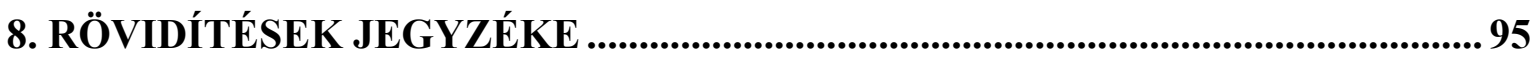

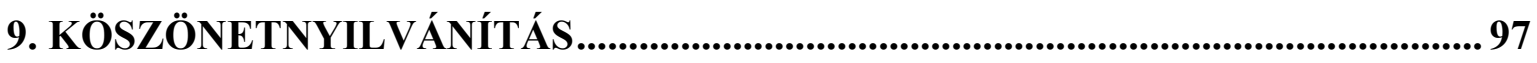

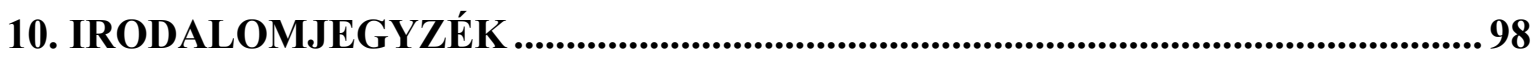

11. SAJÁT KÖZLEMÉNYEK LISTÁJA .................................................................... 105 


\section{BEVEZETÉS}

\subsection{Citoszkeletális fehérjék a sejtmagban}

A közelmúltban megjelent számos tanulmányban bizonyítást nyert, hogy a citoszkeletális fehérjék jelentős része, köztük a tubulin, az aktin és aktinszerü fehérjék, aktinkötő fehérjék és miozinok megtalálhatóak a sejtmagban is, ahol a DNS-hibajavításban, transzkripcióban, valamint kromatin átrendező és transzport folyamatokban résztvevő komplexek tagjaiként müködnek (Kumeta és mtsai, 2012) (1. táblázat).

\begin{tabular}{|c|c|c|c|}
\hline & $\begin{array}{c}\text { Elsődleges } \\
\text { lokalizációs hely }\end{array}$ & Sejtmagi kötőpartner & Sejtmagi funkció \\
\hline aktin & citoplazma & $\begin{array}{l}\text { RNS pol. I/II/III; } \\
\text { transzkripciós faktorok; } \\
\text { kromatin módosító és } \\
\text { átrendező komplexek; } \\
\text { hnRNP; nukleáris } \\
\text { lamina; NPC; stb. }\end{array}$ & $\begin{array}{l}\text { transzkripció; DNS } \\
\text { hibajavító } \\
\text { folyamatok; mRNS } \\
\text { transzport }\end{array}$ \\
\hline nukleáris miozin & sejtmag & RNS pol. I/II & transzkripció \\
\hline miozin II & citoplazma & RNS pol. II & transzkripció \\
\hline miozin $\mathrm{Va}$ & citoplazma & & \\
\hline miozin $\mathrm{Vb}$ & sejtmag & RNS pol. I & transzkripció \\
\hline miozin VI & citoplazma & RNS pol. II & transzkripció \\
\hline kofilin & citoplazma & RNS pol. II & transzkripció \\
\hline N-WASP & citoplazma & RNS pol II & transzkripció \\
\hline Arp4 & sejtmag & $\begin{array}{l}\text { kromatin átrendező } \\
\text { komplex }\end{array}$ & $\begin{array}{l}\text { transzkripció; DNS } \\
\text { hibajavító } \\
\text { folyamatok; } \\
\text { kromatin módosítás }\end{array}$ \\
\hline Arp5 & sejtmag & $\begin{array}{l}\text { kromatin átrendező } \\
\text { komplex }\end{array}$ & $\begin{array}{c}\text { transzkripció; DNS } \\
\text { hibajavító } \\
\text { folyamatok; } \\
\text { kromoszóma } \\
\text { szegregáció } \\
\end{array}$ \\
\hline Arp6 & sejtmag & $\begin{array}{l}\text { kromatin átrendező } \\
\text { komplex; HP1 }\end{array}$ & $\begin{array}{c}\text { transzkripció; } \\
\text { kromatin módosítás }\end{array}$ \\
\hline Arp8 & sejtmag & $\begin{array}{l}\text { kromatin átrendező } \\
\text { komplex; mitotikus } \\
\text { kromoszómák }\end{array}$ & $\begin{array}{c}\text { transzkripció; DNS } \\
\text { hibajavító } \\
\text { folyamatok; } \\
\text { kromoszóma } \\
\text { szegregáció } \\
\end{array}$ \\
\hline actinin-4 & citoplazma & $\begin{array}{c}\text { kromatin átrendezö } \\
\text { komplex }\end{array}$ & transzkripció \\
\hline nesprin fehérjék & sejtmag & $\begin{array}{c}\text { lamin } \mathrm{A} / \mathrm{C} ; \mathrm{ERK} 1 / 2 ; \\
\text { PML-testek }\end{array}$ & $\begin{array}{c}\text { szignáltranszdukciós } \\
\text { útvonalak }\end{array}$ \\
\hline$\alpha$ SpecII & citoplazma & FANCA; FANCG; XPF & $\begin{array}{c}\begin{array}{c}\text { DNS hibajavító } \\
\text { folyamatok }\end{array} \\
\end{array}$ \\
\hline$\beta$ SpecIV $\Sigma 5$ & sejtmag & PML-testek & PML-test kialakítás \\
\hline
\end{tabular}

\section{1. táblázat Citoszkeletális fehérjék sejtmagi funkciói (Kumeta és mtsai, 2012).}




\subsubsection{Tubulin fehérjék}

A tubulinok esetében hét különböző családot különböztetünk meg: $\alpha-, \beta-, \gamma-, \delta$-, $\epsilon$-, $\zeta$ - és $\eta$-tubulint, melyek különböző tubulin izoformákból állnak. Az $\alpha$ és $\beta$ tubulin dimerek építik fel a mikrotubulusokat, míg a $\gamma$-tubulinok a centroszómák kialakításában, valamint a mikrotubulusok nukleációjában vesznek részt. A további tubulin izoformákat az 1990-es és 2000-es években írták le; feltehetően a centriólumok és a bazális testek felépítésében játszhatnak szerepet (McKean és mtsai, 2001). Emlősök esetében hat $\alpha$ és hét $\beta$ izoformát különböztetünk meg, melyek föként az $\mathrm{N}$ - és $\mathrm{C}$-terminális részeikben különböznek. A különféle tubulin izoformák hatással vannak a mikrotubulusok stabilitására és funkciójára (Akoumianaki és mtsai, 2009). Már 1980-ban kimutatták, hogy a tubulinok jelen vannak a sejtmagban is, ott a kromatinnal asszociálva találhatók meg (Menko és Tan, 1980). Immunhisztokémiai vizsgálatokkal később megállapították azt, hogy a fő sejtmagi tubulin a $\beta$ II izoforma (Walss-Bass és mtsai, 2002; Xu és Luduena, 2002), illetve hogy a tubulin koimmunprecipitálható egy transzkripciós koaktivátorral, az ASC-2 fehérjével (Goo és mtsai, 2003), és az aktivált Notch1 (N1IC) receptorral (Yeh és mtsai, 2004). Ugyanakkor azonban olyan közlemények is napvilágot láttak, melyek vitatják a tubulin normál körülmények közötti sejtmagi lokalizációját és funkcióját. Az ezekben megfogalmazott fö kritika az, hogy a tubulinokat tumoros sejtvonalak magjaiban vizsgálták, míg a normál sejtek magvaiban nem sikerült őket kimutatni (Walss-Bass és mtsai, 2002).

\subsubsection{A sejtmagi aktin}

Az aktin fehérjék az aktinszerü és a hősokk fehérjékkel (pl. Hsp70), valamint egyes enzimekkel (pl. hexokináz), továbbá ATP kötésére képes prokarióta fehérjékkel (pl. FtsA, MreB, ParM) együtt alkotják az aktin szupercsaládot (1. ábra) (Kabsch és Holmes, 1995). A család első képviselöjének megjelenése a baktériumok, archeák és eukarióták közös ősében, tehát még jóval a sejtmag megjelenése előtt valószínüsíthető (Erickson, 2007; Bajusz és mtsai, 2018). Az aktin szupercsalád tagjainak legfontosabb feladata a polimerizációs képességük révén a citoszkeletális mikrofilamentum rendszer kialakítása, így ennek megfelelően részt vesznek a sejtalak fenntartásában és a sejtosztódásban (Erickson, 2007). 


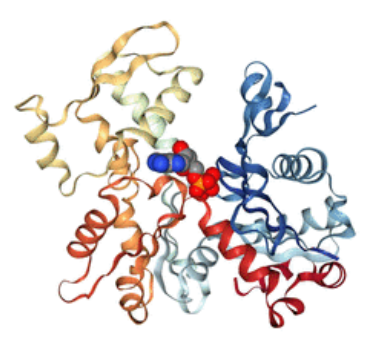

Actin

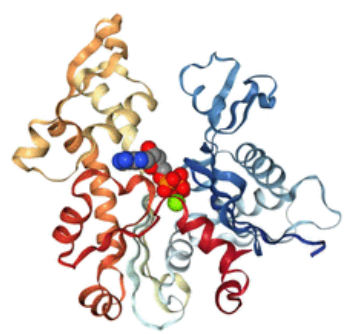

MreB

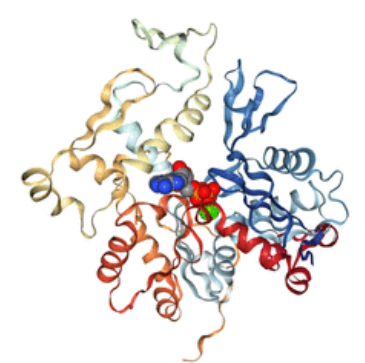

ARP4

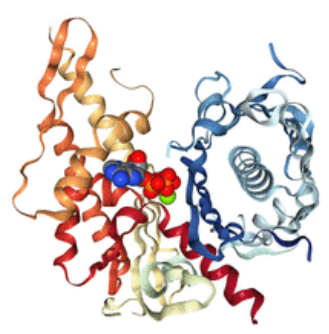

ParM

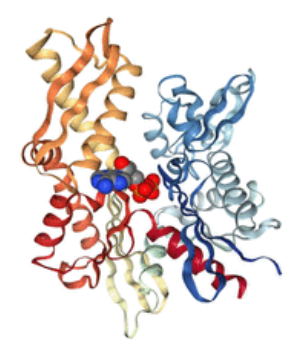

Hsp70

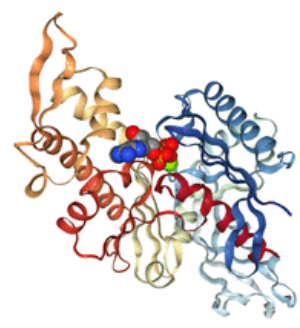

FtsA

1. ábra Az aktin és az eukarióta, valamint prokarióta aktinszerü fehérjék közötti térszerkezeti hasonlóságok (Bajusz és mtsai, 2018).

Az aktin az eukarióta sejtek egyik legnagyobb mennyiségben és legáltalánosabban előforduló fehérjéje. Az evolúció során a gerincesekben az aktinnak három fő izoformája alakult ki (alfa, béta, gamma izotípusok), melyeket expressziós helyük alapján további alcsoportokra oszthatunk (Pollard, 2001). Az alfa izoformák az izomrostok kialakításában vesznek részt, míg a béta és gamma típusú aktinok minden sejtben termelödnek és főként a citoszkeletális vázrendszer kialakításában vesznek részt. Az egyes izoformák aminosav szekvenciáiban nagyfokú hasonlóság figyelhető meg. A szekvenciában megjelenő különbségek főként a fehérjék N-terminális részét érintik (2. ábra) (Perrin és Ervasti, 2010).

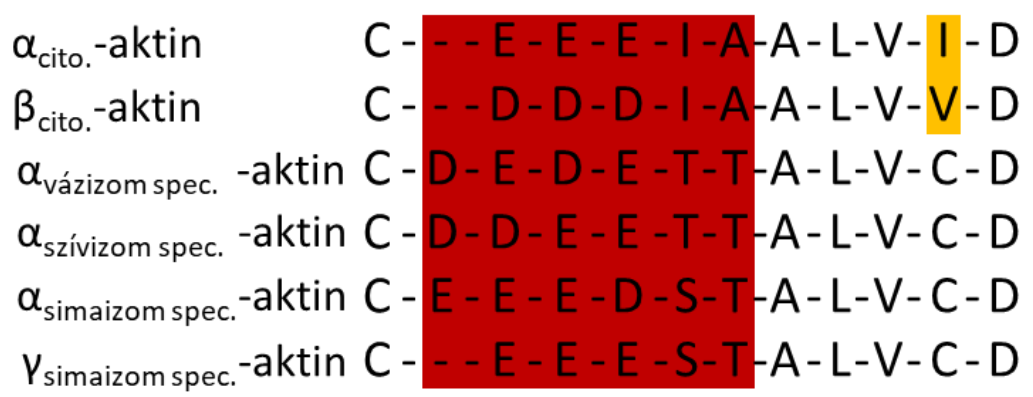

2. ábra Az aktin izoformák szekvenciái közötti különbségek.

Az izom- és a citoszkeleton-specifikus aktin típusok közötti különbségek pirossal, míg a két citoszkeletális izoforma közötti eltérések sárgával vannak jelölve

(Perrin és Ervasti, 2010). 
Az aktin sejtmagi jelenlétét elsőként Ohnishi és munkatársai mutatták ki biokémiai módszerekkel szarvasmarha timociták izolált sejtmagjaiban 1963-ban (Ohnishi és mtsai, 1963). A kor tudományos közvéleménye az eredményeket müterméknek gondolta, mivel a citoplazmában nagy mennyiségben jelenlévő aktin szennyezhette a sejtmagi izolátumot. Az aktin sejtmagi jelenlétének vizsgálatát nehezítette az a tény is, hogy sokáig nem álltak rendelkezésre sem megfelelő mikroszkópos módszerek, sem az aktint jelölő érzékeny festési eljárások, melyek lehetővé tették volna a nukleáris aktin tanulmányozását. Később, a 90-es, de főleg a 2000-es években a fejlettebb vizsgálati módszerek megjelenésével, a fluoreszcens mikroszkópos és biokémiai megközelítésekkel bizonyossá vált a sejtmagi aktin léte. Specifikus ellenanyagok és ún. nanobody-k alkalmazásával később már nem csak G-aktint, hanem filamentáris aktin struktúrákat is sikerült láthatóvá tenni a sejtmagban (Schoenenberger és mtsai, 2005). McDonald és munkatársai „fluorescence recovery after photobleaching” (FRAP) vizsgálatokkal azt is bizonyították, hogy az aktin a sejtmagban két frakcióra osztható: egy mobilis és egy kevésbé diffúz, immobilis frakcióra (McDonald és mtsai, 2006).

Ma már a sejtmagi és a citoplazmatikus aktin készletek közötti kapcsolat jól jellemzett. Maga az aktin fehérje ugyan nem tartalmaz sejtmagi lokalizációs szignálszekvenciát (Hofmann, 2009), ám monomer formában a kofilin és az Importin9 fehérjékkel kapcsolódva hatékonyan képes a sejtmagba szállítódni (Dopie és mtsai, 2012). A sejtmagból a citoplazmába irányuló transzportja pedig az aktin két, leucinban gazdag exportszignálja révén valósul meg. Emlősök esetében a sejtmagi export az Exportin1 segítségével, illetve a profilin és Exportin6 fehérjékkel alkotott komplex formájában történik (Falahzadeh és mtsai, 2015).

Az elmúlt másfél évtizedben az aktin sejtmagi funkcióira irányuló vizsgálatok feltárták, hogy a fehérje szinte minden alapvető sejtmagi folyamatnak fontos szereplöje. Így például számos tanulmány bizonyítja, hogy az aktin a kromatint módosító és átrendező komplexek része (Blessing és mtsai, 2004), és hogy jelen van a NuA4 (hiszton aciltranszferáz) kromatin módosító, illetve az INO80, SWI/SNF, SWR1 kromatin átrendező komplexekben (Knoll és mtsai, 2018), ezáltal közvetlenül részt vesz a kromatin módosításának és szerkezetének a szabályozásában (Kapoor és Shen, 2014).

A sejtmagi aktin DNS-hibajavításban betöltött szerepére utal, hogy sejtmagi mennyiségének csökkenésével a DNS károsodások gyakorisága megemelkedik (Belin és mtsai, 2015). DNS károsodás hatására aktin pálcák kialakulását figyelték meg a sejtmagban, ugyanakkor filamentáris aktin képződést más körülményekkel is (hőstressz, Latrunculin 
vagy DMSO kezelés, illetve vírusfertőzés) sikerült indukálni a sejtmagban (Kalendová és mtsai, 2014). Az is bizonyítást nyert, hogy az F-aktin nukleációban szerepet játszó Formin2 és Spire1/2 fehérjék magi jelenléte is nélkülözhetetlen a DNS károsodás során létrejövő nukleáris aktin struktúrák kialakulásához (Belin és mtsai, 2015).

Az aktin és a transzkripció közötti kapcsolatról egy 1979-es tanulmány számolt be elsőként. Smith és munkatársainak sikerült az RNS polimeráz II-vel együtt izolálni monomer aktint nyálkagombából (Physarum polycephalum) (Smith és mtsai, 1979). A későbbiekben mások kimutatták, hogy az aktin a többi RNS polimerázzal is koimmunprecipitálható (Percipalle és Visa, 2006), továbbá, hogy aktin hiányában a preiniciációs komplex nem szerelődik össze (Hofmann és mtsai, 2004), és aktin szükséges a génátírás iniciációs és elongációs lépései közötti átmenethez is (Percipalle, 2013). Ugyanakkor fontos megemlíteni, hogy az aktin nem csak a transzkripciós komplex részeként vesz rész a génátírás szabályozásában. Az SRF (Serum Response Factor) útvonal által szabályozott gének aktivációja a monomer és polimerizált aktin arányán, valamint a sejtmagi és citoplazmatikus aktin készletek közötti dinamikus kapcsolaton alapul. A szérum stimulus által indukált aktin polimerizáció következtében a MAL fehérje (Myocardin-related transcription factor A) és a G-aktin közötti kapcsolat a lecsökkent monomer aktin szint miatt nem képes kialakulni. A MAL az így szabaddá váló nukleáris lokalizációs szignálja (NLS) révén bejut a sejtmagba, ahol az SRF transzkripciós faktorral együttmüködve aktiválja a célgéneket. Emelkedett Gaktin szint esetén a MAL és a G-aktin alkotta dimerek kialakulása miatt a MAL fehérje felszínén levő NLS szekvencia hozzáférése megszünik, így az nem képes a citoplazmából a sejtmagba szállítódni (Guettler és mtsai, 2008). A legutóbbi időkben kiderült, hogy az aktinnak a MAL fehérje esetében leírt szabályozó mechanizmusa nem egyedi, a YAP/TAZ transzkripciós faktorok aktivitását is ugyanez a mechanizmus szabályozza (Wesolowska és Lenart, 2015).

\subsubsection{Aktinszerü fehérjék (Actin related proteins - Arps)}

Az aktinhoz hasonlóan számos aktinszerü fehérje is megtalálható a sejtmagban. Szerkezetük az aktinéval egyezően négy konzervált doménből és a központi ATP-kötő zsebből áll. A doméneken belül specifikus aldomének különíthetők el, melyek az adott aktinszerü fehérjére jellemző struktúrák (Oma és Harata, 2011). Az aktinszerü fehérjék és az aktin között fennálló szerkezeti azonosság ellenére nagyfokú szekvenciális különbségek 
figyelhetök meg közöttük. Az egyes aktinszerü fehérjék és az aktin között 38-69\%-os hasonlóság áll fenn (Dion és mtsai, 2010).

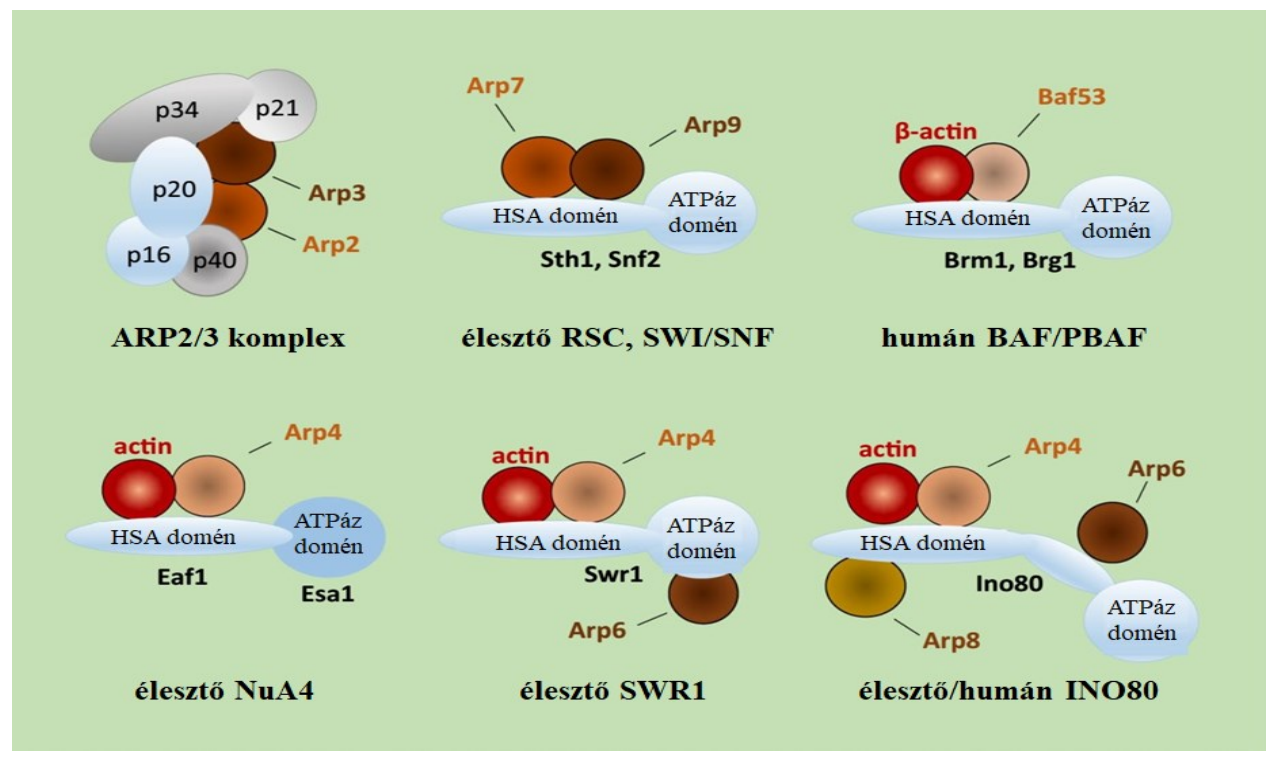

\section{3. ábra Aktinszerü fehérjéket tartalmazó kromatin módosító és átrendező faktorok élesztőben és emberben (Kristó és mtsai, 2016).}

Mind élesztő gombákban, mind emberben az aktinszerü fehérjék egyéb sejtmagi funkcióik mellett (Kristó és mtsai, 2016) a kromatin módosító és átrendező komplexeknek is tagjai (3. ábra). Érdekes megfigyelés, hogy az Arp6 az SWR1 kromatin átrendező komplextől független módon is képes a kromoszómákhoz kapcsolódni (Oma és Harata, 2011). Az Arp2 és Arp3 fehérjék ugyanakkor egyetlen kromatin módosító és átrendező komplexnek sem tagjai, fő funkciójuk az RNS polimeráz II által átírt gének szabályozása (Yoo és mtsai, 2007).

\subsubsection{Aktinkötő fehérjék a sejtmagban}

Az aktin sejtmagi funkciójának jelentőségét tovább erősíti az a tény is, hogy az aktinkötő fehérjék, melyek fő funkciójukból adódóan (F-aktin struktúrák fenntartása, szabályozása) nagyobb mennyiségben a citoplazmában találhatók meg, egy részéről mára már bizonyítást nyert a sejtmagi lokalizációjuk. Az első, sejtmagban is előforduló miozin izoformát Pestic-Dragovich és munkatársai írták le 2000-ben (Pestic-Dragovich és mtsai, 2000), míg a spektrin motívumot tartalmazó fehérjék sejtmagi lokalizációját később számos kutatás bizonyította (Kumeta és mtsai, 2012). Az Ezrin, Radixin, Moesin (ERM) fehérjék sejtmagi jelenlétét elsőként Batchelor és munkatársai igazolták (Batchelor és mtsai, 2003). 


\subsubsection{A Miozin fehérjék}

A Miozinok az aktin-alapú mozgásban szerepet játszó motorfehérjék, melyek a mozgáshoz szükséges energiát az ATP hidrolíziséből fedezik. Napjainkban bizonyítottá vált, hogy a különféle Miozin izoformák az aktinhoz hasonlóan szintén megtalálhatók a sejtmagban (De Lanerolle, 2012). Az elsőként leírt sejtmagi Miozin a nukleáris Miozin I (NMI) (Pestic-Dragovich és mtsai, 2000), mely részt vesz az RNS polimeráz II által átírt gének transzkripciójában (De Lanerolle, 2012), illetve a riboszómális gének átírásában (Philimonenko és mtsai, 2004). A későbbiekben számos más Miozin izoforma sejtmagi lokalizációja is bizonyítást nyert (1. táblázat) (De Lanerolle, 2012). A Miozin II az ICAM-1 (Intercellular Adhesion Molecule 1) gén esetében a preiniciációs komplex összeszerelődésében (Li és Sarna, 2009), míg a Miozin Va az RNS érésében játszik szerepet (Pranchevicius és mtsai, 2008). A Miozin Vb izoforma a sejtmagvacskákban az aktinnal együtt az RNS polimeráz I transzkripciós komplex tagja (Lindsay és McCaffrey, 2009), a Miozin VI pedig hasonlóan az NMI-hez, részt vesz az RNS polimeráz II irányította génkifejeződésben (Vreugde és mtsai, 2006). Az eddig felsoroltakon túl egyéb Miozin izoformákat is azonosítottak a sejtmagban, melyek a sejtciklus szabályozásában vesznek részt (Miozin XVI), vagy feltehetően tumor szuppresszor hatással bírnak (Miozin MVIII) (De Lanerolle, 2012).

\subsubsection{Spektrin motívumot tartalmazó fehérjék}

Szerkezetük közös jellemzője az evolúciósan konzervált, egyes prokarióta és eukarióta fehérjékben egyaránt megtalálható, három alfa hélixből felépülő spektrin motívum. Ezen típusú fehérjék a spektrin doménjeikkel képesek keresztkötni az aktin filamentumokat, így kiterjedt aktin hálózatot, illetve kötegeket hoznak létre a citoplazmában. A sejtmagi folyamatokban szerepet játszó spektrin doméneket tartalmazó fehérjék funkcióit a 4. ábra foglalja össze. A Muscle A kináz (mAKAP) a sejtmag membránjához köti a Ryanodine (RyR) receptort, melynek aktivitását is szabályozza a protein kináz A-val (PKA) együttmüködve (Young és Kothary, 2005). Az alfa spectrin II ( $\alpha$ SpecII) esetében pedig kimutatták a DNS hibajavításban szerepet játszó FANCA (FA) és XPF fehérjékkel a közvetlen kapcsolatot (Sridharan és mtsai, 2003). A béta spectrin IV $\Sigma 5$ ( $\beta \operatorname{SpecIV} \Sigma 5$ ) a promielocitás leukémia-testekben (PML) lokalizálódik (Young és Kothary, 2005), mely szerepet játszik a DNS replikációban, valamint a hibajavító mechanizmusokban, továbbá a 
transzkripció szabályozásában (Borden, 2002). A Nesprin különféle izoformái pedig az aktin filamentumokkal (MF), valamint a laminokkal és az emerinnel (EM) alakítanak ki kapcsolatot (Sridharan és mtsai, 2003).

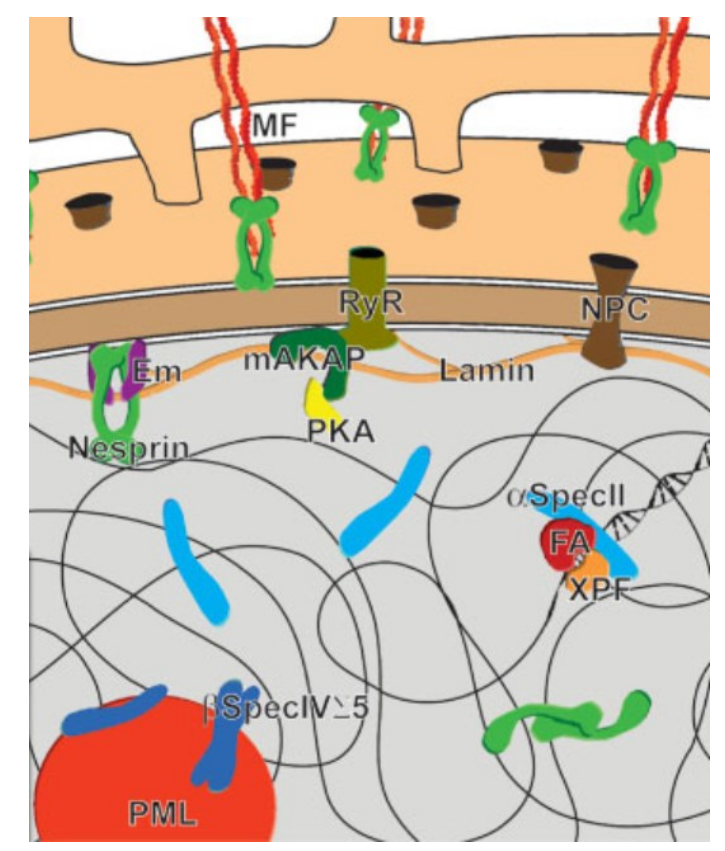

4. ábra Spektrinszerü fehérjék a sejtmagban (Young és Kothary, 2005).

\subsubsection{Az ERM fehérjék}

Már Batchelor és munkatársai 2003-ban kimutatták, hogy a humán Ezrin és Moesin megtalálhatók a sejtmagban, ugyanakkor magi funkciójuk ekkor még tisztázatlan maradt (Batchelor és mtsai, 2003). Később, a Drosophila Moesin (Moe) vizsgálata kapcsán lett világos, hogy az ERM fehérjék részt vesznek az mRNP komplexek sejtmagból történő kiszállításában (Kristó és mtsai, 2017).

Az ERM fehérjecsalád tagjai (Ezrin, Radixin, Moesin) között evolúciósan konzervált, nagyfokú hasonlóság figyelhető meg. Az ERM fehérjék jelentőségét jelzi, hogy alacsonyabbrendü élőlényekben (csalánozók, fonálférgek, ízeltlábúak) is megtalálhatók (Fiévet és mtsai, 2006). A fehérjék a 4.1 szupercsaládba tartoznak, melyeknek közös sajátságuk, hogy rendelkeznek egy megközelítőleg 300 aminosavból álló FERM doménnel (Four-point-one, Ezrin, Radixin, Moesin). A FERM-domén három alegységből épül fel, melyek együtt egy lóhere alakú struktúrát alakítanak ki. A domén szerkezeti hasonlóságot mutat az ubiquitinnel és az acyl-CoA kötő fehérjével (Fiévet és mtsai, 2006). Az ERM fehérjéket az N-terminális FERM doménen kívül a fehérjék középső részén található alfa helikális szerkezettel rendelkező flexibilis régió, valamint egy C-terminális, F-aktint kötő 
domén építi fel (5. ábra) (Maniti és mtsai, 2012). Közös tulajdonságuk továbbá, hogy kétféle térszerkezeti állapotban, egy zárt, inaktív és egy nyitott, aktív konformációban fordulnak elö. A zárt térszerkezetet a fehérjék FERM- és aktinkötő doménjei között kialakuló kölcsönhatás biztosítja. A terminális doméneken keresztül megvalósuló kapcsolat ugyanakkor lehetőséget biztosít az ERM fehérjék dimerizációjára is. Így elmondható, hogy az inaktív konformációs állapot intra- és intermolekuláris kölcsönhatások eredményeképpen is kialakulhat (5. ábra) (Clucas és Valderrama, 2014).

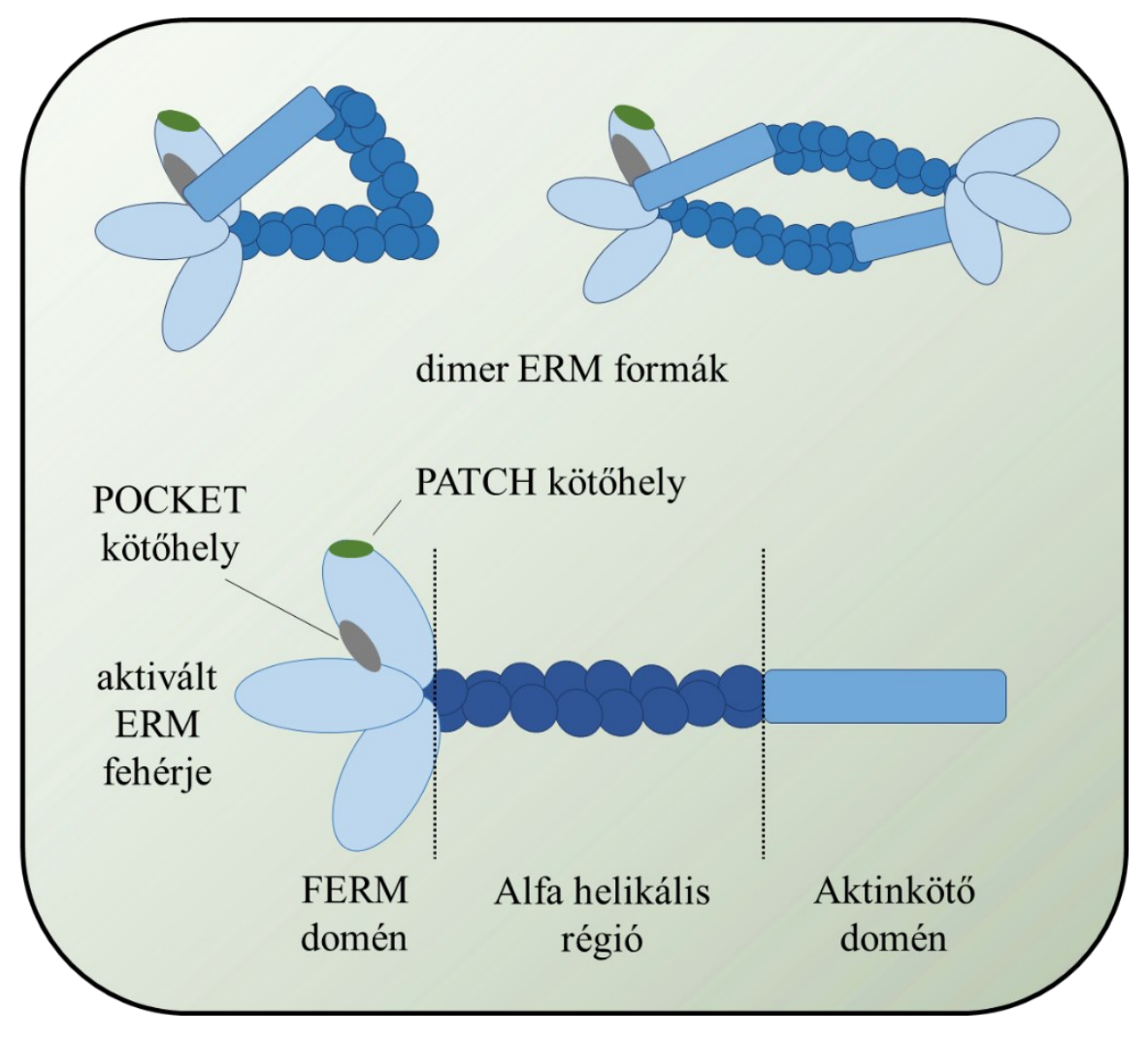

5. ábra Az ERM fehérjék szerkezete.

Az ERM fehérjék aktivációja, és az ennek során bekövetkező térszerkezeti változások jól ismertek (Ben-Aissa és mtsai, 2012). Az aktiváció első lépéseként az ERM fehérjék megkötik a membránba ágyazott fosztatidil-inozitol-4,5-biszfoszfátot $\left(\mathrm{PIP}_{2}\right)$. A kötésért a FERM harmadik alegységében található, úgynevezett PATCH (Drosophila Moesin esetében a 254-255., és 263-264. lizin) régió a felelős (5. ábra). Az aktiválódás további lépéseként a $\mathrm{PIP}_{2}$ és $\mathrm{PATCH}$ régió között fennálló gyenge kölcsönhatás megszünésével a $\mathrm{PIP}_{2}$ áthelyeződik a szintén FERM doménen található, ún. POCKET (Drosophila Moesin esetében 61., 64. és 279. lizin) kötőhelyre. A POCKET-PIP 2 között 
létrejött erős kötődés a fehérjék aktív, nyitott konformációját eredményezi, mely a Cterminális aktinkötő doménben található treonin (Drosophila Moesin esetén 559. treonin) foszforilálódásával stabilizálódik (6. ábra). Az evolúciósan konzervált treonin aminosav foszforilálását a Polo kináz-kináz 1 (slik) végzi.

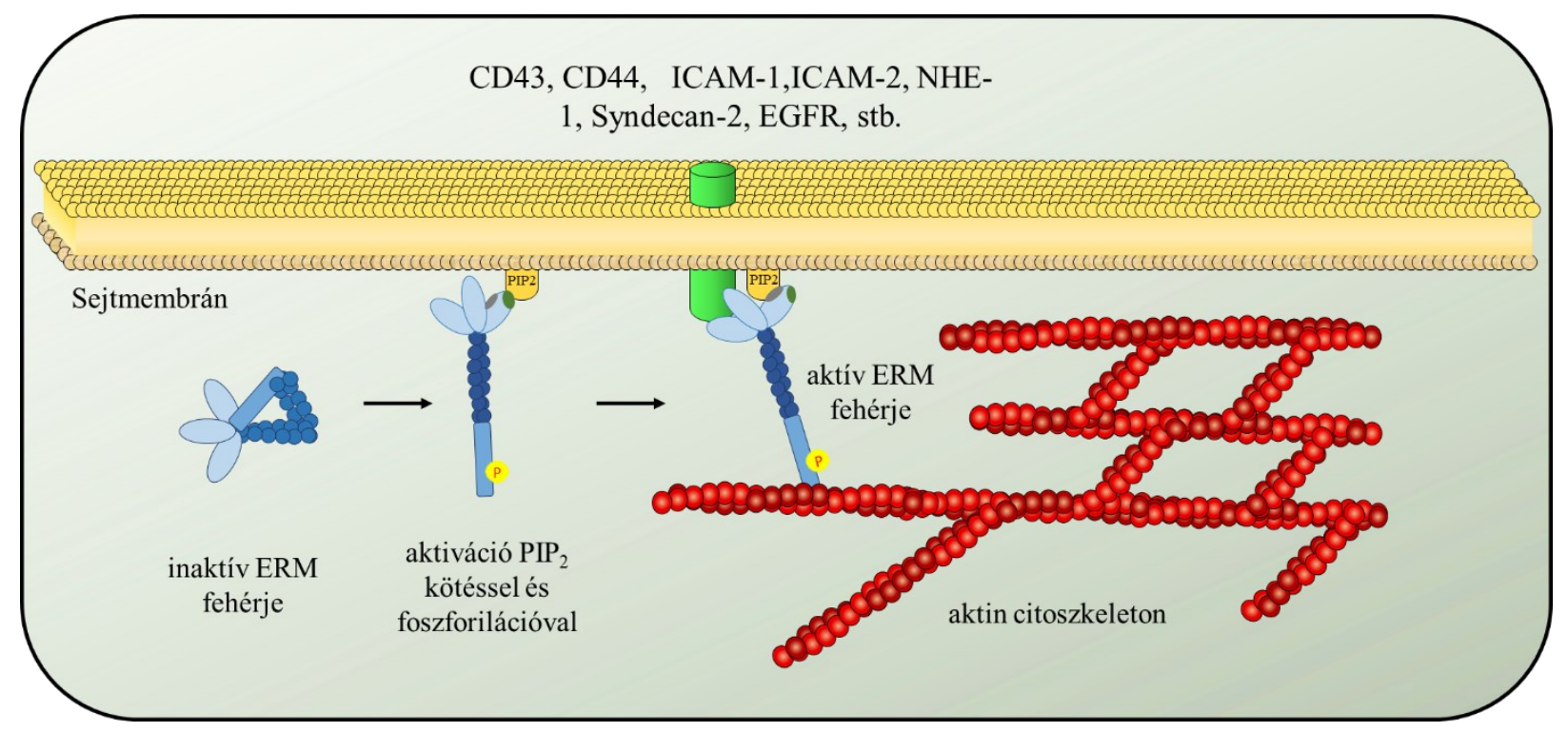

\section{6. ábra Az ERM fehérjék aktivációja.}

Az ERM fehérjék közötti nagymértékű hasonlóság föként a FERM- és az aktinkötő doménekre korlátozódik (7. ábra). A tagok között fennálló nagyfokú hasonlóság tényét tovább erősíti az a megfigyelés is, hogy az egyes ERM fehérjék bizonyos funkcióikban átfednek (Louvet-Vallée, 2000) egymással.

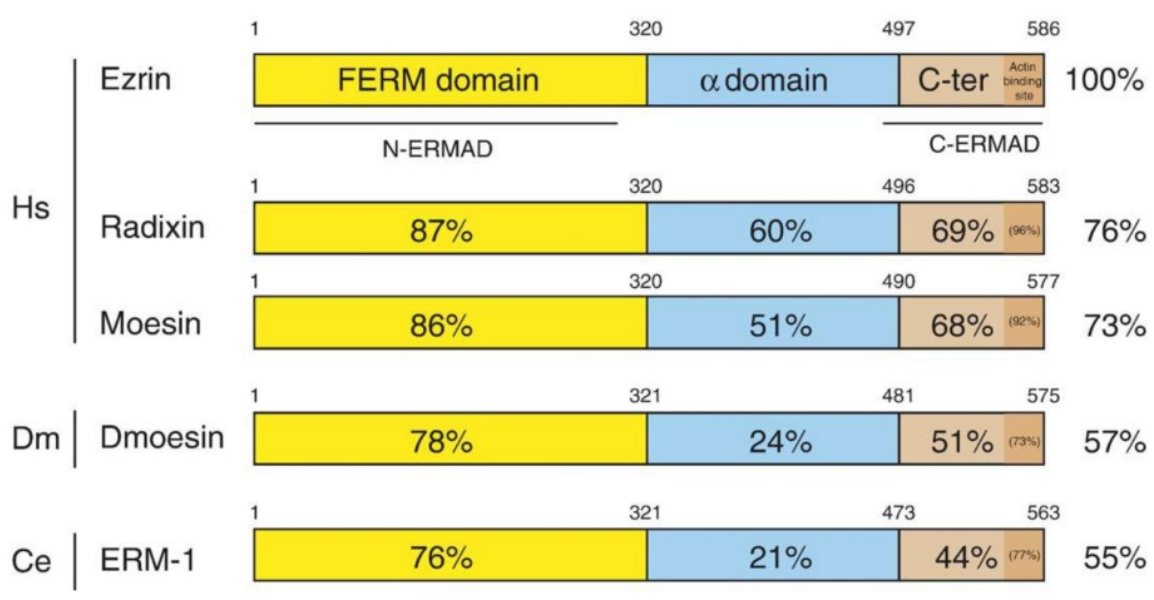

7. ábra Az ERM fehérjék doménjei közti hasonlóság mértéke.

Hs: Homo sapiens, Dm: Drosophila melanogaster, Ce: Caenorhabditis elegans

(Fiévet és mtsai, 2006). 
Az ERM fehérjék fö funkciója a sejtek membránja alatt húzódó sejtkortex szervezésében nyilvánul meg. Az aktivált fehérjék az aktinkötő- és FERM-doménjeik révén keresztkötéseket képesek kialakítani az aktin citoszkeleton és a sejtmembrán számos fehérjéje között. Ebböl következően fontos szereppel bírnak a különféle jelátviteli útvonalakban, valamint intenzív citoszkeletális átrendeződésekkel járó folyamatokban (McClatchey, 2014).

\subsection{A Drosophila Moesin fehérje}

Az ERM fehérjék kutatásában az ecetmuslica ideális modellszervezet, mivel a Drosophilában a családnak mindössze egyetlen képviselője található meg. Az egyes fajokból származó ERM fehérjék szekvenciáinak összehasonlításai azt mutatják, hogy a Drosophila egyetlen ERM fehérjéje az emlös ERM fehérjék mindhárom képviselőjével hasonlóságot mutat (7. ábra). Az emlősök Moesin fehérjéinek sajátossága azonban az alfa helikális rész és az aktinkötő domén között elhelyezkedő, prolinban gazdag régió hiánya, mely szakasz a Drosophila ERM fehérjében sem található meg. Ennek megfelelően nevezték el a muslica ERM fehérjét Moesinnek (Polesello és mtsai, 2002).

A Drosophila Moesint kódoló gén a Drosophila X kromoszómáján a 8B4-8B6 citológiai pozícióban található. A gén 14 exonból áll, melyekről 13 mRNS változat íródik át, s amelyekről 7 különböző fehérje képződik. Az egyes izoformák szekvenciáinak illesztése során megállapítható, hogy a különbségek föként a transzkriptek 5' és 3' végét, illetve a fehérjeváltozatok N-terminális részét érintik.

A moesin gén Drosophilában már az egyedfejlődés korai szakaszában kifejeződik, hiánya letalitást okoz. A Moesin megfelelő müködése nélkülözhetetlen a petesejt aktin hálózatának épségéhez és megfelelő müködéséhez, így ezáltal többek között az oskar mRNS megfelelö lokalizációjához is (Polesello és mtsai, 2002; Jankovics és mtsai, 2002). Az oskar mRNS egy anyai hatású faktor, mely fontos szereppel bír a petesejt anterior-poszterior tengelyének a kialakításában, valamint az ivarsejtek fejlődésében. A Moesin citoplazmatikus funkcióinak sérülése esetén, a normál körülmények között a poszterior póluson jellegzetes félhold alakban elhelyezkedő oskar mRNS a vad típustól eltérő, szétterjedt, illetve a poszterior pólustól távol eső lokalizációs mintázatot mutat.

A fehérje legnagyobb mennyiségben a citoplazmában, főleg a sejtkéreg területén található, de az utóbbi években végzett kutatások megállapították, hogy a Moesin a sejtmagban is jelen van. A Moesin sejtmagi jelenlét passzív elhatárolódás eredményeként, a 
mitózis végén bekövetkező magmembrán újjászerveződés során alakul ki (Vilmos és mtsai, 2016). A sejtmagba záródott Moesin az interfázis alatt részt vesz az mRNP komplexek sejtmagból történő kiszállításában, melyre bizonyítékként szolgál az, hogy kolokalizál a Rae1 és pABP mRNS export fehérjékkel az mRNP komplexekben. Illetve az mRNS exportban szerepet játszó nup98 és rael gének csendesítése esetén a Moesin magi halmozódása figyelhető meg, míg a moesin RNS interferenciával történő csendesítése az mRNS-ek magi felhalmozódását okozza (Kristó és mtsai, 2017).

\section{A citoszkeletális fehérjék sejtmagi funkcióinak vizsgálata}

A citoszkeletális fehérjék sejtmagi szerepéről nyert ismereteink főként biokémiai megközelítések eredményei, így a sejtmagi funkcióik élettani jelentőségéről csak közvetett adataink vannak. Más fajokhoz hasonlóan a Bloomingtoni Drosophila törzsközpontból beszerezhető mutáns és RNSi Drosophila törzsek nem alkalmasak a citoszkeletális fehérjék sejtmagi aktivitásának vizsgálatára, mert ezen vonalak esetében a vizsgált fehérjék citoplazmatikus funkciói éppúgy sérülnek, mint a sejtmagiak. Úgy gondoljuk azonban, hogy a jelen dolgozatban leírt, általunk kidolgozott módszer és létrehozott Drosophila vonalak lehetővé teszik az ERM fehérje, a Moesin sejtmagi aktivitásának a citoplazmatikus funkcióitól elkülönített, in vivo vizsgálatát. Ezek használatával sikerült arra a kérdésre választ kapnunk, hogy mi a jelentősége a Moesin sejtmagi jelenlétének. 


\section{ANYAGOK ÉS MÓDSZEREK}

\subsection{Drosophila melanogaster keresztezések és módszerek}

A Drosophila törzseket normál táptalajon, $25{ }^{\circ} \mathrm{C}$-on tartottuk fenn. A moe[NES]DsRed mutáns vonalak létrehozásához használt $w^{1118} ; \operatorname{PBac}\{y[+\operatorname{mDint} 2]=v a s-$ Cas9\} VK00027 (No. 51324) törzset a Bloomingtoni Drosophila törzsközpontból szereztük be. A DsRed markergén eltávolításához használt $\mathrm{prn}^{t s}, w^{+} ; \mathrm{hs}(\mathrm{Cre}), \mathrm{CyO} / \mathrm{hs}(f l i p), \mathrm{Sco}$ törzs, illetve az $\mathrm{X}^{\wedge} \mathrm{X} / \mathrm{Y} ;+/+$; $\operatorname{RecA-B/TM6,Sb}$ genotípusú, kapcsolt X kromoszómát hordozó alaptörzs Sipos László (SZBK) laboratóriumából származott. A CRM1 transzportútvonal épségét célzó vizsgálatokhoz használt $w^{1118}$; PBac\{Med-GFP.FLAG\} VK00037 (No. 42278) vonalat a Bloomingtoni törzsközpontból rendeltük. Az oskar mRNS valamint a Staufen fehérje lokalizációjának tanulmányozásához használt oskarMS,MS2-GFP/TM3 és $w, \mathrm{P}\{w+$,matTub4:GFP-Staufen $\} ; \operatorname{stau}[\mathrm{D} 3] / \mathrm{CyO}$ törzseket Daniel St Johnstontól (University of Cambridge, UK) kaptuk. A genitália rotáció jellegének meghatározásához használt UASp $>$ MoeKN/TM3,Sb,Ser, illetve az UASp $>M_{\text {MoeT }}{ }_{559}$ A és az UASp $>M_{\text {MoeT }}{ }_{559}$ D törzsek François Payre (Paul Sabatier Université, Toulouse, Franciao.) laboratóriumából származnak. A Vasa fehérje lokalizációjának tanulmányozásához használt +/+; vasaAIDGFP; +/+ törzs, valamint a transzpozonok vizsgálatához használt UAS $>$ Dcr-2(X),hs-hid(Y); NGT-Gal4; nos $>$ Gal4-VP16,nos $>$ NLS-GFP_lacZ-vas-3'UTR_burdock-target [attP2]/TM3, Ser és az UAS $>$ Dcr-2(X),hs-hid(Y); NGT-Gal4-VP16; nos>GFP_lacZ_HetA/Ser, és UAS$\operatorname{sovRNSi[3-2]~törzseket~Erdélyi~Miklós~laboratóriuma~bocsátotta~rendelkezésünkre.~A~}$ moe[NES] mutáció validálásához és jellemzéséhez használt általunk előállított UAS törzsek a következők voltak: UASp $>$ Moe-Venus, UASp $>$ Moe-V5, UASp $>$ Moe-HA, UASt $>$ MoeNES-GFP/TM3. Az UAS promóterek meghajtásához az act $5 C>$ Gal4/CyO-GFP törzset használtuk, melyet a Bloomingtoni Drosophila törzsközpontból beszerezhető $y^{l} w^{*} ; P\{A c t 5 C-G A L 4\} 25 F O 1 / C y O, y^{+}$(No. 4414) genotípusú vonalból állítottunk elő a balanszer kromoszóma lecserélésével. A moesin allélok teszteléséhez a moe[PG26]/FM0 moesin null mutáns törzset használtuk, melyben a Gal4 forrás kifejeződését a moesin promótere szabályozza. A törzset François Payre bocsátotta a rendelkezésünkre. A moe[NES] legyekben megjelenő fenotípusok hátterének meghatározásához a kapcsolt $\mathrm{X}$ kromoszómákat tartalmazó moe[NES] törzsben jelenlévő Y kromoszómát lecseréltük a moesin gént és környezetét transzlokáció formában tartalmazó Y kromoszómára. A 
keresztezéshez használt $D p(1 ; Y) 619, y[+] B[S] / w[1]$ oc [9]/C(1)DX, y[1]f[1] (No. 108358) törzset a Kyotoi Drosophila törzsközpontból szereztük be.

\subsubsection{A moe[NES]DsRed mutáns vonalak létrehozása}

A mutáns generálásához az elkészített donor konstruktot a guide RNS-ekkel (gRNS) együtt injektáltuk w; vasa>Cas9/TM6,Tb genotípusú embriókba. Az injektált elegyben az egyes komponensek koncentrációi a következők voltak: donor konstrukt $=556,67 \mathrm{ng} / \mu 1$, Cas9_2 gRNS $=149,083 \mathrm{ng} / \mu 1$, Cas9 $3 \mathrm{gRNS}=142,4 \mathrm{ng} / \mu 1$. A donor konstrukt és a gRNSek injektálásához 30 perces, $25^{\circ} \mathrm{C}$-on, sötétben történő petéztetést követően összegyüjtöttük az embriókat. Következö lépésként az embriókat 2,5 percig hipóban dekorionáltuk, majd agarkockán ecsettel egymás mellé sorba rendeztük. Ezután heptános ragasztóval bevont fedőlemezre áthelyeztük az embriókat, végül Voltalef olajjal lefedtük. Az embriókat mikroszkóp alatt, $18{ }^{\circ} \mathrm{C}$-on, kapilláristűvel injektáltuk. Az injektálás után 24 órával a lárvákat normál Drosophila táptalajra helyeztük. A kikelő legyeket FM6w- balanszer kromoszómát hordozó hímekkel kereszteztük (8. ábra). A donor konstrukt beépülésének nyomon követését a vektoron jelenlévő, eltávolítható, a szemben piros fluoreszcenciát okozó markergén (DsRed) tette lehetővé.

$$
\begin{aligned}
& \frac{w^{1118}}{w^{1118}} ; \frac{\text { vasa }>\text { Cas } 9}{T M 6, S b} \otimes \frac{w^{1118}}{Y} ; \frac{\text { vas } \rightarrow \text { Cas } 9}{T M 6, S b} \\
& \text { Injektálás } \\
& \frac{w^{1118}}{w^{1118} \text { moe }[\text { NES }] \text { DsRed }} ; \frac{\text { vasa }>\text { Cas } 9}{T M 6, S b} \otimes \frac{F M 6 w^{-}}{Y} ; \frac{+}{+} \\
& \frac{\downarrow}{w^{1118} \text { moe }[N E S] D s R e d} ; \frac{+}{F M 6 w^{-}} ; \frac{1}{T M 6, S b} \otimes \frac{F M 6 w^{-}}{Y} ; \frac{+}{+}
\end{aligned}
$$

\section{8. ábra A moe[NES]DsRed vonalak megalapítása.}

A moe[NES]DsRed törzs megalapításához a piros fluoreszcensen világító szemü nőstényeket $\left(w^{1118} / w^{1118}\right.$, moe [NES]DsRed; vasa>Cas9/TM6,Sb) kereszteztük FM6w ${ }^{-}$ balanszer kromoszómát hordozó hímekkel a törzs megalapításához. 


\subsubsection{A DsRed markergén eltávolítása}

A moe[NES]DsRed/FM6w- vonalak megalapítását követően a szemspecifikus kifejeződést biztosító 3PX3 promóterrel szabályozott DsRed markergént helyspecifikus rekombináció segítségével eltávolítottuk. A marker eltávolításához a $p r n^{\text {ts }}, w^{+}$; hs(Cre),CyO/hs(flip),Sco törzset használtuk. Azokban a hímekben illetve nőstényekben, melyek egyszerre hordozták a moe[NES]DsRed, valamint a Cre rekombináz génjét, a markergént a $25{ }^{\circ} \mathrm{C}$-on is kifejeződő Cre rekombináz eltávolította. Ezekből az állatokból az FM6 $w^{-}$balanszer kromoszómát tartalmazó hímekkel, illetve nőstényekkel történő keresztezéssel két lépésben stabil törzseket alapítottunk (9. ábra).

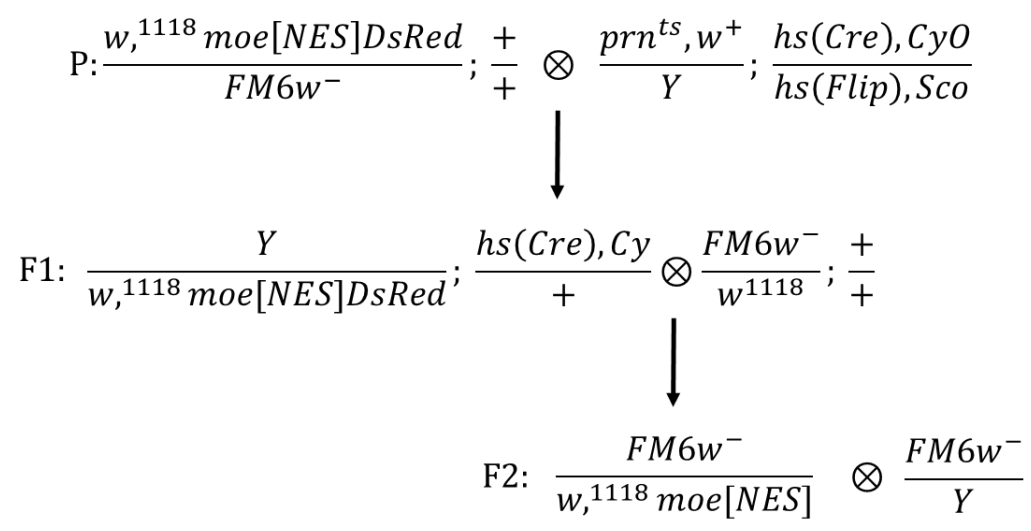

9. ábra A DsRed markergén eltávolítása.

A markergén eltávolításához azokat a hímeket, melyek egyszerre hordozzák a moe [NES]DsRed, valamint a Cre rekombináz géneket $\left(w^{1118}\right.$, moe $[\mathrm{NES}] D s R e d / \mathrm{Y}$; $h s(\mathrm{Cre}), \mathrm{CyO} /+)$, kereszteztük FM6w- balanszer kromoszómát tartalmazó nőstényekkel.

\subsubsection{A kapcsolt X kromoszómákat tartalmazó moe[NES] vonalak létrehozása}

A kapcsolt X kromoszómákat tartalmazó törzsek alkalmazása lehetővé teszi a domináns anyai hatással bíró mutációk fenntartását. A nőstények két, fizikailag összekapcsolt $\mathrm{X}$, és egy $\mathrm{Y}$ kromoszómát tartalmaznak $\left(\mathrm{X}^{\wedge} \mathrm{X} / \mathrm{Y}\right)$. Ezekben a vonalakban a hím utódok az Y kromoszómát az anyjuktól, míg az X kromoszómát az apjuktól kapják. Ennek megfelelően, a moe[NES]DsRed és a Cre rekombináz géneket hordozó hímet kereszteztük a X^X/Y;+/+; RecA-B/TM6,Sb nőstényekkel (10. ábra). 


$$
\begin{aligned}
& \mathrm{P}: \frac{w^{1118} \text { moe }[N E S] D s R e d}{F M 6 w^{-}} ; \frac{+}{+} ; \frac{+}{+} \otimes \frac{\operatorname{prn}^{t s}, w^{+}}{Y} ; \frac{h s(\text { Cre }), C y O}{h s(\text { flip }), S c o} ; \frac{+}{+} \\
& \mathrm{F} 1: \frac{w_{1}^{1118}[\text { moeNES }] \text { DsRed }}{Y} ; \frac{\mathrm{hs}(\mathrm{Cre}), \mathrm{CyO}}{+} ; \frac{+}{+} \otimes \frac{\hat{\mathrm{XX}}}{\mathrm{Y}} ; \frac{+}{+} ; \frac{\operatorname{RecA}-\mathrm{B}}{\mathrm{TM} 6, \mathrm{Sb}} \text { 우 } \\
& \downarrow \\
& \mathrm{F} 2: \frac{w_{1}^{1118} \text { moeNES }}{\mathrm{Y}} ; \frac{+}{+} ; \frac{+}{\mathrm{TM} 6, \mathrm{Sb}} \otimes \frac{\hat{\mathrm{XX}}}{\mathrm{Y}} ; \frac{+}{+} ; \frac{+}{\mathrm{TM} 6, \mathrm{Sb}} \text { 우 } \\
& \downarrow \\
& \frac{w,{ }^{1118} \operatorname{moe}[N E S]}{\mathrm{Y}} ; \frac{+}{+} ; \frac{+}{+}
\end{aligned}
$$

\section{0. ábra Kapcsolt $X$ kromoszómákat tartalmazó moe[NES] vonalak létrehozása.}

A DsRed eltávolításához, azokat a hímeket, melyek egyszerre hordozzák a moe [NES]DsRed, valamint a Cre rekombináz géneket ( $w^{1118}$, moe $[\mathrm{NES}] D s R e d / \mathrm{Y}$; hs(Cre),CyO/+), kereszteztük a kapcsolt X kromoszómákat hordozó nőstényekkel.

\subsubsection{A moe[NES] mutáns legyek élettani jellemzése}

\subsubsection{A letalitás vizsgálata}

A letalitás meghatározásához az állatokat mindig $25^{\circ} \mathrm{C}$-on, inkubátorban tartottuk.

\section{Embrionális letalitás}

A $w^{1118}$ és moe $[\mathrm{NES}] / m o e^{\mathrm{G} 0415}$ egykorú nőstényeket kereszteztünk $w^{1118} /$ Y hímekkel, majd a nőstényeket szinkronizáltan petéztetőcsőben petéztettük. Az embriókat 100-as csoportokban a táptalajon sorba rendeztük, majd megszámoltuk a kikelt lárvákat, valamint a korán (fehér) és későn (barna) elpusztult petéket.

\section{Lárvális letalitás}

A $w^{1118} / m_{0} e^{\mathrm{G} 0415}$ és $m o e[\mathrm{NES}] / m o e^{\mathrm{G} 0415}$ genotípusú, azonos életkorral rendelkező nőstényeket $w^{1118} / Y$ hímekkel kereszteztük. A szinkronizált petéztetést követően a frissen kikelő lárvákból 20-20 darabot friss táptalajra helyeztünk, majd följegyeztük, az L3 stádiumig eljutott lárvák, illetve a bábok és a kikelt egyedek számát. 


\subsubsection{2. Élethossz vizsgálat}

Azonos korú $m o e^{\mathrm{G} 0415} / m o e[\mathrm{NES}]$, moe $[\mathrm{NES}] / w^{1118}$ és $m o e^{\mathrm{G} 0415} / w^{1118}$ nőstényeket, valamint $m o e[\mathrm{NES}] / \mathrm{Y}$ és $w^{1118} / \mathrm{Y}$ hímeket gyüjtöttünk, majd kisebb csoportokban friss táptalajra helyeztük őket. Minden nap meghatároztuk az elpusztult állatok számát, és az élő legyeket friss táptalajra tettük. Az élethossz vizsgálatokat három hőmérsékleten, $18{ }^{\circ} \mathrm{C}$-on, $25{ }^{\circ} \mathrm{C}$-on, és $29{ }^{\circ} \mathrm{C}$-on végeztük.

\subsubsection{A moe[NES] mutánsok éhezési stressz türése}

Azonos korú $m o e^{\mathrm{G} 0415} / m o e[\mathrm{NES}]$, moe $[\mathrm{NES}] / w^{1118}$ és $m o e^{\mathrm{G} 0415} / w^{1118}$ nőstényeket egyenként kettő darab $w^{1118} / Y$ hímmel kereszteztük. A legyeket minden nap friss táptalajra helyeztük, majd megszámoltuk az előző nap lerakott petéket. A 4. és az 5. nap az állatokat élesztőmentes táptalajra ( $1 \%$ agar, 0,5\% propionsav - foszforsav (9:1), 5\% szukróz) helyeztük, majd a 6. napon ismételten normál táptalajon tartottuk őket, amikor is meghatároztuk az előző nap lerakott peték számát. Ezután mindig friss táptalajra helyeztük a legyeket, és 10 napon át számoltuk a lerakott petéket.

\subsubsection{A moe[NES] mutáns nöstények petehozama}

Azonos korú nőstényeket (moe $e^{\mathrm{G} 0415} / m o e[\mathrm{NES}]$, moe $[\mathrm{NES}] / w^{1118}$ és $\left.m o e^{\mathrm{G} 0415} / w^{1118}\right)$ egyenként kereszteztünk be kettő darab $w^{1118} / Y$ hímmel. A legyeket minden nap friss táptalajra tettük, majd 12 napon keresztül számoltuk a petéket.

\subsubsection{A moe[NES] mutánsok mászóképessége}

Az egyidős $w^{1118} / Y$ és moe[NES]/Y hímeket centiméter skála mellett hengerben mászattuk, majd meghatároztuk azon legyeknek a számát, melyek képesek voltak 8 másodperc alatt a 15 centiméteres távot megtenni (Manilja és Hasan, 2018).

\subsubsection{Transzpozonok szabályozásának vizsgálata petefészekben}

A moe[NES]/Y, illetve a pozitív kontrollnak használt UAS-sovRNSi[3-2]; nos $>$ Gal4 hímeket a Burdock (nosGal4-VP16, nos>NLS_GFP_lacZ_vas-3'UTR_burdock-target [attP2]/TM3,Ser), illetve HetA (NGT-Gal4-VP16; nos $>$ GFP_lacZ_HetA/Ser) szenzorokat kifejező nőstényekkel kereszteztük be, majd az utódok petefészkein X-gal festést végeztünk. 


\subsubsection{Mellékhatások kizárása}

\subsubsection{A CRM1 útvonal épségének ellenörzése}

A CRM1 transzportútvonal épségét célzó vizsgálatokhoz a $w^{1118} ;$ PBac $\{M e d-$ GFP.FLAG $\}$ vonalat használtuk. A nőstényeket moe[NES]/Y illetve $w^{1118} / Y$ hímekkel kereszteztük. Ezt követően vizsgáltuk a heterozigóta nőstények utódainak dajkasejtjeiben a Medea-GFP (Med-GFP) fehérje sejtmag/citoplazma intenzitási arányának különbségét.

\subsubsection{Citoplazmatikus funkciók épségének ellenörzése}

Az oskar mRNS lokalizációjának vizsgálata

Az oskar mRNS lokalizációjának tanulmányozásához használt oskarMS,MS2GFP/TM3 törzsben a transzgenikus oskar mRNS-éhez hozzáépítették a virális eredetü MS szekvenciát, melyhez az MS2-GFP fehérje specifikusan kapcsolódik. Az oskarMS,MS2GFP/TM3 genotípusú nőstényeket moe[NES]/Y illetve $w^{1118} / \mathrm{Y}$ genotípusú hímekkel kereszteztük. Ezt követően vizsgáltuk a moe[NES]/+; oskarMS,MS2-GFP/+, valamint $w^{1118} /+$; oskarMS,MS2-GFP/+ utódok petefészkeiben az oskarMS mRNS lokalizációját. Az oskarMS,MS2-GFP/TM3 legyek első kromoszómáját lecserélve létrehoztuk a $m o e^{\mathrm{G} 0415} / \mathrm{FM} 7 \mathrm{c}$; oskarMS,MS2-GFP/TM3 törzset. A moe $e^{\mathrm{G} 0415}$ egy recesszív letális null allél, míg a moe $e^{E P 1652}$ egy hipomorf moesin allél, amelyekben egy-egy P-elem található. Ezeket a törzseket keresztezve is elvégeztük a fent említett kísérletet. Az endogén oskar mRNS lokalizációjának vizsgálatát moe[NES]/moe $e^{\mathrm{G} 0415}$, és $w^{1118} / m o e^{\mathrm{G} 0415}$ nőstények petefészkeiben fluorescens in situ hibridizációs (FISH) módszerrel végeztük el. Ehhez a $m o e[\mathrm{NES}] / \mathrm{Y}$, és a $w^{1118} / \mathrm{Y}$ hímeket $m o e^{\mathrm{G} 0415} / \mathrm{FM} 7 \mathrm{c}$ nőstényekkel kereszteztük be.

\section{A Vasa fehérje lokalizációjának vizsgálata petefészekben illetve embriókban}

A kísérletek során a vasaAID-GFP (2. kr.) nőstényeket kereszteztük moe[NES]/Y, illetve $w^{1118} / Y$ hímekkel. Ezt követően a nőstény utódok petesejtjeiben vizsgáltuk az endogén Vasa-GFP lokalizációt. A Vasa fehérje embriókban történő vizsgálatához az előbbiekben leírt keresztezés utódait petéztettük 1 órán keresztül. A petéztetést követően azonnal vizsgáltuk a Vasa fehérje eloszlását.

\section{A Moesin-NES fehérje aktivációjának és lokalizációjának vizsgálata}

Az aktivációs és lokalizációs kísérleteket moe $[\mathrm{NES}] / m o e^{\mathrm{G} 0415}$ és $w^{1118} / m o e^{\mathrm{G} 0415}$ nőstények petefészkein végeztük el. 


\subsection{6. Élő petefészkek vizsgálata mikroszkóppal}

A legyeket PBS $\left(137 \mathrm{mM} \quad \mathrm{NaCl}, 2,7 \quad \mathrm{mM} \quad \mathrm{KCl}, 10 \mathrm{mM} \quad \mathrm{Na}_{2} \mathrm{HPO}_{4}\right.$,

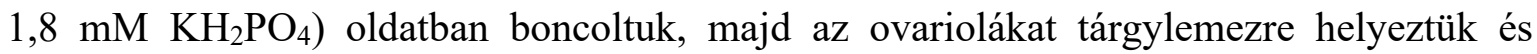
Drosophila Schneider's tápoldatban (Lonza, Schneider's Drosophila Medium, Modified, 04351Q) fedőlemezzel lefedtük. Az elkészült mintákat Olympus konfokális mikroszkóppal vizsgáltuk (Olympus Fluoview FV1000 Confocal Microscope, 40x olajimmerziós objektív, $1.3 \mathrm{NA})$.

\subsection{7. Élő Drosophila embriók vizsgálata mikroszkóppal}

A mikroszkópos vizsgálathoz 60 percig $25{ }^{\circ} \mathrm{C}$-on, sötétben történő petéztetést követően összegyüjtöttük az embriókat. Következö lépésként 2,5 percig az embriókat hipóban dekorionáltuk, majd agarkockán ecsettel egymás mellé sorba rendeztük. Ezután fedőlemezre áthelyeztük az embriókat, Voltalef olajjal lefedtük, és az így elkészített mintákat Olympus (Olympus IX83 Spinning Disk Confocal Microscope, 20x olajimmerziós objektív, $0.45 \mathrm{NA}$ ) mikroszkóppal vizsgáltuk. Az embriókban mérhető fluoreszcencia intenzitás görbéit anterior-poszterior irányban, a középvonal mentén vettük föl az ImageJ programmal. Az intenzitás görbékhez tartozó értékek statisztikai kiértékelését az Origin86 szoftver alkalmazásával végeztük el.

A poláris sejtek lefüződésének folyamatát, Olympus (Olympus IX83 Spinning Disk Confocal Microscope, 60X olajimmerziós objektív, 0.45 NA) mikroszkóppal vizsgáltuk. A poszterior pólus vizsgálatához az embriókat üvegaljú petricsészébe (Cellvis, $20 \mathrm{~mm}$ Glass bottom dishes, D35-20-1-N) helyeztük, majd Voltalef olajjal lefedtük. Az egyes embriókról készített videók az ImageJ programmal készültek az optikai szeletek összefüzésével.

\subsubsection{Petefészkek preparálása és immunfestése}

A nőstényekből PBS oldatban kiboncolt petefészkeket 4\%-os paraformaldehid-PBS oldatban fixáltuk 20 percig $25^{\circ} \mathrm{C}$-on. Ezután a petefészkeket PBS-ben részlegesen ovariolákra szedtük szét, majd PBT (PBS $+0,1 \%$-os Triton-X) oldatban forgatva 2x30 percig mostuk $25^{\circ} \mathrm{C}$-on. A minták blokkolása 1,5 ml-es kupakos centrifuga csőben forgatva, $25^{\circ} \mathrm{C}$-on történt, 1 órán át PBT-N-ben (PBT, 1\% BSA, 5\% FCS). Ezt követően az elsődleges ellenanyaggal a mintákat $4{ }^{\circ} \mathrm{C}$-on, egy éjszakán át inkubáltuk. A használt ellenanyagok és 
hígításaik a következők voltak: anti-GFP 1:500 (Thermo Fisher Scientific, A6455), antifoszfo ERM 1:200 (Cell Signaling Technology, 3141), anti-vasa 1:200 (DSHB, 760351), anti-HTS (1B1) (DSHB, 528070). Ezt követően a mintákat 2x30 percig mostuk PBT oldatban forgatva $25{ }^{\circ} \mathrm{C}$-on, majd 2 órán keresztül inkubáltuk sötétben a másodlagos ellenanyagokkal. A következő másodlagos ellenanyagokat használtuk a kísérleteink során: anti-rabbit Alexa Fluor 488 1:600 (Thermo Fisher Scientific, A11008), anti-rat Alexa Fluor 647 (Thermo Fisher Scientific, A21247), anti-mouse Alexa Fluor 546 (Thermo Fisher Scientific, A11030). A másodlagos ellenanyaggal együtt a DNS-jelöléshez PBT-N-ben oldott DAPI festéket (Sigma-Aldrich, D9564; végkonc. 0,2 $\mu \mathrm{g} / \mathrm{ml}$ ), valamint a filamentáris aktin jelöléséhez Phalloidin Alexa Fluor 546-ot (1:40) (Thermo Fisher Scientific, A22283) alkalmaztunk. A sejtmembrán jelölésére Wheat Germ Agglutinin (WGA) Alexa Fluor 647et (Thermo Fisher Scientific, W32466) használtuk. A PBS-ben történő WGA festést (1:500) a PBT-N-ben történő blokkolás előtt végeztük 45 percig, $25^{\circ} \mathrm{C}$-on. A másodlagos ellenanyaggal történő reakciót követően a mintákat 2x30 percig forgatva mostuk PBT oldatban. Végül az ovariolákat tárgylemezre helyeztük és beágyazó médiummal (Fluoromount G, Thermo Fisher Scientific, 00-4958-02) lefedtük.

\subsubsection{Hősokkolt nyálmirigyek preparálása és immunfestése}

A nyálmirigyeket PBS-ben, 3. fejlődési stádiumban lévő lárvákból boncoltuk ki, majd áthelyeztük őket Drosophila Schneider's tápoldatba (Lonza, Schneider's Drosophila Medium, Modified, 04-351Q). A mintákat tartalmazó Eppendorf csöveket vízfürdőben 37 ${ }^{\circ} \mathrm{C}$-on, 30 percen keresztül inkubáltuk hősokkolás céljából. A nyálmirigyeket ezután 4\%-os paraformaldehid-PBS oldatban fixáltuk 10 percig $25{ }^{\circ} \mathrm{C}$-on. Az immunfestés a "2.1.8. Petefészek preparálása és immunfestése" részben ismertetett módon történt. A használt elsődleges ellenanyagok és hígításaik a következők voltak: anti-GFP 1:500 (Thermo Fisher Scientific, A6455), a nyúl poliklonális Moesin ellenanyagot (1:1000) Dr. Vizler Csaba és Dr. Marton Annamária (SZBK, Biokémiai Intézet) készítette el a számunkra. A következő másodlagos ellenanyagot használtuk a kísérleteink során: anti-rabbit Alexa Fluor 488 1:600 (Thermo Fisher Scientific, A11008).

\subsubsection{Petefészkek X-gal festése}

A három napos nőstény legyeket PBS-ben boncoltuk, majd a petefészkeket $0,5 \%$ glutáraldehid-PBS-ben fixáltuk 15 percig. A mintákat 3x10 percig mostuk PBS-ben, ezt 
követően a festőoldatban (10 mM PBS, $1 \mathrm{mM} \mathrm{MgCl} 2,150 \mathrm{mM} \mathrm{NaCl}, 3 \mathrm{mM} \mathrm{K}$-ferricianid, $3 \mathrm{mM}$ K-ferrocianid, $0.1 \%$ Triton, $0.1 \% \mathrm{X}$-Gal) inkubáltuk $25{ }^{\circ} \mathrm{C}$-on transzpozon szenzoroktól függően 2 órán (Burdock szenzor), valamint éjszakán (HetA szenzor) át.

\subsubsection{Fluoreszcens in situ hibridizáció (FISH)}

A lárvákat, illetve a kifejlett nőstényeket PBS-ben boncoltuk, majd a nyálmirigyeket és a petefészket 4\%-os paraformaldehid-PBS oldatban fixáltuk 10 percig. A fixáló oldat eltávolítása után 10 perces metanolos posztfixáló lépés következett, végül 70\%-os etanolos mosással rehidratáltuk a mintáinkat. Ezt követően a nyálmirigyeket és petefészkeket $1 \mathrm{M}$ Tris- $\mathrm{HCl}(\mathrm{pH} 8.0)$ oldattal forgatva 5 percig mostuk, majd 1 órán keresztül $37{ }^{\circ} \mathrm{C}$-on inkubáltuk a hibridizációs pufferben (25\% formamide, 10\% dextrán-szulfát, $0,005 \%$ BSA, $0,001 \mu \mathrm{g} / \mu \mathrm{l}$ fluorofórral jelölt oligonukleotid próba (nyálmirigy esetén Cy3-oligo-dT (5'/5Cy3/T(30)-3'), petefészeknél oskar mRNS specifikus próba, melynek szekvenciája 5'/5Cy5/TGGCATTGGCAAAACAAATCACAGAC-3'), 2XSSC (300 mM NaCl, $30 \mathrm{mM}$ nátrium-citrát, $\mathrm{pH} 7,0$ ) oldatban). A hibridizációs lépést $2 \times 2$ perces $2 \mathrm{XSSC}$-vel történő mosás követte. A DNS jelöléséhez a DAPI festés $(0,2 \mu \mathrm{g} / \mathrm{ml} 2$ XSSC pufferben) 30 percig tartott, majd szintén $2 \times 2$ perces 2 XSSC-s mosás következett $25{ }^{\circ} \mathrm{C}$-on. Ezután a nyálmirigyeket, illetve az ovariolákat tárgylemezre helyeztük és beágyazó médiummal (Fluoromount G, Thermo Fisher Scientific, 00-4958-02) lefedtük.

\subsection{Molekuláris biológiai módszerek}

A vizsgálatainkhoz szükséges oligonukleotidok (primerek, FISH próbák) szintézisét az Integrated DNA Technologies (BioScience Kft.), valamint az SzBK oligonukleotid szintézis laboratóriuma végezte. A szekvenálás során az Eurofins és az SzBK Szekvenáló Platform szolgáltatásait vettük igénybe. A PCR reakciókat MJ Research PTC-200, valamint Thermo Scientific ARKTIK Thermal Cycler készülékeken végeztük. A kísérletek során alkalmazott KIT-eket (DNS tisztítás, illetve izolálás, klónozás, mutagén PCR, transzfekciós kit) a gyártók utasításai alapján használtuk. 


\subsubsection{A CRISPR módszer}

\subsubsection{A CRISPR gRNS-ek létrehozása és tesztelése}

A megfelelő CRISPR hasítóhelyeket a flyCRISPR Optimal Target Finder (http://targetfinder.flycrispr.neuro.brown.edu/) online program segítségével azonosítottuk és választottuk ki az elhelyezkedésük és off-target helyeik száma alapján. A kritériumoknak legjobban négy Cas9 hasítóhely felelt meg. Ezek a következők voltak:

Cas9_1 (4 db off-target, 5' - CCAATGAATATAGTCTTGATACC-3'),

Cas9_2 (6 db off-target, 5'- CCCTTATGCTCCACTCAACTAAC-3'),

Cas9_3 (0 db off-target, 5'-CCTATGTAATATACTGGAAACTT-3'), és

Cas9_4 (2 db off-target, 5'-CCAACCGCGCAACTTAAGGTAGC-3')

Ezután megszintetizáltattuk a gRNS-ek szensz és antiszensz szálait, majd elvégeztük az oligonukleotidok 5 ' végeinek foszforilálását, a komplementer szálak hibridizációját és az így kapott kettősszálú oligonukleotidok pU6-BbsI-chiRNS plazmidba építését. Az elkészített gRNS-eket páronként (Cas9_1+Cas9_3; Cas9_1+Cas9_4; Cas9_2+Cas9_3; Cas9_2+Cas9_4), $250 \mathrm{ng} / \mu 1$-es koncentrációban $w$; vasa>Cas9/TM6,Tb genotípusú embriókba injektáltuk. Az injektálás menete megegyezett a donor konstruktok és a gRNSek injektálása során ismertetett protokollal. Az injektálást követő 22 óra múlva az embriókból DNS-t izoláltunk. A konstruktokról termelődő gRNS-ek hatékonyságának teszteléséhez az injektált embriókat ötösével 1,5 ml-es, kupakos centrifuga csőbe összegyüjtve $20 \mu 1$ izoláló pufferben (10 mM Tris- $\mathrm{HCl}(\mathrm{pH} 8,2), 25 \mathrm{mM} \mathrm{NaCl}, 1,0 \mathrm{mM}$ EDTA, $0.2 \mathrm{v} / \mathrm{v} \%$ Triton X100) homogenizáltuk, majd 1 óráig $37{ }^{\circ} \mathrm{C}$-os vízfürdőben tartottuk. Ezután a homogenizátumokat $95{ }^{\circ} \mathrm{C}$-on 5 percig hőinaktiváltuk. A mintákon elvégzett ellenőrző PCR-hez Taq (5 unit/ $\mu 1$, Thermo Fisher Scientific) és Pfu DNS polimerázok (2,5 unit/ $\mu$ 1, Thermo Fisher Scientific) 20:1 arányú keverékét és a gMoeFw4 forward (5'- GCATTCAGGACGAGGTCAACG -3') + gMoeRev4 reverz (5'GCCTCTCAATCGAGATATACAACT -3') primerpárt használtuk. A PCR reakcióelegyek összetétele: 14,5 $\mu 1$ desztillált víz; $2,5 \mu \mathrm{l}$ puffer $\left(10 \mathrm{X},(\mathrm{NH} 4)_{2} \mathrm{SO}_{4}\right) ; 2,0 \mu 1 \mathrm{DNS}$ a homogenizátumból; 2,5 $\mu \mathrm{l} \mathrm{MgSO}_{4}(1,5 \mathrm{mM}$ végkoncentráció) $1,0 \mu \mathrm{l}$ dNTP (2,5 mM törzsoldatból); 1,0 $\mu$ l forward primer (5 $\mu \mathrm{M}$ törzsoldatból); $1,0 \mu$ l reverz primer $(5 \mu \mathrm{M}$ törzsoldatból); 1,0 $\mu 1$ Taq DNS polimeráz (5 unit/ $\mu 1)-P f u$ DNS polimeráz (2,5 unit/ $\mu 1)$ 20:1 arányú keverékéből (Thermo Scientific). A PCR reakció során használt program: $95{ }^{\circ} \mathrm{C}-2$ perc, $95{ }^{\circ} \mathrm{C}-30$ másodperc, $60{ }^{\circ} \mathrm{C}-1$ perc, $72{ }^{\circ} \mathrm{C}-3$ perc, $72{ }^{\circ} \mathrm{C}-3$ perc, a ciklusszám 35 volt. 


\subsubsection{A donor konstrukt megépitése}

A donor konstrukt megépítéséhez PCR reakcióval amplifikáltuk a szükséges kb. 5 kbp nagyságú moesin génszakaszt. A reakcióban Phusion High-Fidelity DNS polimerázt (Thermo Fisher Scientific, F530S) valamint a gFMoeSL2 forward (5'GCTGATCCAGGACATTACACTG-3') és gRMoeLS2 reverz (5'GATCACGCTGTGAACTCTGC-3') DNS primereket, valamint egyetlen légyből izolált genomi DNS-t használtunk. A reakcióelegy összetétele: $28,5 \mu 1$ desztillált víz; $10 \mu 1$ High Fidelity puffer, $1 \mu 1$ gDNS; 4,0 $\mu 1$ dNTP (2,5 mM törzsoldatból); 3,0 $\mu 1$ forward primer (5 $\mu \mathrm{M}$ törzsoldatból); 3,0 $\mu 1$ reverz primer (5 $\mu \mathrm{M}$ törzsoldatból); 0,5 $\mu 1$ Phusion High Fidelity DNS polimeráz. A PCR során használt program: $98{ }^{\circ} \mathrm{C}-1$ perc, $98{ }^{\circ} \mathrm{C}-15$ másodperc, 61 ${ }^{\circ} \mathrm{C}$ - 30 másodperc, $72{ }^{\circ} \mathrm{C}-4$ perc, $72{ }^{\circ} \mathrm{C}-10$ perc. A reakció során a ciklusszám 40 volt.

A keletkezett PCR terméket pJET (CloneJET PCR Cloning Kit, Thermo Fisher Scientific, K1231) vektorba építettük a gyártó útmutatásait követve. Az így létrehozott moepJET konstrukton ezután mutagén PCR segítségével megváltoztattuk a Cas9_3 hasítóhely szekvenciáját, hogy ezzel megvédjük a majdani donor konstruktot az embrióban történő Cas9 általi lebontástól. Mivel a másik gRNS felismerőhely szekvenciája a donor konstrukt összeépítése során megváltozott, ennek külön módosítása szükségtelen volt. A mutagén PCR (Quick Change II Site Directed Mutagenesis KIT, Agilent, Cat No. 200523) során a következő primereket használtuk (a genomi szekvencia módosításai pirossal jelölve): MoeCas9mut_Fw forward TAAAACAACAAAATGCCACGTTTTTATTTTATCTATATAATATACTGGAAACTT TCGACATGT-3') és MoeCas9mut_Rev (5'ACATGTCGAAAGTTTCCAGTATATTATATAGATAAAATAAAAACGTGGCATTT TGTTGTTTTA-3'). A továbbiakban ezen a módosított moe-pJET konstrukton végeztük el a donor konstrukt megépítéséhez szükséges PCR reakciókat.

A donor konstrukt megépítéséhez használt primerek 5' végére restrikciós enzimek felismerő helyeit szintetizáltattuk, melyeket a szekvenciákban kékkel jelöltünk. Az első PCR reakcióban (PCR1) használt primerek: (Fw_Moe_EcoRI) 5'CGTAGAattCATAGCTGATCCAGGACATTACACTG-3' és (Rev_Moe_NotI) 5' GGAGGCGGCCGCAGACATAAGGGACTCGATTTCGAAC -3’. A második PCR

(PCR2) során alkalmazott primerek: (Fw_Moe_SapI) 5'-
GCATGCTCTTCGTATCTCCACTCAACTAACAATATCA-3' és (Rev_NES_HindIII) 
5'ATAAAGCTTTTATGTCTTGTTGATATCAAGACCTGCTAATTTCAAGGCTAATT

CATTCATGTTCTCAAACTGATCGACG-3'. A harmadik reakcióban (PCR3) használt

primerek a következők voltak: Fw_Moe_HindIII (5'GgCGAaAgCtTAagCTAtCAAAGATCAGAGATC-3') és Rev_Moe_SapI (5'GAATGCTCTTCAGACCAATCTGTTGATGTAGGC-3'). A homológiakarok összeállításához használt három PCR reakció elegyének összetétele: 32,5 $\mu$ l desztillált víz; $10 \mu 15 X$ High Fidelity puffer, 1,0 $\mu 1$ DNS (10 ng/ $\mu 1$ törzsoldatból); 1,0 $\mu 1$ dNTP (10 mM törzsoldatból); $2,5 \mu 1$ forward primer (10 $\mu \mathrm{M}$ törzsoldatból); $2,5 \mu 1$ reverz primer $(10 \mu \mathrm{M}$ törzsoldatból); 0,5 $\mu 1$ Phusion High-Fidelity DNS polimeráz (Thermo Fisher Scientific, F530S). Az alkalmazott PCR programok a következök voltak: $98^{\circ} \mathrm{C}-30$ másodperc, $98^{\circ} \mathrm{C}$ - 10 másodperc; $55{ }^{\circ} \mathrm{C}$ - 30 másodperc, a $72{ }^{\circ} \mathrm{C}$-os elongációs fázis a PCR1 esetében 55 , a PCR2 reakciónál 10, míg a PCR3 esetében 70 másodperc volt. A $72{ }^{\circ} \mathrm{C}$-os utópolimerizációs lépés a PCR1 esetében 5 perc, PCR2 reakciónál 2 perc, míg a PCR3-nál 10 percig tartott, a reakciók során a ciklusszám 35 volt.

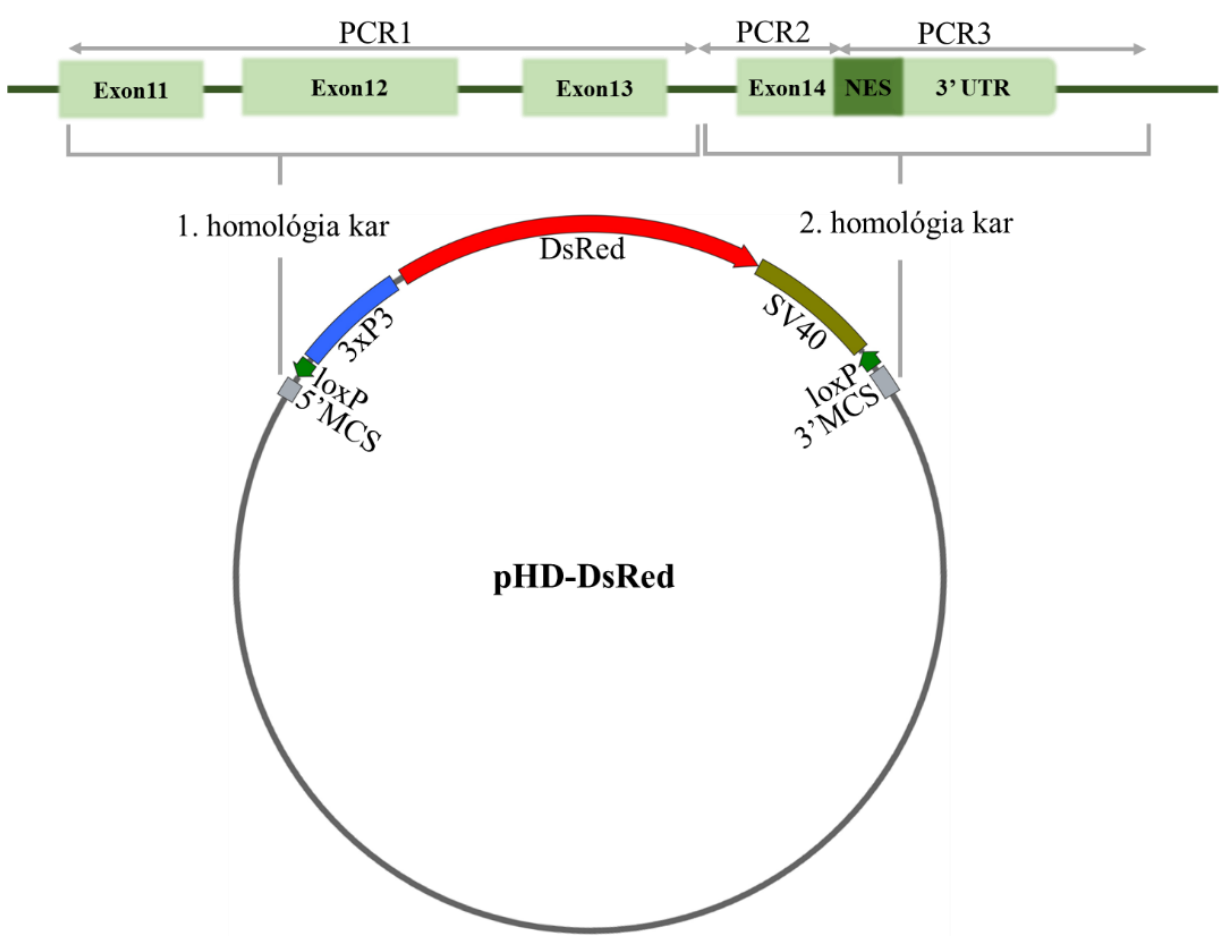

11. ábra. A NES beépítésekor használt donor konstrukt szerkezete.

Az első PCR reakció (PCR1) terméke adta az első homológiakart, melyet az 5' multiklónozó helyre, míg a második (PCR2) és harmadik (PCR3) PCR reakciók termékeiből álló második homológiakart a 3' multiklónozó helyre építettük be. loxP: a markergén eltávolításakor használt helyspecifikus rekombinációs szekvencia, $3 x P 3$ : szemspecifikus promóter, DsRed: piros fluorescens fehérjét kódoló markergén, SV40: poliadenilációs és terminációs szignál, MCS: multiklónozó hely. 
Az elkészített PCR termékek alkották a templát első és második homológiakarját, melyeket a pHD-DsRed plazmidba építettünk be. A vektort Erdélyi Miklós laboratóriuma (SZBK, Genetikai Intézet) bocsátotta a rendelkezésünkre. A két homológiakart egymástól egy eltávolítható, loxP helyek által határolt $D s R e d$ markergén választja el egymástól. Az első homológiakar esetében a vektort és az első PCR reakció (PCR1) termékét a NotI és EcoRI (Fermentas) enzimekkel emésztettük, majd az első homológiakart T4 DNS ligázzal (New England BioLabs, M0202S) beépítettük a plazmidba. A második homológiakar összeépítéséhez a második (PCR2) és harmadik PCR (PCR3) reakciók termékeit HindIII (Fermentas) enzimmel hasítottuk és egymáshoz ligáltuk. Ezt követően az első homológiakart tartalmazó fragmentet a SapI (New England BioLabs) enzimmel hasított pHD-DsRed plazmidba építettük (11. ábra). Az elkészült donor konstruktot 2T1 kompetens E. coli sejtekbe transzformáltuk. A DNS izolálást követően (Geneaid - High-Speed Plasmid Mini Kit) a homológiakarokat tartalmazó donor konstruktot szekvenáltatással ellenőriztük.

\subsubsection{A NES szekvencia génbe épülésének ellenörzése PCR-rel}

A beépülést ellenőrző PCR-hez (Phusion High-Fidelity DNA Polymerase, Thermo Fisher Scientific) és szekvenáltatáshoz használt oligonukleotidok a következőek voltak: gMoeFw7 forward (5'- GAGATTCGTAAGGGCAACACA-3') és gMoeRev reverz (5'GTCCTTCCTAACCGTCTTCTC-3') primerek. Templátként egyetlen hím légyből (moe $[\mathrm{NES}] / \mathrm{Y})$ izolált genomi DNS-t használtuk. A PCR reakció összetétele: 27,5 $\mu 1$ desztillált víz; $10 \mu 1$ High Fidelity puffer, $2 \mu$ l genomi DNS egy légyből; 4,0 $\mu 1$ dNTP (2,5 mM törzsoldatból); 3,0 $\mu 1$ forward primer ( $5 \mu \mathrm{M}$ törzsoldatból); 3,0 $\mu 1$ reverz primer ( $5 \mu \mathrm{M}$ törzsoldatból); 0,5 $\mu 1$ Phusion High-Fidelity DNS polimeráz (Thermo Fisher Scientific, F530S). A PCR során használt program: $98{ }^{\circ} \mathrm{C}$ - 30 másodperc, $98{ }^{\circ} \mathrm{C}$ - 10 másodperc, $53{ }^{\circ} \mathrm{C}$ - 25 másodperc, $72{ }^{\circ} \mathrm{C}-30$ másodperc, $72{ }^{\circ} \mathrm{C}-5$ perc. A reakció során a ciklusszám 35 volt.

\subsubsection{A moe[NES] génröl képződő mRNS izolálása és szekvenálása}

A moe[NES] legyekből izolált totál mRNS mintából $1 \mu \mathrm{g}$ izolált RNS-hez $1 \mu 1$ PATanchor primert adtunk, majd a mintát kiegészítettük $8 \mu$ l RNáz-mentes vízzel (Thermo Fisher Scientific, Nuclease-free Water (not DEPC-treated), AM9938). Ezt követte 5 perc inkubáció $80{ }^{\circ} \mathrm{C}$-on, majd a mintát lehütöttük $25^{\circ} \mathrm{C}$-ra. A törmelék lecentrifugálása (18000 x g) után a mintához adtunk $12 \mu$, előre összemért és jégen tartott reakcióelegyet $\left(4 \mu \mathrm{ld} \mathrm{d}_{2} \mathrm{O}\right.$, $4 \mu 1$ x reverz transzkriptáz puffer, $1 \mu 1100$ mM DTT, $1 \mu 110$ mM dNTPs, $1 \mu 1$ RNázOUT, 
0,5 $\mu 1(5 \mathrm{U})$ Klenow polimeráz (Fermentas, EP0051). A $25^{\circ} \mathrm{C}$-on történő, egy órás inkubációt követően a mintát 10 percig $80{ }^{\circ} \mathrm{C}$-on tartottuk, majd $55^{\circ} \mathrm{C}$-ra lehütve 1 percig állni hagytuk. Ezután a reakcióhoz $1 \mu 1$ reverz tranzkriptáz (Invitrogen, SuperScript IV, 18090010) hozzáadása után 1 óráig tartó inkubáció következett $55^{\circ} \mathrm{C}$-on. Végül a reverz transzkriptáz inaktivációjához a mintát $80{ }^{\circ} \mathrm{C}$-on tartottuk 10 percig és $\mathrm{PCR}$ alkalmazásával (Phusion High-Fidelity DNA Polymerase, Thermo Fisher Scientific, F530S) a moe[NES] cDNS-re specifikus gMoe_3'_reverz_primer (5'- TCGCTGGTGGGATAGTTAGC -3') és MoePCR3'_Fw (5'- CTGGACACCGACGAGCATA -3') primerpárral amplifikáltuk az mRNS-t. A keletkezett terméket a MoePCR3'_Fw primerrel történő szekvenálással ellenőriztük.

\subsubsection{Genomi DNS izolálása egy légyből}

A NES beépülésének ellenőrzésére a mutáns vonalakból egy-egy moe[NES]/Y hímet, valamint a donor konstrukt megépítéséhez használt 5 kbp-os moesin génszakasz amplifikálásához $w^{1118} / w^{1118}$ legyet kiválasztottunk, majd 1.5 ml-es centrifugacsőben 10 percig $-80{ }^{\circ} \mathrm{C}$-on tartottuk, hogy elpusztuljon. A legyekre 50-50 $\mu \mathrm{l} \mathrm{SB}$ oldatot (10 mM Tris$\mathrm{HCl}(\mathrm{pH} 8,2), 1 \mathrm{mM}$ EDTA, $25 \mathrm{mM} \mathrm{NaCl}, 200 \mu \mathrm{g} / \mathrm{ml}$ proteináz $\mathrm{K})$ mértünk, majd homogenizáltuk őket. Következő lépésként 30 perces, $37^{\circ} \mathrm{C}$-os inkubáció, majd 10 perces, $95{ }^{\circ} \mathrm{C}$-os hőinaktivációt végeztünk. Ezután a mintákat centrifugáltuk $\left(25^{\circ} \mathrm{C}, 18000 \mathrm{x} \mathrm{g}\right)$, majd a felülúszót a PCR reakciók során templátként használtuk.

\subsubsection{Teljes mRNS szekvenálás}

\subsubsection{Teljes mRNS izolálása}

Ezekhez a kísérletekhez az eszközöket használat előtt dietilpirokarbonáttal (DEPC) kezeltük és sterileztük. Az oldatokat szintén DEPC-kezelt, steril desztillált vízzel készítettük. A moe[NES] mutáns vonalból 10 hímet $\mathrm{CO}_{2}$-dal elaltatva $1 \mathrm{ml} 4{ }^{\circ} \mathrm{C}$-os TRIzol oldatban (Thermo Fisher Scientific) homogenizáltunk, majd szobahőmérsékleten 5 percig inkubáltunk. A homogenizátumot 5 percen keresztül 15610 x g-n $4{ }^{\circ} \mathrm{C}$-on centrifugáltuk. Ezt követően a felülúszóhoz $200 \mu 1$ kloroformot adtunk, majd 3 perces inkubáció következett. A mintát ezután 15 percen keresztül 15610 x g-n centrifugáltuk $4{ }^{\circ} \mathrm{C}$-on. Az RNS-eket tartalmazó felső vizes fázishoz $500 \mu$ izopropanolt adtunk, majd 10 perces inkubáció következett szobahőn. Az inkubáció után a mintákat újra centrifugáltuk (10 perc, 15610 x g, 
$4{ }^{\circ} \mathrm{C}$ ), a pelletet $1 \mathrm{ml} 75 \%$-os etanollal mostuk, majd ismételt centrifugálás következett $4{ }^{\circ} \mathrm{C}$ on (5 perc, 6100 x g). A csapadékot szárítás után $20 \mu$ l RNáz-mentes vízben (Ambion, Nuclease-free water (not DEPC-treated), AM9938) 55-60 ${ }^{\circ} \mathrm{C}$-on feloldottuk.

\subsubsection{Teljes mRNS minták elökészitése a szekvenáláshoz}

A teljes mRNS szekvenáláshoz a PBS-ben kiboncolt 3 napos 10-10 darab $m o e^{\mathrm{G} 0415} /$ moe $[\mathrm{NES}]$, moe $e^{\mathrm{G} 0415} / w^{1118}$, valamint $w^{1118} /$ moe [NES] nőstények petefészkeiből teljes mRNS-t izoláltunk a fent részletezett módon (2.2.3.1. Teljes mRNS izolálása), majd az mRNS szekvenálást Piergiorgio Percipalle laboratóriuma (New York University Abu Dhabi) végezte el a számunkra Tomas Venit és munkatársai által közölt cikk alapján (Venit és mtsai, 2020).

\subsubsection{Teljes $m R N S$ szekvenálás adatainak a feldolgozása}

A teljes mRNS szekvenálás adatainak kiértékelését a Nucleic Acid SeQuence Analysis Resource (NASQAR) online programmal (http://nasqar.abudhabi.nyu.edu/GeneCountMerger) végeztük el. A program által használt CG számok Flybase azonosítóvá konvertálására a Flybase ID Converter programot (http://biotools.fr/drosophila/fbgnconverter) használtuk. A doboz ábrákhoz (50., 51.,52., és 53. ábra) felhasznált adatokat három párhuzamos biológiai minta szolgáltatta minden genotípus esetében. A $\log 2 \mathrm{cpm}$ a $\log 2$ counts per million rövidítése. A doboz ábrák elkészítéséhez a START: Shiny Transcriptome Analysis Resource Tool online programot használtuk.

\subsubsection{Kvantitatív PCR (qPCR)}

A vizsgálathoz 5 nőstény légy petefészkét boncoltuk ki hideg PBS-ben. A petefészkeket kupakos centrifuga csőbe gyüjtöttük, majd a PBS eltávolítása után $500 \mu 1$ Drosophila Schneider's tápoldatban (Lonza, Schneider's Drosophila Medium, Modified, 04351Q) $37{ }^{\circ} \mathrm{C}$-on hősokkoltuk 30 percig. Ezt követően a tápoldatot eltávolítottuk, majd a mintákat folyékony nitrogénben fagyasztottuk. A qPCR vizsgálatokat, valamint az RNS izolálást Dr. Sinka Rita laboratóriumában (SZTE, Genetika Tanszék) Dr. Vedelek Viktor végezte el a számunkra. Az ováriumokat homogenizátorral porították, majd $350 \mu$ l bétamerkaptoetanollal kiegészített RLT Plus Lysis pufferben tovább homogenizálták (RNeasy Plus Micro Kit, Qiagen, Cat, No. 74034). A lizátumot 3 percig 13000 x g-n centrifugálták, majd a felülúszót a Rneasy Plus Kit (Qiagen, Cat. No. 74134) gDNA Eliminator oszlopára 
töltötték, és egy percig centrifugálták (18000 x g). Ezt követően az átfolyót a Quick-RNA Miniprep Kit Spin-Away Filter (Zymo Research, Cat. No. R1057) oszlopra töltötték fel. Ettől a lépéstől a Zymo Research Quick-RNA Miniprep Kit protokollja szerint folytatták az RNS kinyerését, azzal a módosítással, hogy DNáz I kezelés időtartamát 30 percre emelték fel. A cDNS-t $2 \mu \mathrm{g}$ tisztított RNS-ből, a RevertAid First Strand cDNA Synthesis Kit (Thermo Fisher Scientific, K1622) felhasználásával, random hexamer primerekkel, a gyártó által ajánlott protokoll szerint készítették el. A qPCR reakciókat a Thermo Scientific Maxima SYBR Green/ROX qPCR Master Mix (2X) felhasználásával triplikátumokban végezték el, az alábbi program alapján: $95{ }^{\circ} \mathrm{C}-10$ perc, 45 ciklus: $95{ }^{\circ} \mathrm{C}-10$ másodperc, $54{ }^{\circ} \mathrm{C}-15$ másodperc, $72{ }^{\circ} \mathrm{C}-20$ másodperc. A reakciókat Rotor-Gene Q (Qiagen) gép segítségével analizálták, valamint Rotor-Gene Q Series Software és Q-Rex programok használatával értékelték ki. A relatív gén expresszió meghatározásához rp49 háztartási gént használták fel referenciának. A reakciókhoz alkalmazott primerek és szekvenciáik a függelékben találhatók.

\subsection{Sejtkultúra módszerek}

\subsubsection{Az S2R+ sejtek fenntartása, transzfekciója}

A kísérletekhez használt Drosophila sejteket $25{ }^{\circ} \mathrm{C}$-on Drosophila Schneider's tápoldatban (Lonza, Schneider's Drosophila Medium, Modified, 04-351Q) tenyésztettük, mely 10\% FBS szérumot (Biowest, Fetal Bovine Serum, S1820-500) és 1\% antibiotikum oldatot (Penicillin-Streptomycin, Lonza, DE17-603E) tartalmazott. A transzfekcióhoz az Effectene Transfection Reagent Kit-et (QIAGEN, 301425) használtuk. A kísérleteket 24 lyukú sejttenyésztő lemezen (Thermo Fisher Scientific, Nunclon 24-Well x 1 ml MultiDish Cell Culture Dish, 142475) végeztük $1,5 \times 10^{5}$ sejt/lyuk kiindulási sejtszámmal. A sejteket 5 napon keresztül neveltük a sejttenyésztő lemez lyukaiba helyezett, $12 \mathrm{~mm}$ átmérőjü üveg fedőlemezeken (ROTH, P231.2).

\subsection{2. $\mathrm{S} 2 \mathrm{R}+$ sejtek immunfestése}

A tápoldat eltávolítása után a sejteket PBS-sel mostuk, majd 4\%-os paraformaldehidet tartalmazó PBS-ben szobahőn 20 percig fixáltuk, végül 3x2 percig újra mostuk PBS-sel. Ezután 5 percig inkubáltuk a mintákat PBT-ben, 1 órán keresztül blokkoltuk PBT-N oldatban, végül az anti-GFP (Rabbit, 1:500, Thermo Fisher Scientific, A6455) elsődleges 
ellenanyaggal $4{ }^{\circ} \mathrm{C}$-on egy éjszakán át forgattuk. Másnap a sejteket $3 \times 2$ percig mostuk PBSben, és a másodlagos ellenanyaggal (goat anti-rabbit Alexa Fluor-488, 1:600, Thermo Fisher Scientific, A11008) 1 órán keresztül inkubáltuk szobahőn. A 3x2 perces PBS-sel történő mosás után a sejteket 1 órán át kezeltük a filamentáris aktin jelöléséhez használt Phalloidin Alexa Fluor-546 (1:40, Thermo Fisher Scientific, A22283) festékkel és DAPI-val. A másodlagos festéseket követően a mintákat $3 \times 2$ percig mostuk PBS oldatban, majd tárgylemezre helyeztük és $8 \mu \mathrm{l}$ beágyazó médiummal (Fluoromount G, Thermo Fisher Scientific, 00-4958-02) lefedtük. Az eredmények értékelését Olympus (Olympus Fluoview FV1000 Confocal Microscope, 40x olajimmerziós objektív, 1.3 NA), és Leica (Leica TCS SP5, 63x olajimmerziós objektív, 1.4 NA) konfokális mikroszkópokon végeztük.

\subsubsection{A transzfekcióhoz használt expressziós konstruktok elkészítése}

A kísérletekhez használt egyes Moesin formákat a Quick Change II Site Directed Mutagenesis Kit és a Q5 Site-Directed Mutagenesis Kit (New England BioLabs, E0554S) segítségével állítottuk elő. A SLIC módszer során használt T4 DNS polimerázt a New England BioLabs cégtől szereztük be. Templátként a Moesin-pDONR221 vektort használtuk, mely tartalmazza a teljes moesin cDNS szekvenciát. Az elkészített módosított moesin szekvenciát a pAWG vektorba építettük be a Gateway LR Clonase II Enzyme Mix (Thermo Fisher Scientific, 11791-020) alkalmazásával a gyártó utasításainak megfelelően. Az egyes Moesin izoformák előállításakor használt primerek és szekvenciáik a függelékben találhatók. A MAL-GFP termeléséhez használt konstrukt Maria Vartiainen laboratóriumából származik, mely az egér MAL fehérje cDNS-ét tartalmazza (Dopie és mtsai, 2012). 


\section{EREDMÉNYEK}

\subsection{A sejtmagi import vizsgálata}

A Moesin sejtmagi importjának vizsgálata során a korábban a laboratóriumunkban azonosított NLS1 szekvencia részletes jellemzését végeztem, valamint annak szabályozását tanulmányoztam S2R+ sejttenyészeten. nyugalmi körülmények között ugyan a Moesin fehérje csak kis mennyiségben van jelen a sejtmagban, de az mRNP komplexek szállításában résztvevő Rael export faktor (RNA export factor 1) mRNS-ének csendesítése esetén a Moesin magi felhalmozódása figyelhető meg. Ennek oka nagy valószínűséggel az, hogy a sejt a csökkent Rae1 mennyisége miatt gátolt mRNS exportot a többi mRNP szállításban résztvevő faktor importjának növelésével próbálja ellensúlyozni (Kristó és mtsai, 2017). Ezt a jelenséget felhasználva végeztem a Moesin sejtmagi importjának vizsgálatát.

\subsubsection{A Moesin NLS szekvenciájának azonosítása}

A csoportunk egy NLS szekvencia azonosító program (NucPred) alkalmazásával már korábban meghatározta a lehetséges, sejtmagi lokalizációért felelős régiókat a Moesin fehérjében (nem publikált adat). Kristó Ildikó, a munkája során, a 294-297 aminosav pozícióban található RRRK, illetve a 447-450 pozícióban található RRKQ régiókat kapta eredményül, amelyeket NLS1 és NLS2 szekvenciáknak nevezett el (12. ábra).

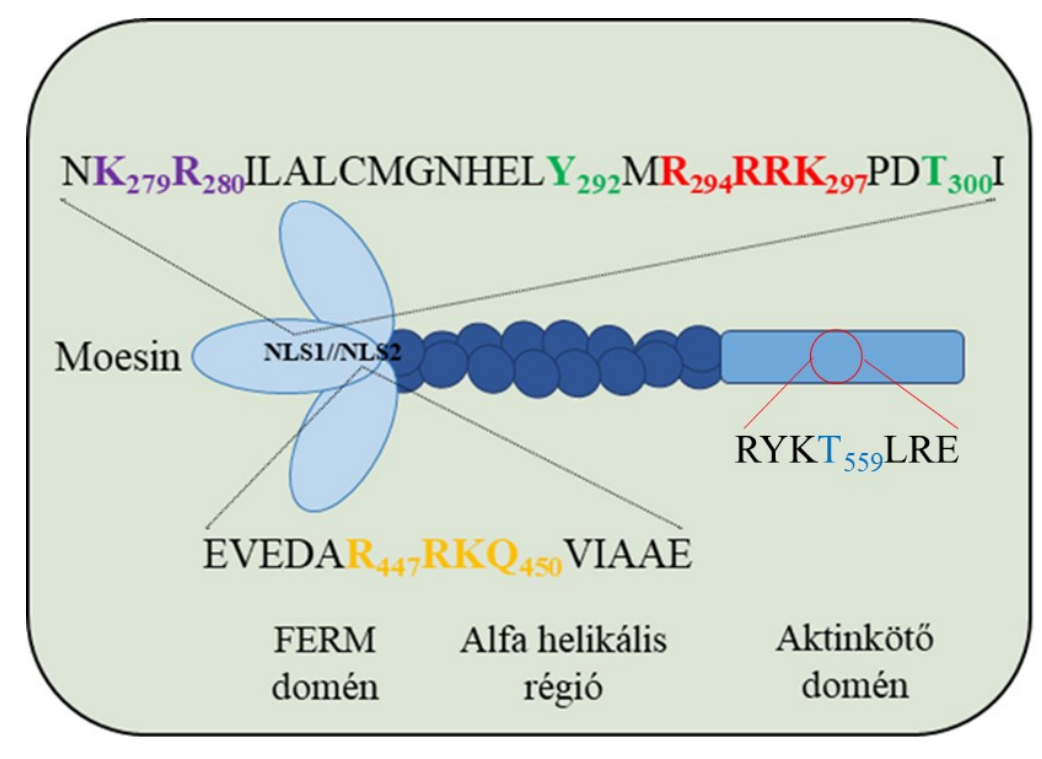

12. ábra. A Drosophila Moesin NLS szekvenciája.

Az NLS1 motívum egyik tagja pirossal, míg a másik tagja lilával, valamint az NLS2 sárgával van jelölve. A feltehetően szabályzó funkcióval rendelkező aminosavakat zöld színnel, míg az aktiváció során foszforilálódó treonint kékkel jelöltük. 
Az RRRK és RRKQ régióknak a sejtmagi importban betöltött szerepét oly módon vizsgálta, hogy az érintett aminosavakat eltávolította, majd az így létrehozott $\Delta R R R K$ (Moe$\triangle$ NLS1) és $\triangle$ RRKQ (Moe- $\Delta$ NLS2) fehérjeváltozatok sejtmagi importját indukálta a rae1 gén csendesítésével (13. ábra).

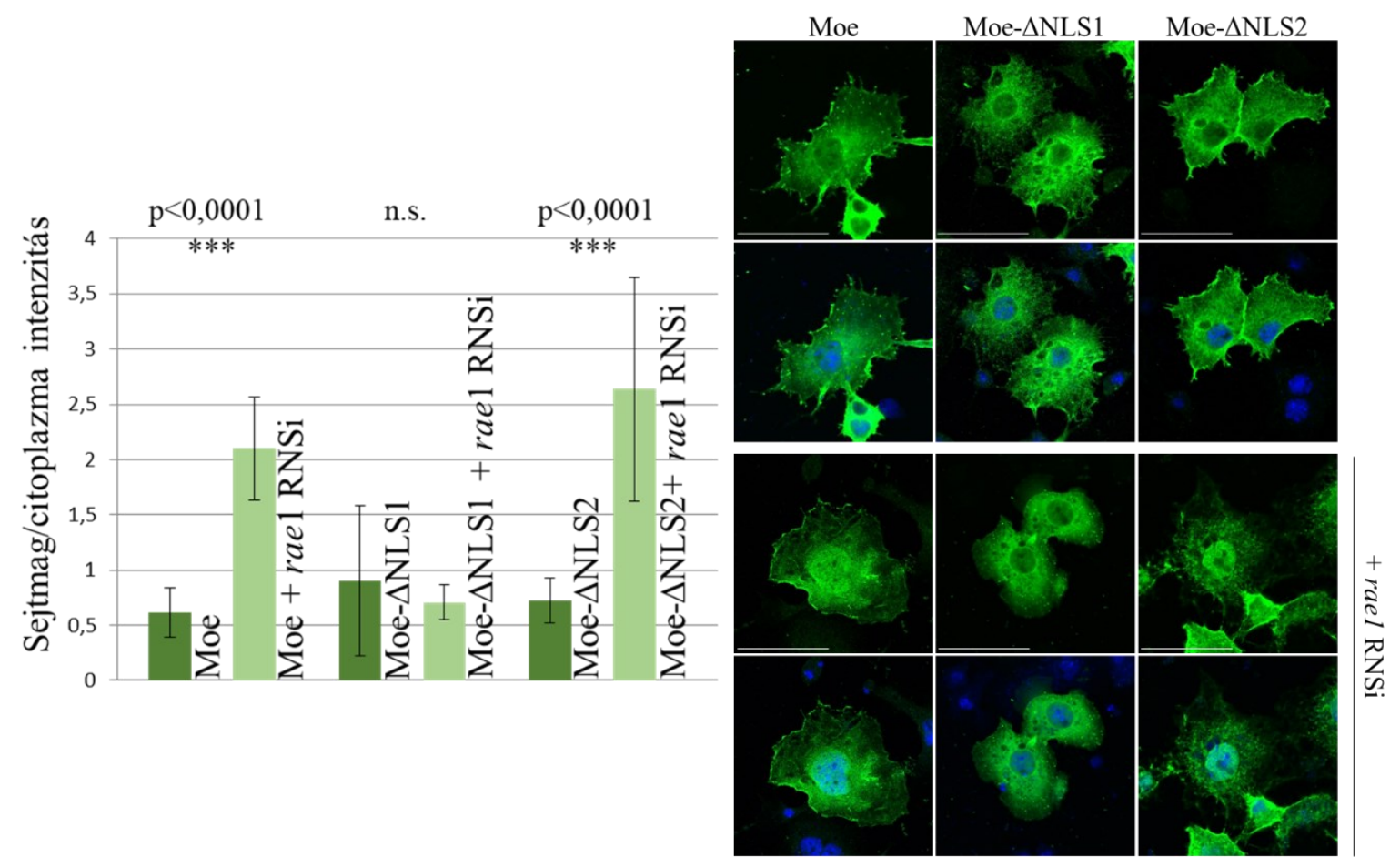

13. ábra A Moesin NLS szekvenciájának azonosítása.

A feltételezett NLS szekvenciák eltávolítását követően minden Moesin-GFP fehérjeváltozat (zöld szín) kis mennyiségben megtalálható a sejtmagban. A rael gén (rael RNSi) csendesítése esetén kizárólag a Moe- $\triangle$ NLS1 forma nem volt képes sejtmagi halmozódásra. DAPI festés: kék. Kristó Ildikó munkája.

$\mathrm{Az}$ eredmények alapján elmondható, hogy normál körülmények között mindkét mutáns fehérje a vad típusú, teljes hosszúságú Moesinnel megegyező módon helyezkedik el a sejtekben. A Moesin sejtmagi importjának indukálásakor, azonban a rael gén csendesítése esetén az NLS1 forma a többi Moesin formával ellentétben nem halmozódott fel. Ezek alapján elmondható, hogy az NLS1 szekvencia valóban egy működő sejtmagi lokalizációs szignálnak tekinthetö.

Ahogy például a nukleoplazmin esetében is megállapították korábban, egyes fehérjék olyan NLS-eket tartalmaznak, amelyek két külön motívumból épülnek fel. Az egyes motívumokat általában 10-12 aminosavból álló összekötő régió választja el egymástól (KR 10-12RRRK), így ezeket a lokalizációs szekvenciákat kéttagú NLS-eknek nevezzük (Harreman és mtsai, 2004). A Moesin esetében az NLS1 szekvenciától N-terminális 
irányban, a 279-280 pozícióban található egy $\mathrm{KR}$ motívum ( $\left.\mathrm{KR}_{13} \mathrm{RRRK}\right)$, melynek aminosav összetétele és pozíciója teljesíti a kéttagú NLS-ekre megállapított feltételeket. Annak eldöntésére, hogy a Moesin NLS szekvenciája valóban két tagból épül-e fel, a KR motívumot eltávolítottuk (Moe- $\Delta \mathrm{KR}$ ) és megvizsgáltuk az így létrehozott fehérje (Moe$\Delta \mathrm{KR}$ ) sejtmagi halmozódását rael RNS interferencia mellett (14. ábra).
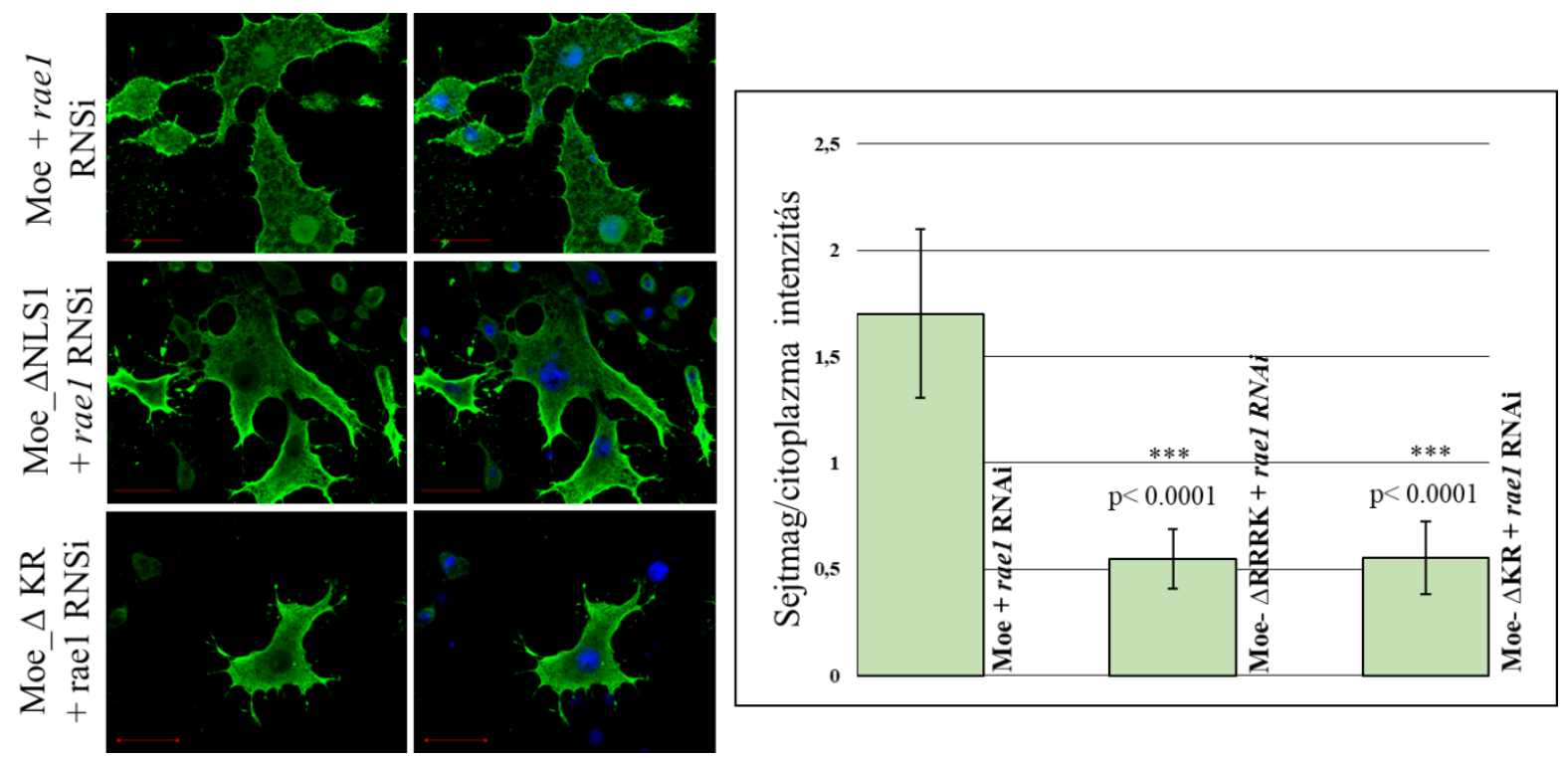

14. ábra Az NLS1 szekvencia második tagjának azonosítása.

A 279-280 pozícióban található KR aminosavak törlése után a Moesin (zöld szín) nem képes rael RNSi hatására halmozódni a sejtmagban. A $\Delta$ RRRK formához hasonló sejtmag/citoplazma intenzitási érték egyúttal arra is utalhat, hogy az egyes tagok egyforma mértékben vesznek részt az NLS aktivitásában. DAPI festés: kék.

Az eredmények azt mutatták, hogy a KR 279-280 motívum eltávolításakor a Moesin, hasonlóan a Moe- $\Delta$ NLS1 formához, nem képes a sejtmagba bejutni és halmozódni. Ez azt jelenti, hogy a KR és az RRRK motívumok együttesen alkotják az NLS1 szekvenciát, tehát az általunk azonosított NLS kéttagú. Pawlowski és munkatársai korábban megállapították, hogy a MAL transzkripciós kofaktor aktinfüggő sejtmagi importja esetében a kéttagú NLS hierarchikus felépítésű, az egyes motívumok eltávolítása eltérő mértékben csökkenti a MAL magi importját (Pawlowski és mtsai, 2010). Azonban a Moesin esetében az RRRK, illetve a KR eltávolításakor közel azonos sejtmagi fluoreszcencia intenzitási arányokat mértünk, amely arra enged következtetni, hogy a Moesin NLS1 szekvenciájának müködése szempontjából a két tag egyenrangú. 


\subsubsection{A sejtmagi import szabályozása}

Az irodalomból ismert, hogy az NLS szekvenciák környezetében található, foszforilálódni képes aminosavak szabályozó funkcióval rendelkezhetnek, foszforiláltsági állapotuktól függően elősegítik vagy gátolják az adott fehérje magi importját (Nardozzi és mtsai, 2010). A Moesin esetében az NLS1 szekvencia közelében található, vélhetően szabályozó szerepű tirozin (Y292) és treonin (T300) aminosavak (12. ábra) vizsgálatát állandó foszforilációs állapotot utánzó aszparaginsavra (Y292D), illetve nem foszforilálható alaninra (Y292A) történő cserélésükkel, és az így elkészített fehérjeváltozatok indukált sejtmagi importjának nyomon követesével végeztük. A mikroszkópos felvételek elemzése alapján elmondható, hogy sem a tirozin, sem a treonin foszforiláltsági állapota nem befolyásolja a sejtmagi importot, indukció hatására mindkét esetben szignifikánsan megemelkedik a sejtmagi Moesin mennyisége (15. ábra).

Ugyanakkor a Moe-Y292A és Moe-Y292D fehérje formák esetében kisebb sejtmagi halmozódást detektáltunk, mint a vad típusú Moesin esetében. Ezek alapján nem zárható ki az, hogy az aminosavcsere miatt módosul a Moe-Y292A és Moe-Y292D fehérje formák térszerkezete, mely kihat ezen Moesin izoformák sejtmagi importjára. Ezért a jövőben tervezzük a tirozint a szerkezetileg nagyon hasonló, de foszforilálódni képtelen fenilalaninra is lecserélni. Elképzeléseink szerint ez a kísérlet választ adhat arra, hogy a Moe-Y292A és Moe-Y292D forma gyengébb halmozódása az esetlegesen fellépő tészerkezeti változás következményeként alakult-e ki. Ugyanakkor a Moe-Y292A és Moe-Y292D formák egymáshoz hasonló nukleáris fluoreszcencia intenzitási értékkel rendelkeztek (15. ábra), valamint képesek a sejtmagi halmozódásra, melyek alapján feltételezhető, hogy a tirozin nem rendelkezik szabályozó funkcióval.

Az NLS1 közelében található másik foszforilálható aminosav, a treonin esetében egyértelmủen megállapítható, hogy nem játszik szerepet a Moesin importjában. A MoeT300D és a Moe-T300A fehérje forma is a vadtípussal közel azonos fluoreszcencia értékeket mutatott mind nem indukált, mind indukált sejtmagi import esetében. Ezek a kísérletek egyúttal megerősítik azt is, hogy a $\mathrm{KR}_{279-280}$ motívum esetében korábban megfigyelt importot szabályozó hatás valóban specifikus, és nem az NLS szekvencia közelében levő aminosav-környezet megváltozása miatt alakul ki aspecifikusan. 

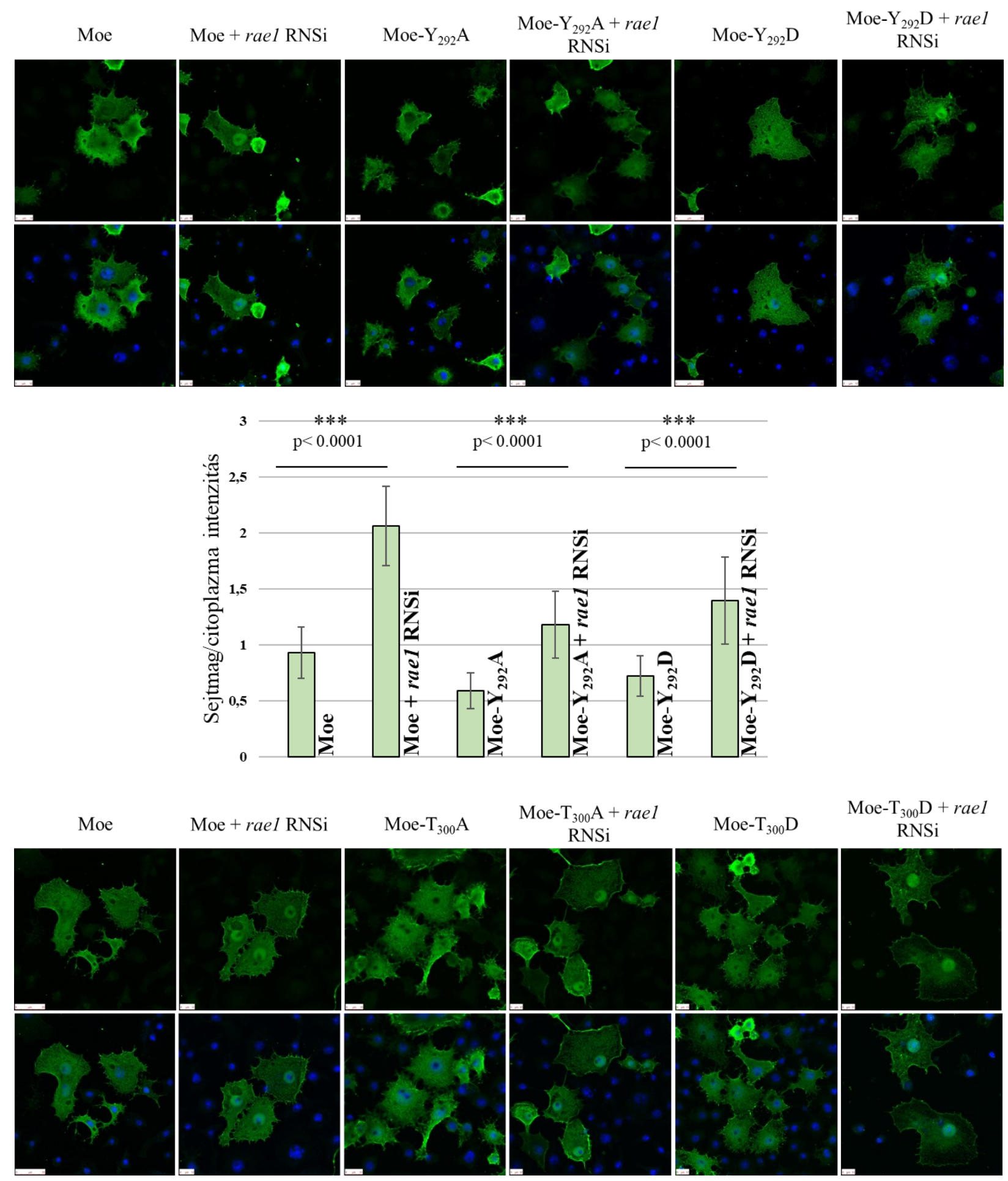


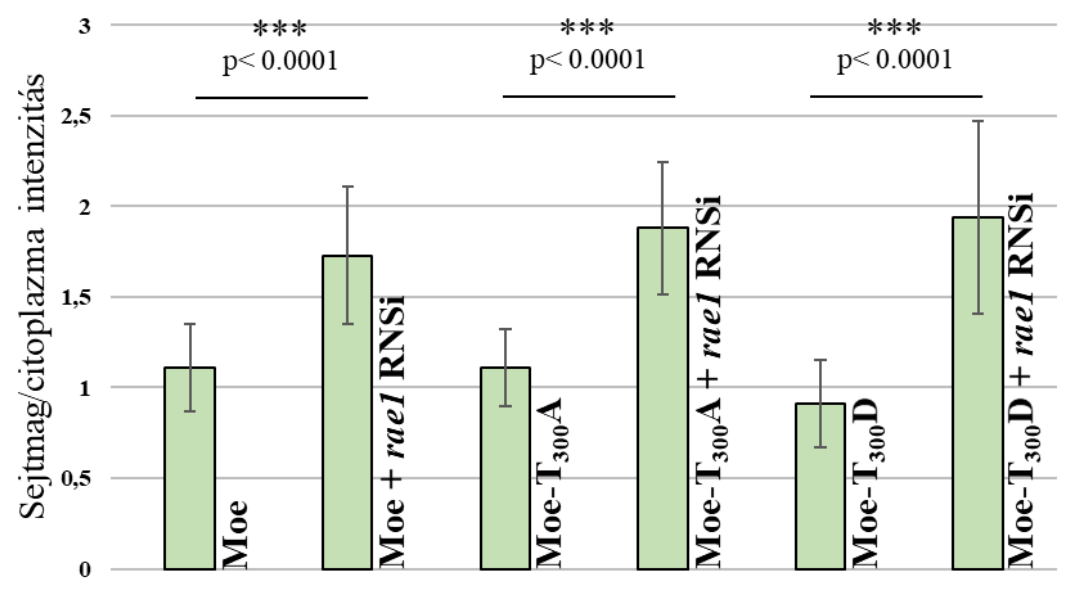

15. ábra Az RRRK motívum közelében elhelyezkedő, foszforilálódni képes aminosavak sejtmagi importot szabályozó funkcióinak tesztelése.

A 292. és 300. pozícióban található tirozin és treonin aminosavak nem rendelkeznek szabályzó funkcióval. Az állandó foszforiláltsági állapotot utánzó (Moe- $\mathrm{Y}_{292} \mathrm{D}$ és Moe$\mathrm{T}_{300} \mathrm{D}$ ), valamint a foszforilálódni képtelen (Moe- $\mathrm{Y}_{292} \mathrm{~A}$ és Moe- $\mathrm{T}_{300} \mathrm{~A}$ ) formák a vad típussal megegyező módon képesek halmozódni rael RNSi hatására. Az egyes Moesin

formákat zöld színnel, míg a DAPI festést kékkel jelöltük.

\subsubsection{A Moesin aktivációs állapota és sejtmagi transzportja közötti kapcsolat vizsgálata}

A Moesin fehérje alapállapotban megfigyelhető zárt konformációja egy többlépéses aktivációs folyamat eredményeként nyitottá válik (6. ábra a bevezetésben). Az aktiváció utolsó lépéseként az 559. pozícióban található treonin (12. ábra) foszforilálódik, aminek hatására a fehérje nyitott konformációja stabilizálódik. A továbbiakban azt vizsgáltuk, hogy a Moesin sejtmagi importjára milyen hatással van a fehérje aktivációs állapota. Ehhez elkészítettük azokat a fehérjeváltozatokat termelő konstrukciókat, amelyekben a Moesin aktivációjáért felelős treonint lecseréltük állandó foszforilációs állapotot utánzó aszparaginsavra (MoeT $559 \mathrm{D}-\mathrm{GFP}$ - „konstitutívan aktív” forma), valamint nem foszforilálható alaninra (MoeT ${ }_{559} \mathrm{~A}-\mathrm{GFP}$ - „inaktív” forma), majd a fehérjék sejtmagi importját vizsgáltuk rael RNS interferencia mellett. Az eredmények azt mutatták, hogy a vad típusú és az inaktív MoeT $_{559} \mathrm{~A}$ forma közel hasonló arányban volt jelen a sejtmagban, míg a MoeT ${ }_{559} \mathrm{D}$ mutatta a legkisebb sejtmagi halmozódást (16. ábra), ami arra utal, hogy a Moesin föként inaktív állapotban képes a sejtmagi importra. 

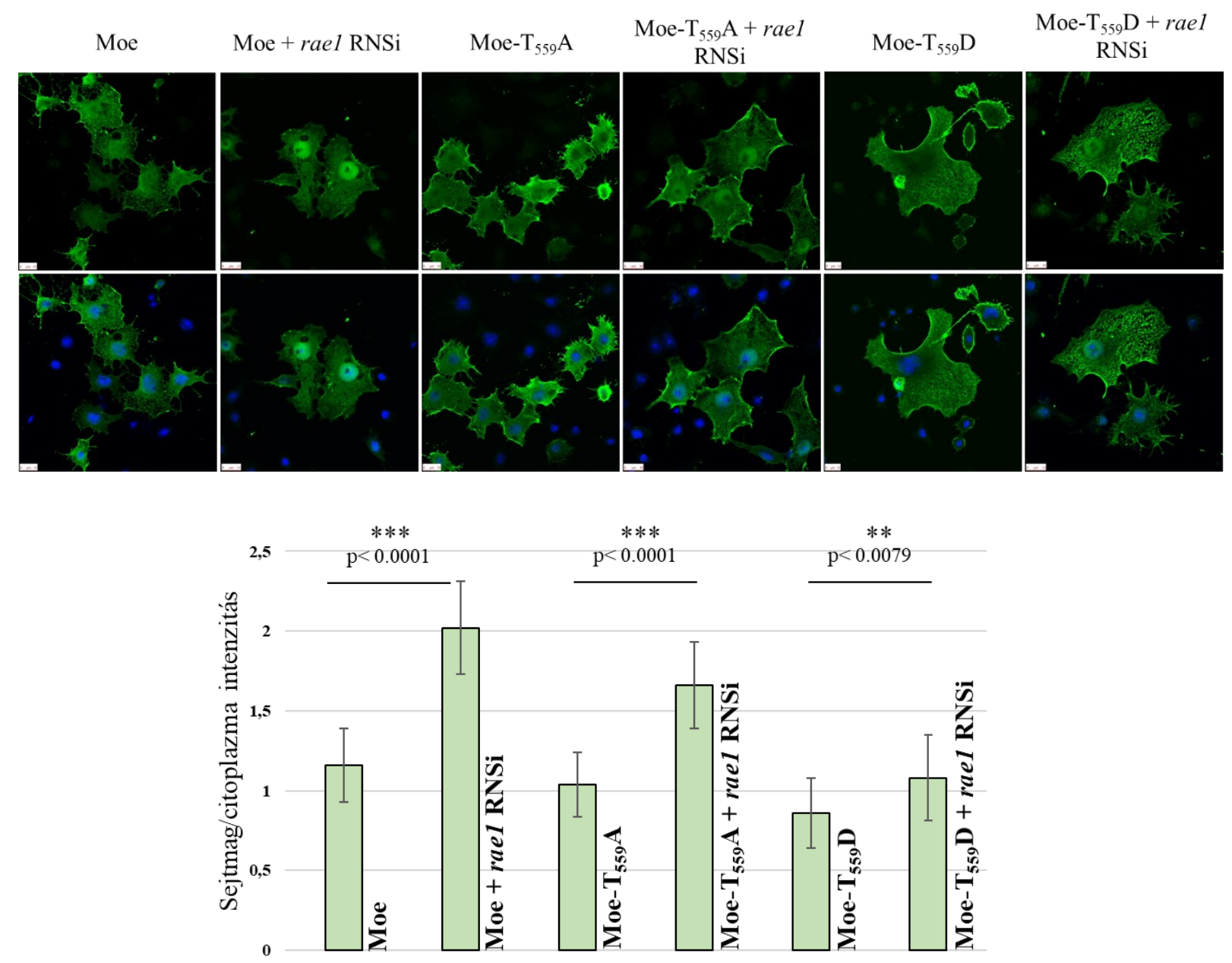

16. ábra A Moesin aktivációja és importja közötti kapcsolat vizsgálata.

A Moesin aktivációs állapotának módosításával megállapítható, hogy az állandóan aktív $\mathrm{MoeT}_{559} \mathrm{D}$ forma gyengébb magi halmozódást mutat, mint az inaktív formának tekintett

MoeT $_{559} \mathrm{~A}$. A fenti eredmények alapján elmondható, hogy a Moesin fóként inaktív formában alkalmas a sejtmagi transzportra. Moesin fehérje formák: zöld szín. DAPI festés: kék szín.

A konstitutívan aktív MoeT ${ }_{559} \mathrm{D}$ forma gyenge magi halmozódásának magyarázata valószínűleg nem elsősorban a gyenge importképesség, hanem az, hogy az aktivált Moesin forma és az aktin citoszkeleton között kialakuló erös kapcsolat gátolja a magi transzportot. Ezt a feltételezésünket erősíti François Payre laboratóriumában (CBI Toulouse) végzett munka, amelynek során kimutatták, hogy a $\mathrm{MoeT}_{559} \mathrm{D}$ izoforma sokkal nagyobb mennyiségben kötődik a sejtmembrán alatt húzódó F-aktin hálózathoz, mint a MoeT ${ }_{559} \mathrm{~A}$ változat (Roch és mtsai, 2010). Mindezek mellett további kísérletek lennének szükségesek annak megerősítésére, hogy az F-aktin valóban közvetve, az aktív Moesin forma citoplazmában történő megkötésével gátolja a sejtmagi importot. 
A Moesin fehérje aktivációja PIP 2 szekvenciális kötésével valósul meg. Ennek során a $\mathrm{PIP}_{2}$ molekula a Moesin fehérjén a tranziens kötőhelyről (PATCH K254,K255,K263,K264) a stabil kötőhelyre (POCKET - K61,K64,K279) kerül át. A korábbi kísérletekben az NLS első tagjaként meghatározott, 279-280 pozícióban levő KR motívum lizinje a POCKET kötőhely része, ami felveti annak a lehetőségét, hogy valójában a $\mathrm{PIP}_{2}$ kötése szükséges a Moesin sejtmagi importjához. Ezért a továbbiakban a FERM domén harmadik alegységében, a 254-255 és 263-264 pozíciókban található lizineket (PATCH) alaninra cseréltük. Így a fehérje aktivációjának feltételét jelentő, a $\mathrm{PIP}_{2}$ kötés első lépéséért felelős PATCH kötőhelyet teljesen elrontva egy olyan Moesin formát (MoeKA) hoztunk létre, melyben a POCKET kötőhely érintetlen, ám mégsem képes $\mathrm{PIP}_{2}$ megkötésre. Ezzel a mutáns formával elvégzett kísérlet azt mutatta, hogy a MoeKA a vad típusú Moesinnel megegyező módon képes halmozódni rael RNS interferencia hatására, melynek alapján kijelenthetjük, hogy a Moesin sejtmagi transzportjához a $\mathrm{PIP}_{2}$ kötése nem szükséges (17. ábra). Ez az eredmény egyúttal azt is megerősíti, hogy a KR aminosavak hiánya nem a PIP2 kötés elmaradása miatt gátolja a sejtmagi importot, hanem azért, mert sejtmagi importért felelős motívumot képeznek, tehát az NLS valóban kéttagú. 

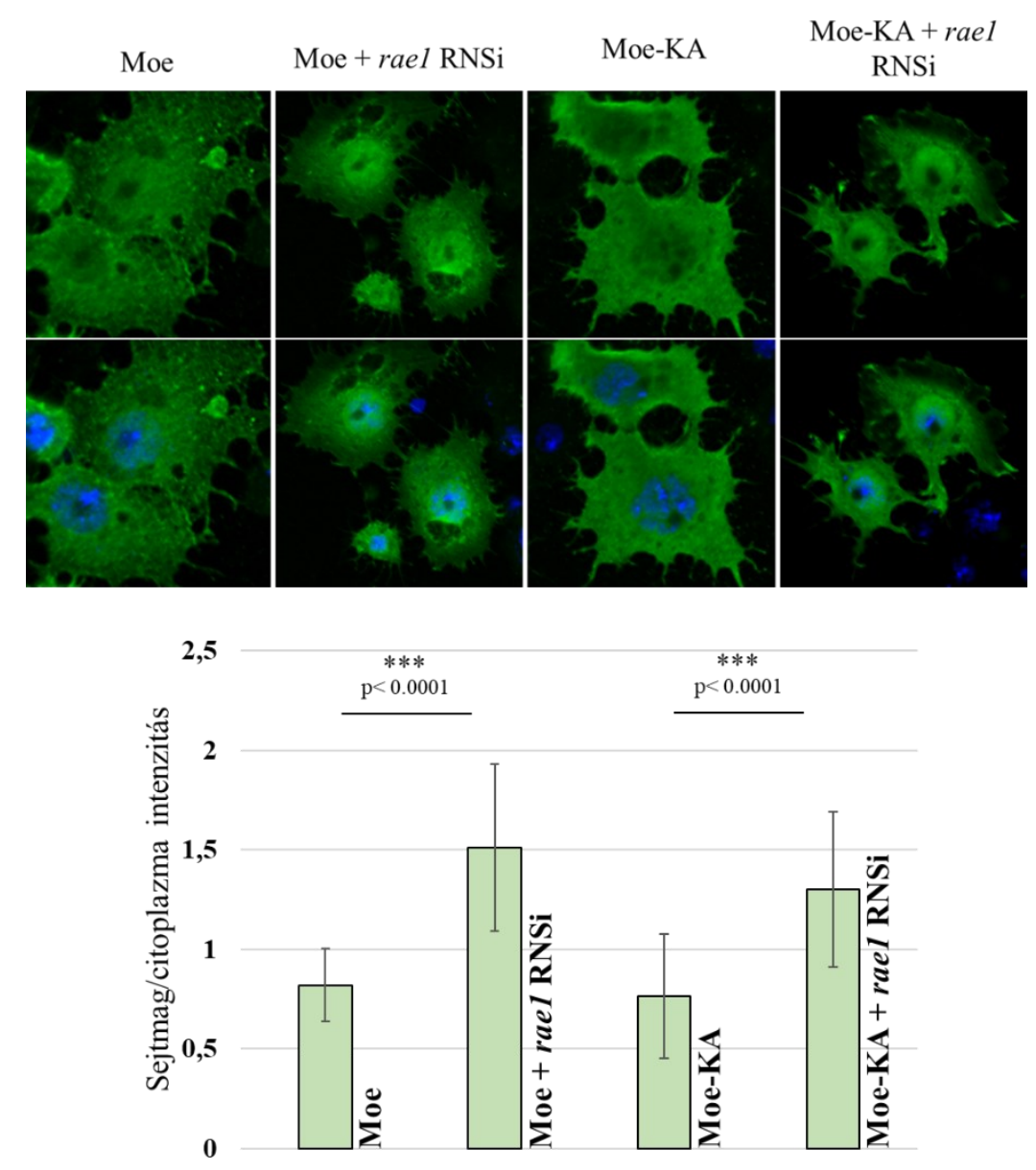

\section{7. ábra A konstitutívan inaktív, PIP2 kötésre képtelen MoeKA forma sejtmagi importjának vizsgálata.}

A MoeKA Moesin forma a vad típusú Moesinhez hasonló módon képes a sejtmagi halmozódásra rael RNSi hatására. Ezek alapján megállapítható, hogy a Moesin sejtmagi importjához a PIP 2 kötés nem szükséges, következésképp a transzport a fehérje inaktív, zárt konformációjában is megtörténik.

A szakirodalomban általánosan elfogadott módon a $\mathrm{MoeT}_{559} \mathrm{~A}$ fehérjeváltozatra inaktív formaként hivatkoznak, azonban tapasztalatunk szerint ez az aminosavcsere nem biztosítja a teljes inaktivitást. Ezt bizonyítja az UASp $>M_{0} T_{559}$ A törzzsel végzett menekítési kísérletünk is, amely azt mutatta, hogy a MoeT ${ }_{559} \mathrm{~A}$ transzgén hatékonyan képes a moe null mutációt menekíteni (31. ábra). Mivel a PIP 2 megkötése a PATCH kötőhelyen alapfeltétele a Moesin aktivációjának, így következésképpen a MoeKA fehérje forma nagy valószínüséggel valóban teljesen inaktív. A MoeKA sértetlen sejtmagi importja tehát egyúttal megerősíti a MoeT 559 A ,inaktív” formával kapott eredményt is, nevezetesen azt, hogy a fehérje importjához nincsen szükség aktiválódásra, zárt, inaktív konformációban is bejut a sejtmagba. 


\subsubsection{A sejtmagi import aktinfüggése}

Dolgozatomban már korábban említésre került, hogy az aktin közvetlenül is részt vesz az aktinkötő MAL transzkripciós kofaktor sejtmagi importjának szabályozásában. A Moesin NLS1 szekvenciája és környezete evolúciósan konzervált, minden ERM fehérjében megtalálható, továbbá a humán Ezrin esetében ez a régió G-aktin kötőhelyként is funkcionálhat (Roy és mtsai, 1997). Ezért megvizsgáltuk, hogy a monomer aktin befolyásolja-e a Moesin magi transzportját. A Moesin importjának monomer aktintól történő függését az aktin filamentumokat stabilizáló szerrel (Jasplakinolid - csökkenti a monomer aktin szintet) történt kezeléssel, valamint nem polimerizálódó, $\mathrm{R}_{63} \mathrm{D}$ mutációt hordozó aktin (Posern és mtsai, 2002) fehérje túltermelésével (növeli a monomer aktin szintet) vizsgáltuk. A két kísérlet azt mutatta, hogy a MAL kontroll fehérjével ellentétben a G-aktin szintjének csökkentése nem indukálta a Moesin sejtmagba áramlását, míg növelése pedig egyáltalán nem gátolta az indukált Moesin importot (18. ábra). Ezen eredmények alapján tehát elmondható, hogy a Moesin sejtmagba jutása független a monomer aktin mennyiségétől, vagyis a G-aktin nem szabályozza a Moesin sejtmagi importját.

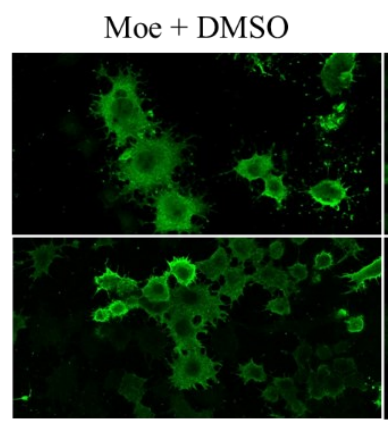

Moe + Jasplakinolide

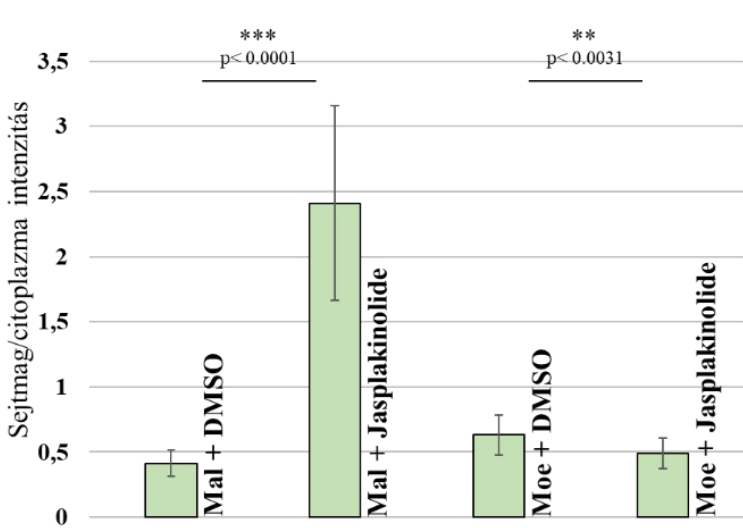

MAL + DMSO

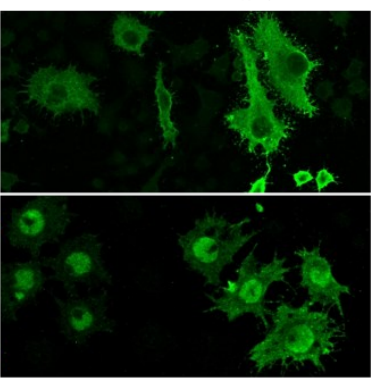

MAL + Jasplakinolide
18. ábra A Moesin sejtmagi importjának aktinfüggése.

A Moesin importját nem befolyásolja sem a lecsökkent (Jasplakinolid kezelés), sem a megemelkedett ( $\mathrm{R}_{63} \mathrm{D}$ aktin-RFP) G-aktin szint. Piros színnel az $\mathrm{R}_{63} \mathrm{D}$ aktin-RFP, míg zölddel a Moesin fehérjét jelöltük. MAL: pozitív kontrollként használt fehérje, DMSO: a Jasplakinolid oldószere. 


\subsection{A sejtmagi funkció vizsgálata}

Az előzőekben ismertetett kísérletek azt bizonyították, hogy a Moesin mennyiségét a sejtmagban NLS-függő, szabályozott import határozza meg, illetve korábbi kutatási eredményekből kiderül az is, hogy a Moesin hősokk, valamint a rael gén RNS interferenciával történő csendesítése esetén sejtmagi halmozódást mutat. Mindezek arra utalnak, hogy a sejtmagban a Moesinnek feladata van, ezért munkánk során arra a kérdésre is választ kerestünk, hogy mi a Moesin sejtmagi funkciója, mi a jelentősége a sejtmagi Moesin funkcióinak az állat fejlődése és élete szempontjából.

A Moesin sejtmagi tevékenységének vizsgálatát a többi, sejtmagban megtalálható citoszkeletális fehérjéhez hasonlóan nagyban nehezíti, hogy a citoplazmában esszenciális feladatokat lát el, ezért a magi és citoplazmás funkciói nehezen különíthetők el egymástól. A Moesin esetében ugyan sikerült a sejtmagi lokalizációért felelős peptid szekvenciát meghatároznunk, melynek elrontásával a Moesin magi funkcióit kiiktathatjuk, azonban a Moesin esete mégis speciális, mert a sejtmagban megtalálható Moesin nem az NLS segítségével, hanem a mitózis után, a sejtmag újraszerveződésekor, a kromoszómákhoz kapcsolódva záródik be a sejtmagba (Vilmos és mtsai, 2009). A folyamat az NLS hiányában is végbemegy (Vilmos és mtsai, 2009), és normális körülmények között a fehérje alig hagyja el a sejtmagot (Kristó és mtsai, 2017). Ennek megfelelően, a Moesin NLS szignáljának törlésével nem lehet Moesin-mentes állapotot létrehozni a sejtmagban, így a Moesin sejtmagi funkciójának vizsgálatát egy nukleáris exportszignál (NES) alkalmazásával hajtottuk végre (MoeNES). Ezzel közel Moesin-mentes állapotot tudtunk előidézni a sejtmagban, melyet az előkísérletben a transzgénről termeltetett MoeNES fehérje eloszlása igazolt (19. ábra).

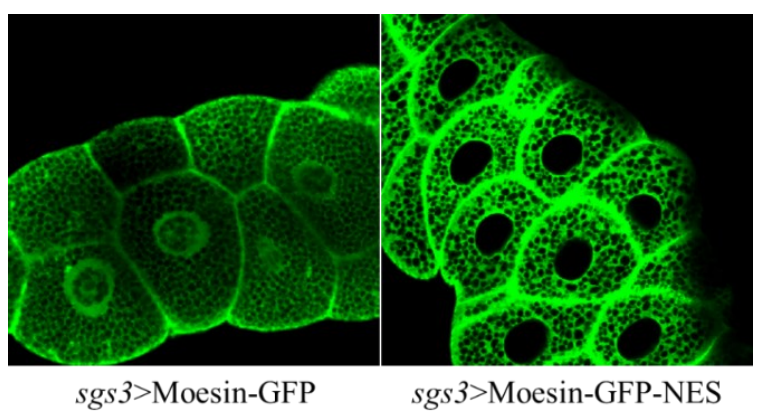

19. ábra Moesin-GFP-NES lokalizációja a Drosophila lárva nyálmirigy sejtjeiben. A vad típusú Moesin kis mennyiségben megtalálható a sejtmagban, míg a Moesin-GFPNES forma egyáltalán nem. A NES-sel felszerelt fehérje ugyanakkor a vad típusúhoz hasonlóan erőteljesen lokalizál a sejtek kortexén található aktin hálózathoz. sgs3: nyálmirigy specifikus promóter. 


\subsubsection{A moe[NES] mutáns Drosophila vonalak létrehozása}

A közel Moesin-mentes sejtmagokat hordozó Drosophila vonal létrehozásához a moesin génbe egy nukleáris exportszignált építettünk a CRISPR-Cas9 rendszerrel, melynek lépéseit a 20. ábra foglalja össze. A CRISPR rendszer a baktériumok és Archeák védekező mechanizmusa az őket megfertőző vírusokkal szemben. A rendszer működési egysége a CRISPR lókusz, melynek átíródását követő, hosszú érési folyamat eredményeként crisprRNS (crRNS) keletkezik. Az érett crRNS a Cas9 nukleázt tartalmazó komplex részeként, a bázispárosodás szabályainak megfelelően kapcsolódik a komplementer idegen DNS-hez, elősegítve annak Cas9 általi szekvencia specifikus hasítását. A CRISPR lókusz szerkezetétől, valamint a crRNS érésétől függően három CRISPR csoportot különböztetünk meg: I. II. és III. típus. (Sorek és mtsai, 2013). A II típusú CRISPR rendszer kevés komponensből áll, ezért ebből adódó könnyü kezelhetősége miatt használják irányított génmódosítási célokra. A génmanipulációs eljárások során a crRNS-t egy úgynevezett guideRNS-sel (gRNS) helyettesítik, mely a crRNS-en felül tartalmaz a crRNS megfelelő éréséhez nélkülözhetetlen transz-ható crisprRNS-t is (tracrRNS) (Carroll és mtsai, 2011).

A gRNS-ek tervezésének első lépéseként a moesin gén megfelelő régiójában Cas9 hasítóhelyeket kerestünk az alábbi kritériumoknak megfelelően: 1. A plazmidról történő megfelelő kifejeződés miatt a kezdő nukleotid G legyen. 2. A kiválasztott szekvencia 3' végét egy NGG triplet határolja. 3. A hasítóhelyek olyan genomi környezetben kerestük (intronikus, valamint a gén utáni nem kódoló régió), hogy a markergén eltávolításakor visszamaradó loxP szekvencia és a 3' végi hasítóhely megváltoztatása ne okozzon változást a moesin gén müködésében. A moe[NES] mutáns készítésének első lépéseként először leteszteltük a megtervezett gRNS-eket. Az elkészített gRNS plazmidokat (Cas9_1; Cas9_2; Cas9_3 és Cas9_4) páronként (Cas9_1+Cas9_3; Cas9_1+Cas9_4; Cas9_2+Cas9_3,

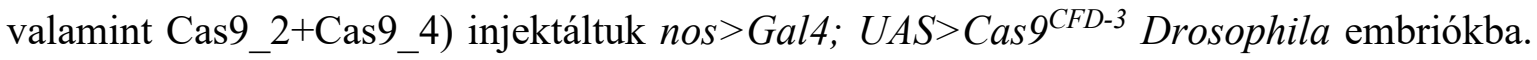
A négy gRNS pár közül a Cas9_2+Cas9_3 kettős rendelkezett a legjobb hatásfokkal, ebben az esetben egyértelmüen azonosítható volt a hasítás következtében létrejövő 1132 bázispár méretű deléciós PCR termék (21. ábra). A vad típusnak megfelelő 2313 bázispáros PCR termék az injektált minták esetében is megtalálható volt, mivel a Cas9 általi hasítás az embrió nem minden sejtjében ment végbe, illetve a PCR reakció során használt DNS templátot öt embrióból izoláltuk. 


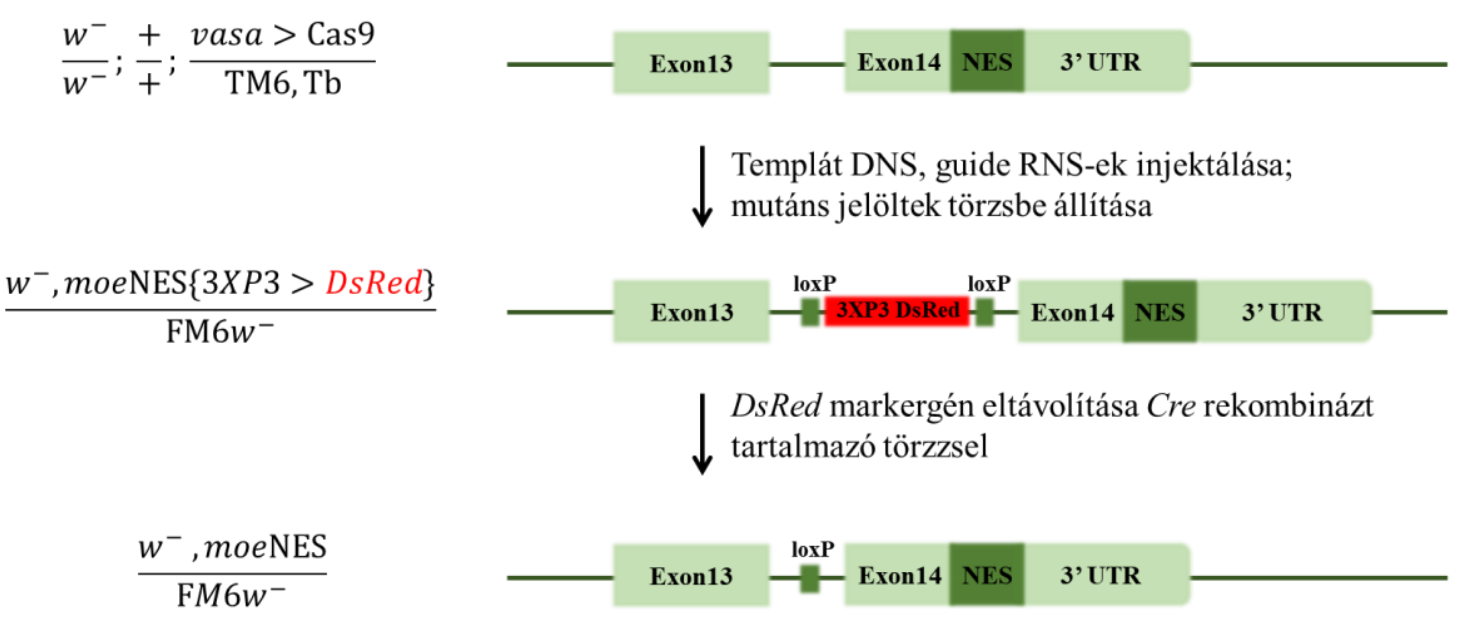

20. ábra NES beépítése a moesin génbe a CRISPR-Cas9 rendszer alkalmazásával. A NES szekvenciát a kódoló szekvencia és a 3' UTR közé építettük be. A mutáns legyek azonosítását követően a beépülést jelző 3 XP3 $>$ DsRed markergént eltávolítottuk a 13. és a 14. exonokat elválasztó intronból.
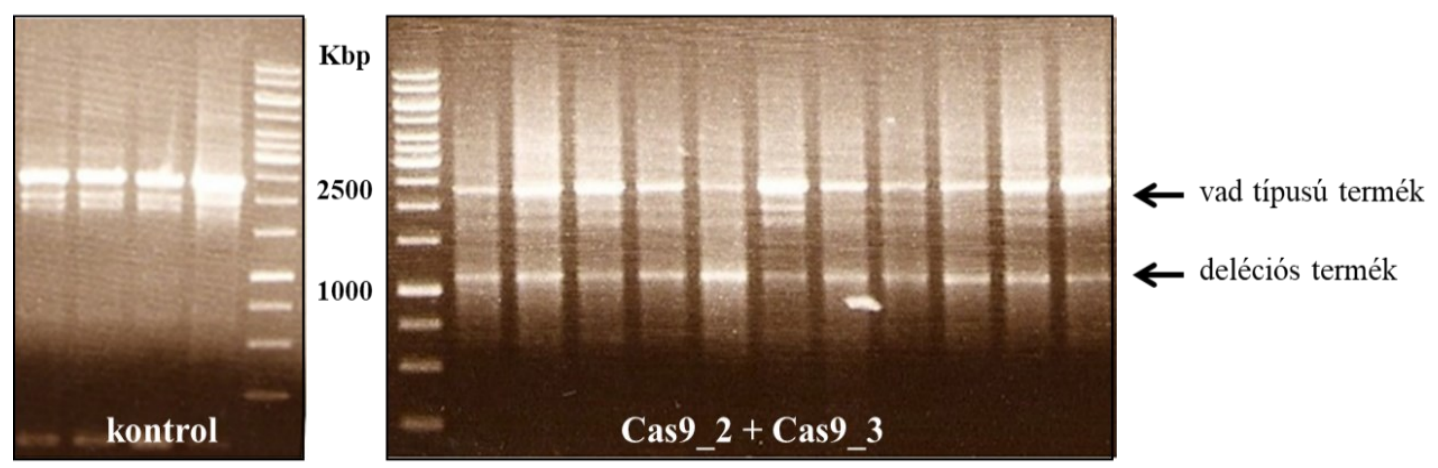

21. ábra A Cas9_2 és Cas9_3 gRNS pár tesztelésének eredménye.

A hasítás során 1132 bp méretü, míg a kontrollban 2313 bp nagyságú vad típusú terméket kaptunk.

A homológ rekombinációs hibajavításhoz templátként szolgáló donor konstruktot az 5 kbp-os moesin génszakaszon végzett három PCR termékből építettük össze (22. ábra). A PCR segítségével a NES szekvenciát a fehérjekódoló rész és a 3' UTR közé építettük be. A két homológiakart egy loxP helyek segítségével eltávolítható, $3 x P 3$ nevü, szemspecifikusan aktív promóterrel rendelkező DsRed markergén választja el, mely lehetővé tette számunkra a mutánsok könnyebb azonosítását, valamint a markergén későbbi eltávolítását. A gRNS, valamint a donor konstruktok injektálását követően a kikelő embriókból négy egymástól független mutáns moe[NES] vonalat alapítottunk. 


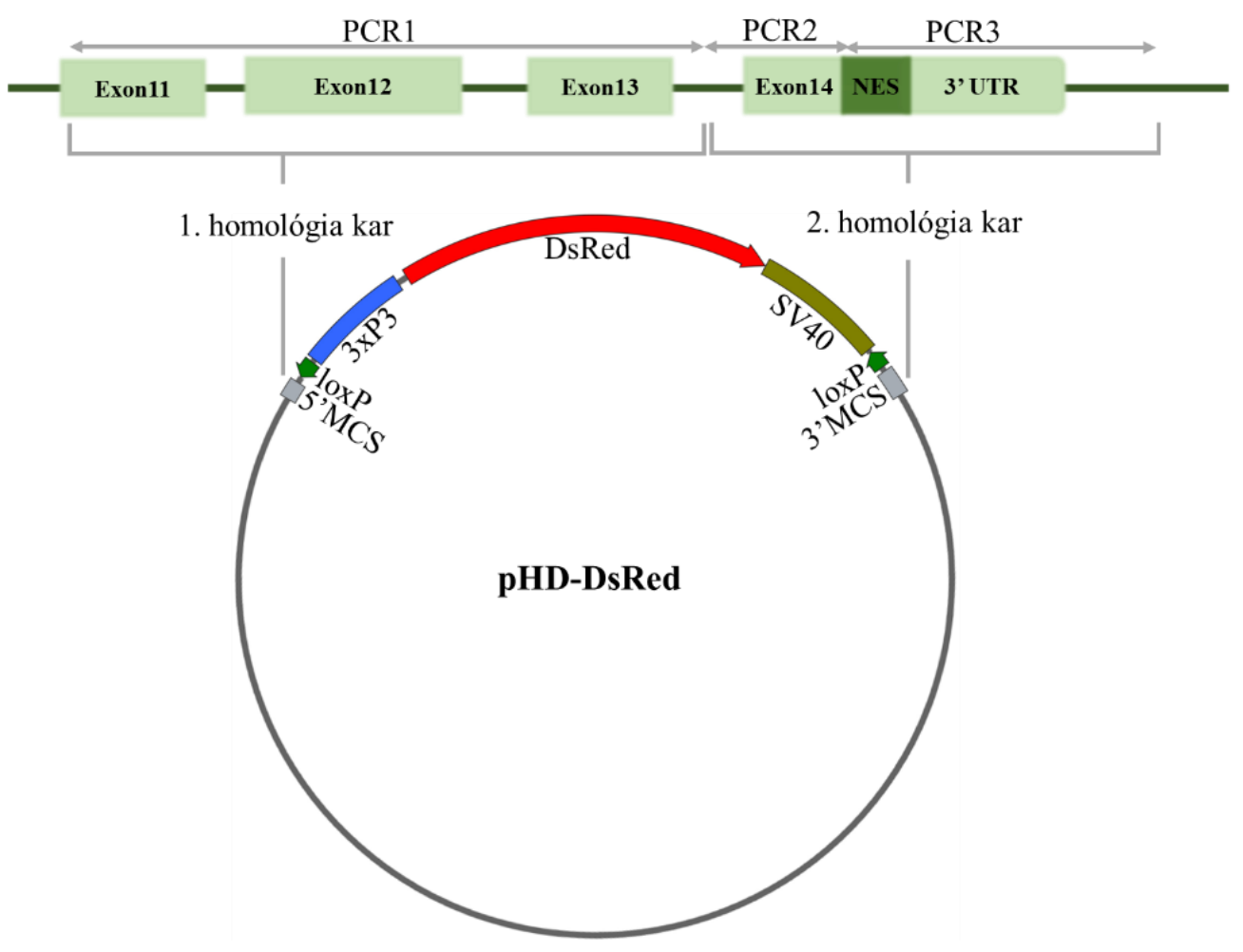

22. ábra A hasítás során templátként szolgáló donor konstrukt felépítése.

A moesin génszakaszt tartalmazó homológiakarokat három PCR termék ligálásából építettük össze. A homológ szakaszokat egymástól a mutáns azonosítását elősegítő loxP helyek által határolt $D s R e d$ markergén választja el. 3xP3: szemspecifikus promóter. MCS: multiklónozó hely.

A mutánsok azonosítását követően a piros fluoreszcens szemszínt okozó markergént (3xP3>DsRed) (23. ábra) eltávolítottuk a Cre rekombinázt tartalmazó transzgenikus törzs alkalmazásával, s így mindössze egy loxP szekvencia maradt a gén utolsó intronjában.
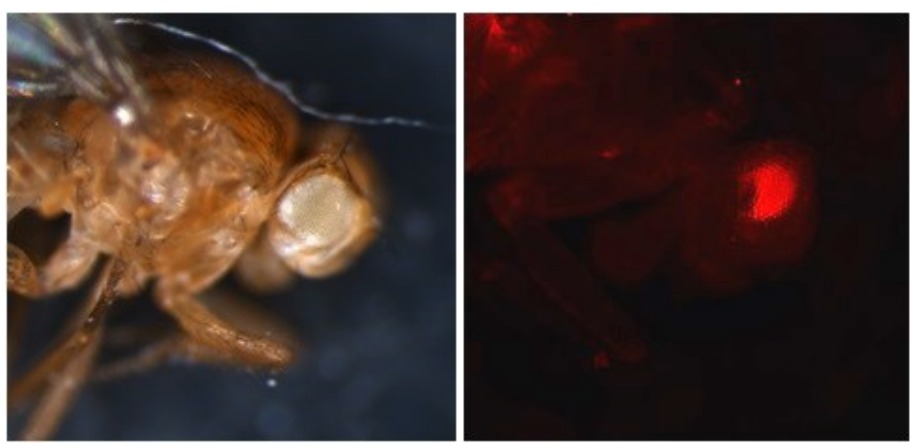

23. ábra A 3xP3>DsRed markergén kifejeződése (piros) a mutáns jelölt szemében. 
A módosított génről képződő moe[NES] mRNS-t ezután RT-PCR-rel és szekvenálással ellenőriztük, és az adatok alapján kijelenthettük, hogy a loxP szekvenciát tartalmazó intron a moe[NES] mRNS érése során hibátlanul eltávolítódik. Az így elkészített moe[NES] vonalakkal lehetőségünk adódott arra, hogy a Moesin sejtmagi hiányából adódó fenotípusok segítségével a fehérje sejtmagi funkcióját a citoplazmás funkcióitól elkülönítve vizsgáljuk.

\subsubsection{A moe[NES] törzs létrehozása}

A munka folyamán a DsRed markergént a moesin gén utolsó intronjában még tartalmazó mutáns vonalak ( $w^{-}$, moe $\left.[\mathrm{NES}][3 x P 3>\mathrm{DsRed}] / \mathrm{FM} 6 w^{-}\right)$esetében letalitást tapasztaltunk, ami felvetette annak lehetőségét, hogy a sejtmagi Moesin az élethez nélkülözhetetlen. A DsRed markergén eltávolításával azonban a letalitás megszünt, jelezve, hogy nem ez a helyzet.

A markergén eltávolításával létrejött moe[NES]/FM6w állatok ugyan életképesek és fertilisek voltak, azonban a további vizsgálatok során kiderült, hogy a Moesin-NES anyai hatású faktorként, domináns módon a nőstények utódainak 100\%-ában sterilitást okoz. Mivel a moesin gén az első (X) kromoszómán található, a moe[NES] allél megtartására és a mutáns törzs létrehozására a moe[NES]DsRed és Cre rekombináz géneket egyaránt tartalmazó hímeket kapcsolt X kromoszómát hordozó nőstényekkel $\left(\mathrm{X}^{\wedge} \mathrm{X} / \mathrm{Y}\right)$ kereszteztük (10. ábra). A kapcsolt X kromoszóma két, közös kromocenterrel rendelkező, teljes hosszúságú első kromoszómát tartalmaz, így együtt öröklődnek, ezért a kapcsolt $\mathrm{X}$ kromoszómát hordozó nőstények hím utódai az Y kromoszómájukat mindig az anyjuktól, míg X kromoszómájukat az apjuktól öröklik. Vagyis a kapcsolt X kromoszómát tartalmazó moe[NES] mutáns törzsek esetében csak a hímek hordozzák a moe[NES] allélt tartalmazó X kromoszómát (moe[NES]/Y), a nőstények nem, így az anyai hatású sterilitás problémája kiküszöbölődik. Ez egyúttal azt is jelenti, hogy a törzs moe[NES] hímjeiben esetleg megjelenő fenotípusok nem anyai hatás következményeként alakulnak ki, vagyis mindegyikük zigotikus eredetü. A kapcsolt X kromoszóma segítségével fenntartott törzs moe[NES]/Y genotípusú hímjei ugyan életképesnek és fertilisnek bizonyultak, azonban a domináns anyai hatású, 100\%-os sterilitás miatt a moe[NES] allélt hordozó nőstényeket csak úgy tudtunk vizsgálni a továbbiakban, ha a moe[NES]/Y hímeket minden kísérletben vadtípusúnak tekinthető $\left(w^{1118}\right)$ vagy moesin null allélt $\left(m o e^{\mathrm{G} 0415}\right)$ hordozó nőstényekkel kereszteztük. Ezután a kikelő, az első esetben a moe[NES]-re nézve heterozigóta, míg a második esetben csak moe[NES]-t expresszáló nőstény utódokat vizsgálhattuk (24. ábra). 


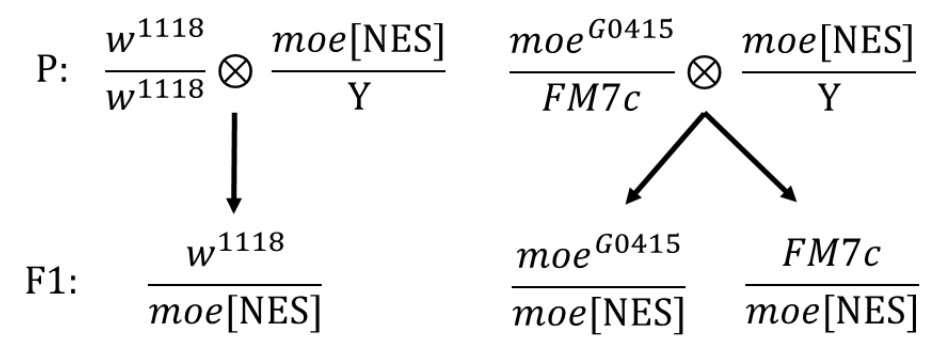

\section{4. ábra. A kísérletekben használt különféle moe[NES] genotípusú nőstények előállítása.}

Az első keresztezésből csak moe[NES] heterozigóta nőstény utód kel ki, míg a másodikban van lehetőség kizárólag moe[NES] allélt kifejező nőstények vizsgálatára is. A második keresztezés nőstény utódai közül a vad típusú Moesint expresszáló nőstény (moe[NES]/FM7c) a balanszer kromoszómán lévő markergén (Bar) segítségével megkülönböztethető.

\subsubsection{A moe[NES] mutánsok fenotípusai}

A moe[NES] mutáns legyek esetében számos fenotípust megfigyeltünk, melyek egy része zigotikus, más része anyai hatás eredményeként alakult ki (25. ábra). Az anyai hatású fenotípusok a moe[NES] nőstények utódainál jelennek meg először, az utódok genotípusától függetlenül. Az így azonosított anyai hatású fejlődési rendellenességek főként a test poszterior részét érintették: tergit elváltozásokat és csökevényes ivarszerveket, továbbá az életképesség csökkenését és sterilitást észleltünk. A zigotikus hatású fenotípusok ezzel szemben a kapcsolt X kromoszómát hordozó nőstények segítségével fenntartott törzsek moe[NES] mutáns hímjeiben is megjelennek. Ilyen fenotípus a csökkent mászási és hőtürő képesség, az élethossz csökkenése, a genitália rotációja, illetve a sötétebb és durvább szem, valamint a különféle szárnyfejlődési hibák.

Annak megerősítésére, hogy az anyai hatású domináns sterilitás kialakulása valóban a MoeNES fehérjéhez, s annak domináns negatív (antimorf), a vad típusú Moesinnel ellentétes hatásához köthető, a MoeNES fehérjét túltermeltettük a nos $>\mathrm{Gal} 4$ és UASp $>$ MoeNES vonalak keresztezésével létrehozott UASp $>$ MoeNES/nos $>$ Gal4 genotípusú nőstények ivarvonalában. A nőstényekben a két kópiában jelenlevő, vad típusú moesin gén ellenére a MoeNES fehérje hatására az utódok 98\%-os ivarsejthiányos fenotípust mutattak, ami egyértelmüen igazolja a NES motívum antimorf hatását, és azt, hogy az ivarsejtek elvesztéséhez elegendő a MoeNES fehérje jelenléte az anya ivarvonalában. Ugyanakkor az utódokban fejlődési rendellenességeket nem tapasztaltunk. 


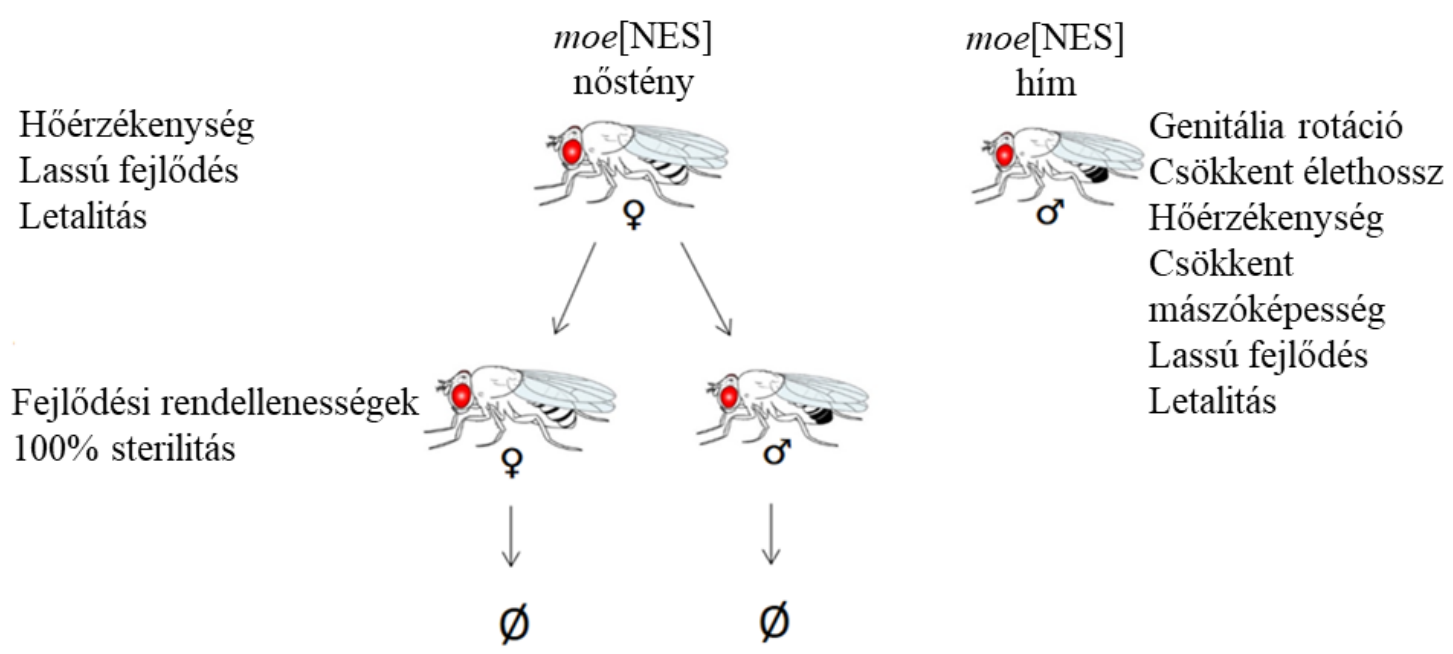

25. ábra A moe[NES] mutáns legyekben megfigyelt fenotípusok.

A megfigyelt fenotípusok egy része anyai hatás eredménye miatt alakult ki, melyek a következők: tergitet érintő elváltozások, részben a letalitás és sterilitás. A leírt fenotípusok másik része zigotikus eredetű: csökkent mászási és hőtürő képesség, genitália rotáció, illetve részben a letalitás.

\subsubsection{A látható fenotípusok}

A moe[NES] mutánsok utódaiban megfigyelhető fejlődési rendellenességek főként a test poszterior részére terjednek ki, és ezek a következők: hím genitália rotációja (26.A ábra), csökevényes ivarszervek (26.B ábra), tergitet (26.C3 ábra) és szárnyat (26.D ábra) érintő elváltozások, valamint sötétebb és durvább felszínű szem (26.E ábra). Ugyanakkor megfigyeltük a hímek esetében a külső ivarszerv teljes hiányát (26.C2 ábra), illetve extra szőrök megjelenését (26.C1 ábra) és megváltozott tergit pigmentációt (26.C4 ábra) is. A tergitelváltozások, illetve a csökevényes ivarszervek akkor figyelhetők meg, amikor az anya legalább egy példányban hordozza a moe[NES] allélt. A moe[NES]-re nézve homozigóta $\left(m o e[\mathrm{NES}] / \mathrm{moe}^{\mathrm{G} 0415}\right)$, illetve heterozigóta (moe[NES]/FM7-GFP) nőstények utódainak vizsgálata részletesebb jellemzést eredményezett a tergitet érintő elváltozásokat, valamint a genitália rotációt illetően. 
A

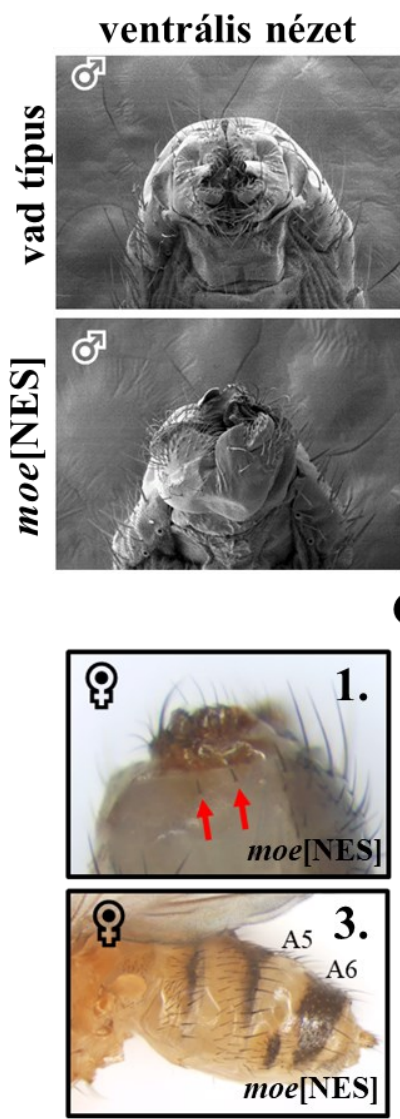

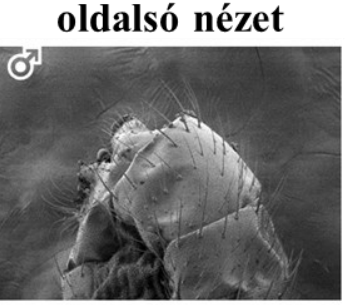

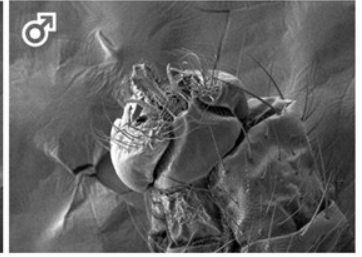

C
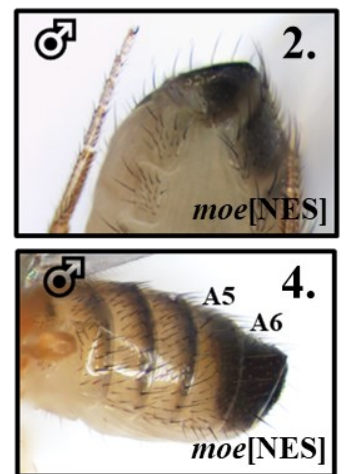

B
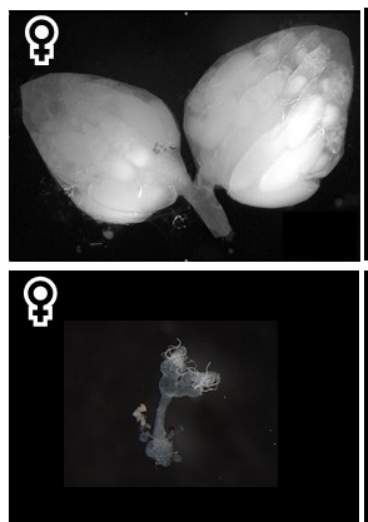

D

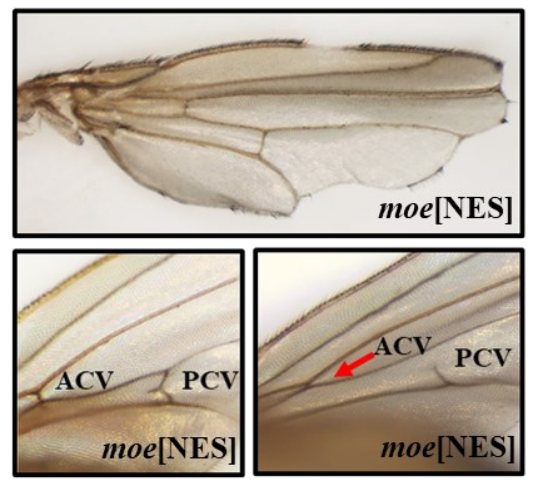

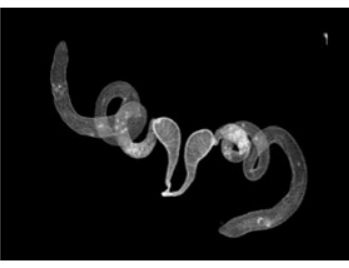

कా

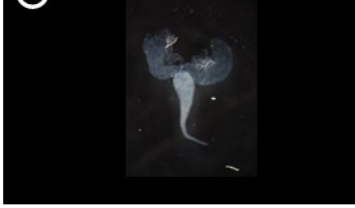

$\mathbf{E}$

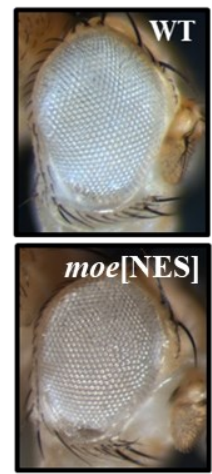

26. ábra A moe[NES] mutáns legyek utódai által mutatott fejlődési rendellenességek. ACV: anterior keresztvéna, PCV: poszterior keresztvéna, WT: vad típus.

Mivel a moe[NES]/FM7-GFP nöstények utódai közül csak a moe[NES]/Y hím utódok mutattak genitália rotációt, míg az FM7-GFP/Y hímek egyike sem, illetve a moe[NES]/Y hemizigóta hímekben az anyától függetlenül megjelenik a fenotípus, ezért kijelenthető, hogy a genitália rotáció kizárólag zigotikus eredetű (27. ábra). A tergitet érintő elváltozások esetében pedig megállapítható, hogy ezek részben anyai eredetủek, mivel a w',moe[NES]/FM7-GFP nőstények FM7-GFP/Y hím utódai között is megfigyelhetők ilyen típusú fejlődési rendellenességek. Továbbá az elváltozások anyai hátterét igazolja az a tény is, hogy azon moe[NES]/moe[NES] utódokban, ahol az anya egyetlen müködő moesin allélja a moe $[\mathrm{NES}]$ volt $\left(w^{-}, m o e[\mathrm{NES}] / m o e^{\mathrm{G} 0415}\right)$, sokkal nagyobb arányban fordulnak elő tergitet érintő hibák, mint a moe[NES]/FM7-GFP nőstények utódai esetében, ahol a vad típusú moesin allél részben képes menekíteni ezt a MoeNES fehérje okozta fenotípust. Ugyanakkor a tergitet érintő fejlődési hibáról elmondható, hogy az anyai hatás mellett zigotikus háttérrel is rendelkezik, mivel a moe[NES] allélt is hordozó utódokban gyakoribb volt a tergitelváltozás. Továbbá ezekből az adatokból az is megállapítható, hogy a mutáció nem 
neomorf vagy hipermorf jellegü, mivel a vad típusú moesin részben képes menekíteni a moe[NES] okozta elváltozásokat.

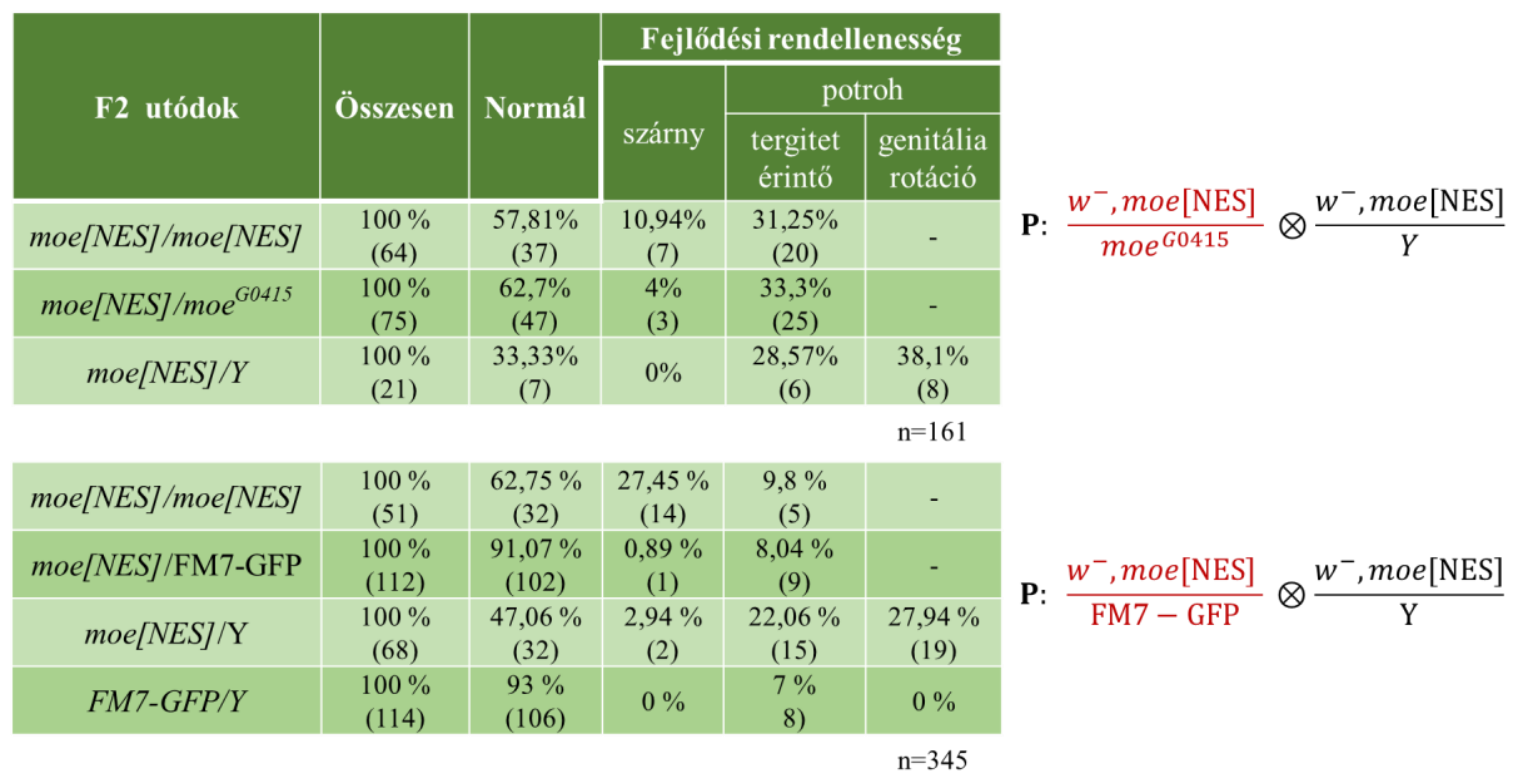

27. ábra Zigotikus és anyai hatású fenotípusok elkülönítése.

A tergitet érintő elváltozások részben anyai, részben zigotikus háttérrel is rendelkeznek. A genitália rotáció ugyanakkor egyértelmüen zigotikus hátterü, mivel az anyától függetlenül jelenik meg a moe[NES]/Y hemizigóta hímekben.

A kapcsolt X kromoszómát tartalmazó mutáns vonalakból származó moe[NES]/Y hímek esetében szárnyat érintő fejlődési rendellenességet, valamint genitália rotációt figyeltünk meg, melyek összesített adatait a 28. ábra tartalmazza. A kísérletekhez elkészítettük a kapcsolt $\mathrm{X}$ kromoszómát tartalmazó törzs olyan változatát is, ahol az $\mathrm{Y}$ kromoszómát lecseréltük egy, a moesin közvetlen genomi környezetét tartalmazó Y kromoszómára (Dp(1:Y)619). Az utódok fenotipikus vizsgálata alapján elmondható, hogy a genitália rotáció gyakorisága a duplikációs törzs esetében kevesebb, mint a felére (38\%) csökkent, vagyis menekítette a MoeNES okozta fenotípust. Ez egyúttal azt is jelenti, hogy a genitália rotációs fenotípus a MoeNES-hez köthető és annak funkcióvesztése okozza. 


$$
\frac{w^{-}, m o e[N E S]}{\mathrm{Y}} \otimes \frac{\hat{\mathrm{X}}}{\mathrm{Y}}
$$

\begin{tabular}{|c|c|c|c|c|c|}
\hline \multirow{2}{*}{ Utódok genotípusa } & \multirow{2}{*}{ Összesen } & \multirow{2}{*}{ Normál } & \multicolumn{3}{|c|}{ Fejlődési rendellenesség } \\
\hline & & & szárnyat érintő & genitália rotáció & $\begin{array}{c}\text { szárny és } \\
\text { genitália rotáció }\end{array}$ \\
\hline moe $[N E S] / Y ;+/+$ & $145 \mathrm{db}$ & $63,45 \%(92)$ & $1,38 \%(2)$ & $32,41 \%(47)$ & $2,76 \%(4)$ \\
\hline$\widehat{X X} / Y ;+/+$ & $186 \mathrm{db}$ & $100 \%(186)$ & - & - & - \\
\hline \multicolumn{6}{|c|}{$\frac{w^{-}, m o e[N E S]}{\mathrm{Y}(D p M o e)} \otimes \frac{\hat{\mathrm{XX}}}{\mathrm{Y}(\text { DpMoe })}$} \\
\hline moe [NES]/Y (DpMoe) & $171 \mathrm{db}$ & $83,63 \%(143)$ & $2,34 \%(4)$ & $12,28 \%(21)$ & $1,75 \%(3)$ \\
\hline$\hat{X X} / Y(D p M o e)$ & $360 \mathrm{db}$ & $100 \%(360)$ & - & - & - \\
\hline
\end{tabular}

\section{8. ábra A kapcsolt X kromoszómákat tartalmazó moe[NES], valamint moesin duplikációs törzs fejlődési rendellenességeinek gyakorisága.}

A kísérlet adatai alapján elmondható, hogy a duplikációt hordozó törzs képes menekíteni a moe[NES] okozta genitália rotációt.

A következőkben más megközelítéssel is vizsgáltuk, hogy a genitália rotáció valóban a Moesin sejtmagi hiányának a következménye-e vagy esetleg például egy másodlagos háttérmutáció okozza. Ehhez moesin null mutáns állatokat menekítettünk transzgénről termeltetett Moesin-NES fehérjével. A kísérletben az általunk létrehozott UASt>MoeNESGFP transzgenikus törzset használtuk, melynek kifejeződését egy Gal4 enhancer csapdázó mutáns, a moe[PG26] jelü törzs Gal4 forrása biztosította. A moe[PG26] allél előnye, hogy a Gal4 fehérje expresszióját a moesin promóter irányítja és egyben null mutáns is a moesin génre nézve. A moe[PG26]/Y; UASt>MoeNES-GFP hímek 28,57\%-a (14 db) mutatott genitália rotációt (29. ábra), ami gyakorlatilag megegyezett a kapcsolt X-es törzs esetében megfigyelt értékkel (32,41\%). Mindezen eredmények alapján kijelenthetjük, hogy a genitália rotáció valóban a Moesinhez köthető, és annak sejtmagi hiánya okozza. 


$$
\text { P: } \frac{\text { moesin }[P G 26]}{F M 0} \otimes \frac{U A S t>M o e N E S-G F P}{\text { TM3 }}
$$

\begin{tabular}{|l|c|}
\hline Utódok genotípusa & \\
\hline moesin[PG26]/+; UASt>MoeNES-GFP/+ & $17,8 \%(134)$ \\
\hline moesin[PG26]/+; +/TM3 & $18,8 \%(142)$ \\
\hline FM0/+; UASt $>$ MoeNES-GFP/+ & $21,4 \%(161)$ \\
\hline FM0/+; +/TM3 & $13,4 \%(101)$ \\
\hline moesin[PG26]/Y; +/TM3 & - \\
\hline moesin[PG26]/Y; UASt>MoeNES-GFP/+ & $6,5 \%(49)$ \\
\hline FM0/Y; UASt>MoeNES-GFP/+ & $13 \%(98)$ \\
\hline FM0/Y; +/TM3 & $9,1 \%(69)$ \\
\hline & $\mathrm{n}: 754 \mathrm{db}$ \\
\hline
\end{tabular}

\section{9. ábra A genitália rotáció gyakorisága a moe[PG26]/Y; UASt $>$ MoeNES-GFP/+ hímekben.}

Az ilyen hímek 28,57\%-a mutatott genitália rotációt, mely azt bizonyítja, hogy a mutáció valóban a moesin génhez kapcsolható, nem a NES beépítése során létrejött másodlagos hatás eredménye.

A következőkben azt vizsgáltuk, hogy a moe[NES]/Y hímeket érintő genitália rotáció kapcsolható-e valamilyen Moesin formához, így nyerve információt a mutáció jellegéröl. A vizsgált Moesin formák a következök voltak: 1 . UASp $>$ MoeKN-GFP forma, melynél a PIP 2 kötésért felelős PATCH kötőhely lizinjeinek aszparaginra történt módosításával egy konstitutívan inaktív fehérje jön létre. 2. UASp $>M_{0} T_{559} \mathrm{~A}-\mathrm{GFP}$ fehérje esetében az aktivitásért felelős 559. pozícióban lévő treonint változtatták alaninra, mellyel egy defoszforilált inaktív fehérje képződik. 3. UASp $>M_{\text {MoeT }}{ }_{59} \mathrm{D}-\mathrm{GFP}$ forma esetében az aktivációs treonint aszparaginsavra cserélték, így egy folyamatosan aktív állapotban lévő fehérjét kapunk. Az egyes UAS transzgének kifejeződését a moe[PG26] Gal4 forrással biztosítottuk. Érdekes módon, míg a konstitutívan inaktív MoeKN gyakorlatilag nem, az állandó aktivációs állapotot mutató $\mathrm{MoeT}_{559} \mathrm{D}$ forma pedig csak nagyon kis mértékben volt képes menekíteni a moe[PG26] null mutációt (30. ábra), addig az inaktív MoeT ${ }_{559} \mathrm{~A}$ forma jól menekítette a letalitást (31. ábra). A kísérlet során érdekes megfigyelés volt, hogy az elenyészően kis számban kelt moe[PG26]/Y; UASp>MoeT ${ }_{559} \mathrm{D}-\mathrm{GFP} /+$ menekített hím legyek minden esetben genitália rotációt mutattak. 


$$
\mathbf{P}: \frac{\operatorname{moesin}[P G 26]}{F M 0} \otimes \frac{U A S p>M o e K N-G F P}{\mathrm{TM} 3, S b, \text { Ser }}
$$

\begin{tabular}{|l|c|}
\hline Utódok genotípusa & \\
\hline moesin[PG26]/+; UASp $>$ MoeKN-GFP/+ & $21 \%(142)$ \\
\hline moesin[PG26]/+; +/TM3,Sb,Ser & $17,3 \%(117)$ \\
\hline FM0/+; UASp>MoeKN-GFP/+ & $21,3 \%(144)$ \\
\hline FM0/+; +/TM3,Sb,Ser & $21,2 \%(143)$ \\
\hline moesin[PG26]/Y; +/TM3,Sb,Ser & - \\
\hline moesin[PG26]/Y; UASp $>M o e K N-G F P /+$ & $0,2 \%(1)$ \\
\hline FM0/Y; UASp $>$ MoeKN-GFP/+ & $11,2 \%(76)$ \\
\hline FM0/Y; +/TM3,Sb,Ser & $7,8 \%(53)$ \\
\hline & $\mathrm{n}: 676 \mathrm{db}$ \\
\hline
\end{tabular}

$$
\mathbf{P}: \frac{\operatorname{moesin}[P G 26]}{F M 0} \otimes P\left\{U A S p>M o e T_{559} D-G F P\right\}
$$

\begin{tabular}{|c|c|}
\hline Utódok genotípusa & \\
\hline moesin[PG26]/+; $\left\{\right.$ UASp $\left.>M_{\text {MoeT }} T_{559} D-G F P\right\} /+$ & $34,3 \%(111)$ \\
\hline FM0/+; P $\left\{U A S p>M o e T_{559} D-G F P\right\} /+$ & $35,5 \%(115)$ \\
\hline moesin[PG26]/Y; $P\left\{U A S p>M o e T_{559} D-G F P\right\} /+$ & $1,5 \%(5)$ \\
\hline FM0/Y; P\{UASp $>$ MoeT $\left._{559} D-G F P\right\} /+$ & $28,7 \%(93)$ \\
\hline
\end{tabular}

n: $324 \mathrm{db}$

30. ábra A MoeKN és MoeT559D izoformák menekítőképessége.

A menekítési kísérletekböl kiderül, hogy a MoeT ${ }_{559} \mathrm{D}$, mely állandó aktív formának tekinthetö, illetve a PIP 2 kötésre képtelen MoeKN formák nem képesek menekíteni a moe[PG26] null mutációt.

A moe[NES] mutáció genitália rotációt okozó hatásáról ezek alapján az feltételezhető, hogy hasonló negatív hatással rendelkezik, mint az aktív MoeT ${ }_{559} \mathrm{D}$ forma. Ennek egyik lehetséges magyarázata, hogy a MoeNES fehérje túlmüködése következtében az aktin citoszkeleton szerveződése zavart szenved. Ugyanakkor azonban a dolgozatomban később részletezett kísérleteink alapján egyértelmüvé válik, hogy a moe[NES] legyekben az aktin citoszkeleton épsége nem sérült, valamint hogy a MoeNES fehérje a citoplazmában megfelelően aktiválódik és lokalizál. A genitália rotáció megjelenésének másik lehetséges magyarázata lehet a Moesin sejtmagi funkciójának a zavara. Ebben az esetben a moe[NES] legyekben a Moesin sejtmagi hiánya, míg a $\mathrm{MoeT}_{559} \mathrm{D}$ forma esetében az állandó foszfomimetikus állapot okozza a fenotípus megjelenését, mivel a folyamatosan aktív állapot következtében sejtmagi importja gátlódik és/vagy nem képes ellátni sejtmagi funkcióját. 
Az előzőkkel ellentétben, az irodalomban inkatív formának tekintett MoeT ${ }_{559} \mathrm{~A}$ forma meglepő módon képes menekíteni a moe[PG26] null mutációt: moe[PG26]/Y; UASp $>M_{0 e} T_{559} A-G F P$ genotípusú legyek életképesek, nem mutatnak genitália rotációt, valamint közel azonos gyakoriságban kelnek, mint a vad típusúnak tekinthető FM0/Y; UASp $>M_{0 o e T}{ }_{559} A-G F P$ utódok (31. ábra).

$$
\text { P: } \frac{\operatorname{moesin}[P G 26]}{F M 0} \otimes\left\{U A S p>M o e T_{559} A-G F P\right\}
$$

\begin{tabular}{|c|c|}
\hline Utódok genotípusa & \\
\hline moesin[PG26]/+; P\{UASp $\left.>M_{0 o e} T_{559} A-G F P\right\} /+$ & $26,9 \%(150)$ \\
\hline$F M 0 /+; P\left\{U A S p>M o e T_{559} A-G F P\right\} /+$ & $25,8 \%(144)$ \\
\hline moesin[PG26]/Y; $P\left\{U A S p>M o e T_{559} A-G F P\right\} /+$ & $21,1 \%(118)$ \\
\hline$F M 0 / Y ; P\left\{U A S p>M o e T_{559} A-G F P\right\} /+$ & $26,2 \%(146)$ \\
\hline
\end{tabular}

31. ábra A MoeT 559A Moesin forma menekítőképessége.

A MoeT 559 A-GFP fehérje képes menekíteni a moesin null mutációt. A moe[PG26]/Y; $\mathrm{P}\{\mathrm{UASp}>$ MoeT559A-GFP $\} /+$ legyek közel azonos arányban keltek, mint a többi genotípus osztály.

Az eredmények alapján elmondható, hogy a hímek genitália rotációját valószínüleg a Moesin csökkent sejtmagi mennyisége okozza.

\subsubsection{A moe[NES] mutánsok élettani jellemzése}

Már a kísérletek kezdetén észrevettük a moe[NES] legyek gyenge, lassú mászóképességét, valamint a hőmérséklettel szembeni érzékenységét. A továbbiakban ezért a moe[NES] mutáció következményeinek megismerését célzó élettani vizsgálatokat végeztünk a mutáns legyeken, továbbá tanulmányoztuk, hogy a MoeNES milyen hatással van az embriók és a kifejlett legyek életképességére.

A moe[NES] mutáns nöstények petehozama

A továbbiakban azt vizsgáltuk, hogy a moe[NES] mutáció milyen hatással van a $m o e^{\mathrm{G} 0415} / m o e[\mathrm{NES}]$, illetve moe[NES] $/ w^{1118}$ nőstények petehozamára (32. ábra). Eredményül azt kaptuk, hogy a mutáns legyek által lerakott peték mennyisége megegyezik a kontroll legyek esetében mért értékekkel. Ebböl arra következtethetünk, hogy a moe[NES] mutáció a petehozamra nincs hatással. 


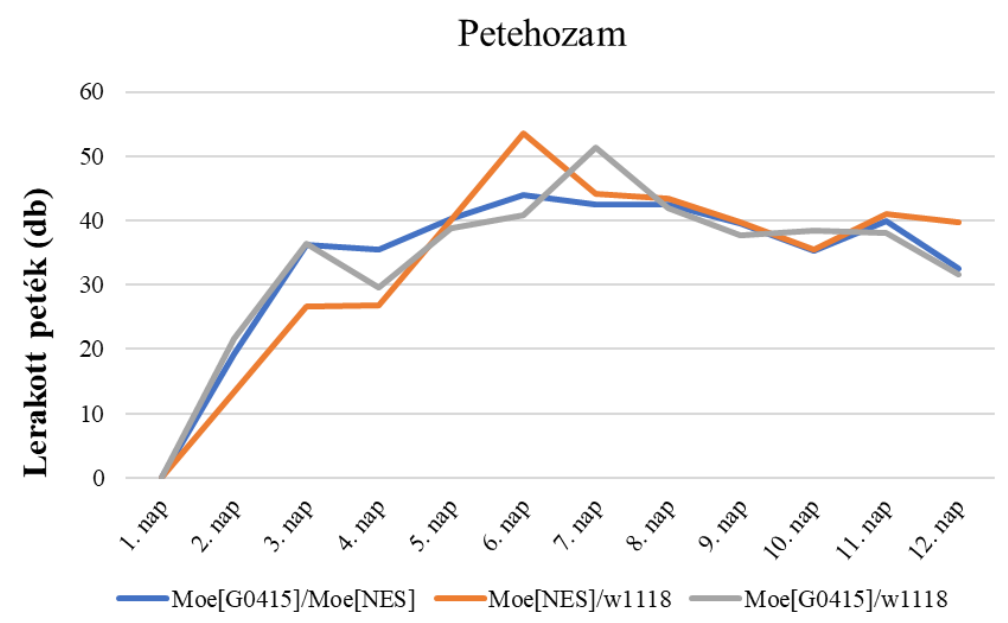

32. ábra A moe $\mathrm{G0415} / \mathrm{moe}[\mathrm{NES}]$ nőstények petehozama.

A mutáns nőstények petehozama a kontroll csoportokkal megegyező mértékű.

A moe[NES] nöstények embrióinak életképessége

A következőkben megvizsgáltuk a moe[NES]/moe $e^{\mathrm{G} 0415}$ mutáns anyáktól származó embriók életképességét (33. ábra). Az adatok alapján elmondható, hogy a mutáns vonal esetében a letalitás mértéke $74 \%$, míg a vad típus esetében $12 \%$ volt, ami azt jelzi, hogy a

\begin{tabular}{|c|c|c|c|c|}
\multirow{2}{*}{ Genotípus } & \multicolumn{3}{|c|}{ Embriók } \\
\cline { 2 - 4 } & \multirow{2}{*}{ kikelt } & \multicolumn{2}{|c|}{ elpusztult } & \multirow{2}{*}{ összes embrió } \\
\cline { 3 - 4 } & & kései pete & korai pete & $150 \mathrm{db}$ \\
\hline$w^{1118}$ & $88 \%$ & $2,7 \%$ & $9,3 \%$ & $200 \mathrm{db}$ \\
\hline moe $[N E S] /$ moe $^{G 0415}$ & $26 \%$ & $18 \%$ & $56 \%$ & \\
\hline
\end{tabular}

33. ábra Embriók életképességének vizsgálata.

A $m o e[\mathrm{NES}] / m_{0} e^{\mathrm{G} 0415}$ nőstények embrióinak letalitása $74 \%$.

mutáns nőstények által lerakott peték 3/4-e életképtelen. Továbbá azt is megfigyeltük, hogy a nőstények életkorának emelkedésével csökken az embriók életképessége, mely egy vad típusú moesin alléllal részlegesen menekíthető (34. ábra). 


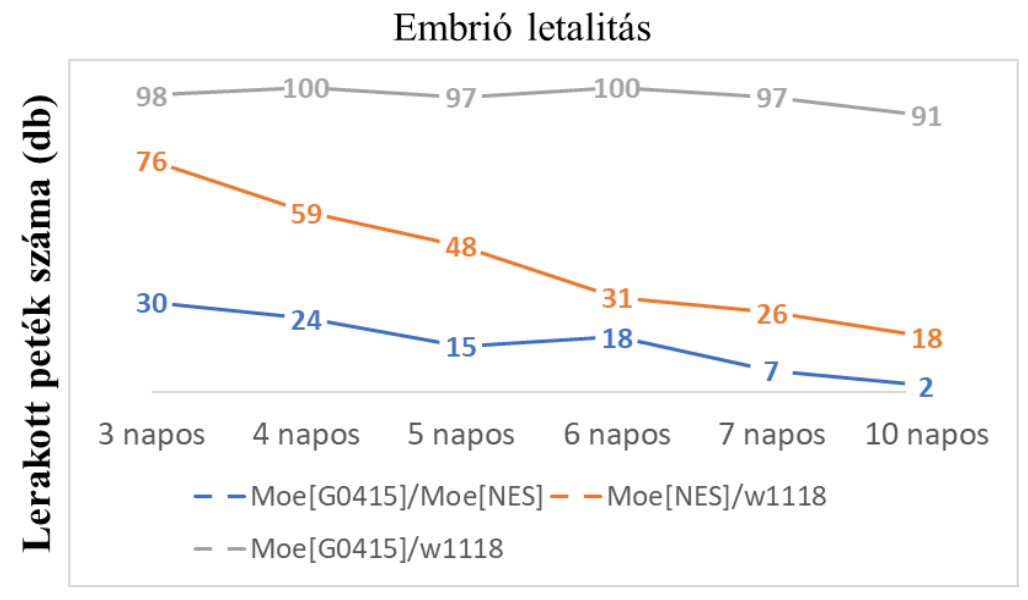

34. ábra Embriók letalitásának a meghatározása.

A nőstények életkorának növekedésével az embriók letalitása is nő. A fenotípus részben menekíthető a vad típusú moesin alléllal.

A moe[NES] mutánsok embriókor utáni életképessége

Az embriók életképességének csökkenése mellett lárvális és báb kori letalitást is azonosítottunk, melyek a vad típusú moesin alléllal teljes mértékben menekíthetők voltak, vagyis a moe[NES] okozta letalitás nem domináns hatás következtében alakult ki, hanem a Moesin feltehetően sejtmagi hiányából adódó funkcióvesztés eredményeként. Csökkent élethosszt $25^{\circ} \mathrm{C}$-on a moe $[\mathrm{NES}] / \mathrm{Y}$ hímek esetében tapasztaltunk, míg a moe $[\mathrm{NES}] /$ moe $^{\mathrm{G} 0415}$ mutáns nőstények élettartama a kontroll csoportéval közel megegyező volt (35. ábra). 

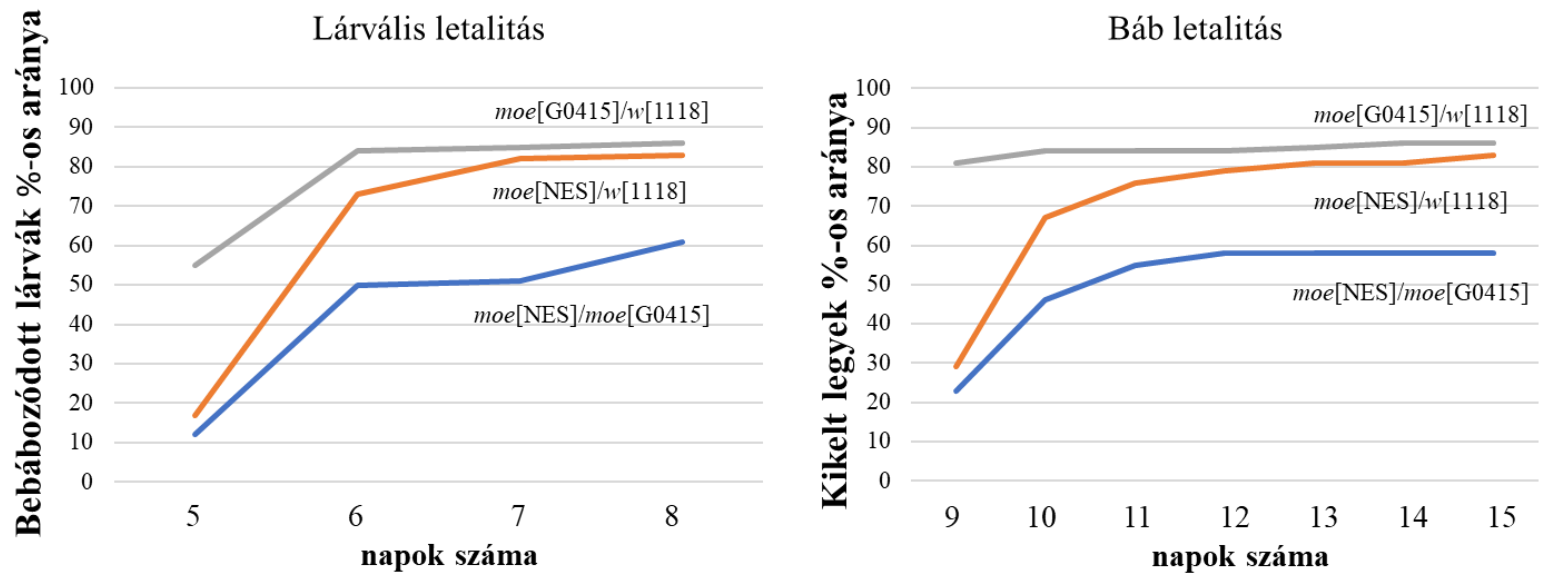

Élethossz $\left(25^{\circ} \mathrm{C}\right)$

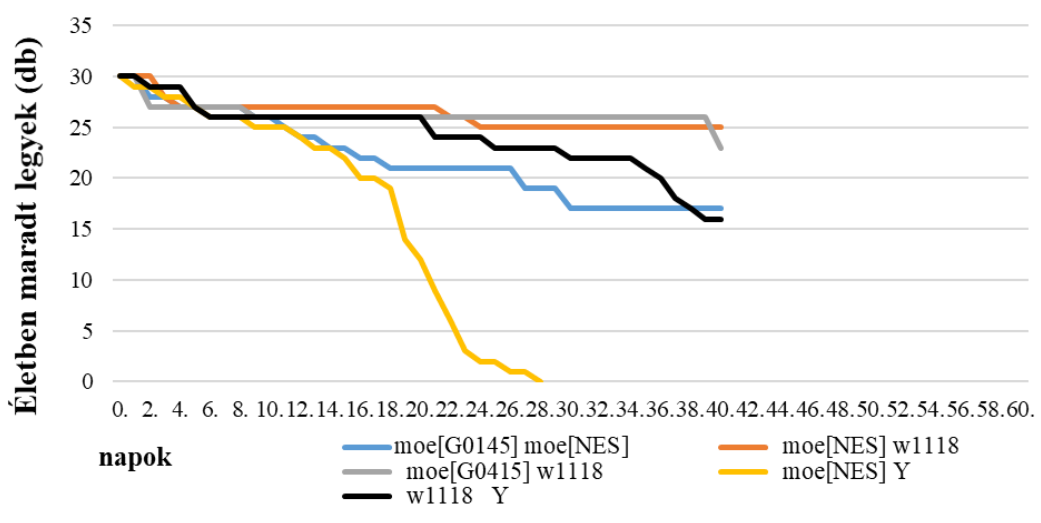

35. ábra A moe[NES] mutánsok életképessége.

A moe[NES] mutáció lárvális és báb letalitást, valamint a hímek esetében csökkent életképességet okoz.

A moe[NES] mutánsok éhezési stressz türése

A következőkben a petehozam mérésével az éhezési stressz türését vizsgáltuk oly módon, hogy a legyeket minden nap friss táptalajara helyeztük, majd a 4. és az 5. napon megvontuk tőlük a táplálékot, és számoltuk a nőstények által lerakott petéket. A diagramon (36. ábra) leolvasható, hogy a nőstények az éhezés következtében csökkent petehozamot mutattak, majd normál táptalajra való visszatérés során a petehozam az éhezés előtti állapotra visszaállt. A kísérletben a moe[NES] nőstényekben az éhezésre adott válaszreakció a vad típussal megegyező volt, a mutáns legyek a vad típushoz nagyon hasonló petehozamra képesek. 


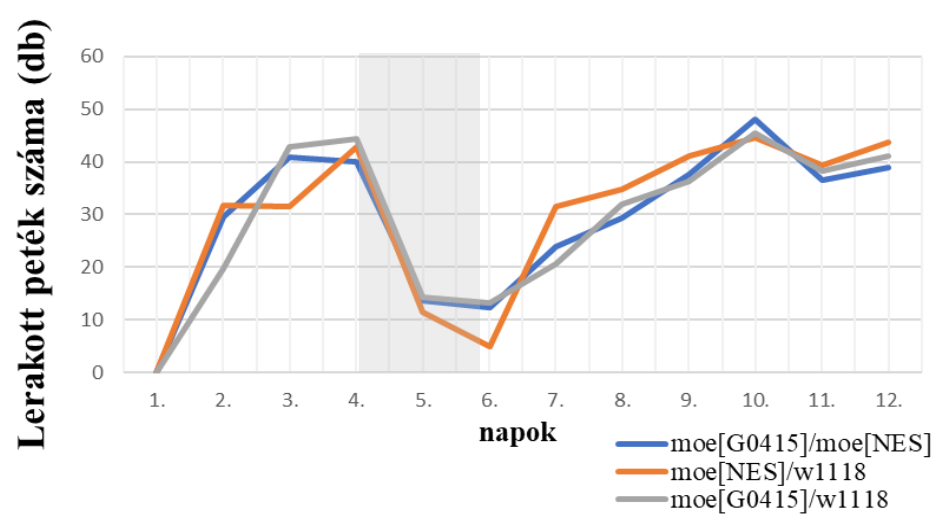

36. ábra A mutáns nőstények éhezési stressztürésének vizsgálata.

A $m o e^{\mathrm{G} 0415} /$ moe [NES] legyek hasonló módon reagálnak az éhezésre, mint a kontroll legyek, a Moesin sejtmagi hiánya nem befolyásolja az éhezésre adott válaszreakciókat. Az éheztetés időszaka szürke hátérrel kiemelve.

A moe[NES] mutánsok mászóképessége

A moe[NES] törzsek esetében megfigyeltük, hogy a mutáns hímek egy része lassan, vagy egyáltalán nem képes a fiola függőleges falán felmászni. Ennek megfelelően felmértük a mutáns hímek motoros funkcióinak épségét, melynek legegyszerübb vizsgálati módja az ún. mászási teszt alkalmazása. A teszt eredményéül azt kaptuk, hogy a moe[NES]/Y mutáns hímek szignifikánsan gyengébben teljesítenek a mászóteszten: 13\%-uk volt képes 8 másodperc alatt a teljes táv megtételére, míg a vad típusnál ez az arány $48 \%$ volt (37.A ábra). A vizsgálatot elvégeztük idősebb, 1 hetes állatokkal is, ám az öregedéssel a mászás képessége jelentősen nem romlott a kontroll állatokhoz viszonyítva, ahol a vad típusú legyek 59\%-a, míg a mutáns legyek 10\%-a volt képes azonos idő alatt megtenni a teljes távot. A tesztet nőstényeken is elvégezve azt kaptuk, hogy a moe[G0415]/moe[NES] legyek körülbelül 70\%-a képes volt a teljes táv megtételére, hasonlóan a kontrollként használt moe[G0415]/w[1118] nőstényekhez. Egy hetes nőstényekkel megismételve a kísérletet hasonló eredményt kaptunk, mindkét genotípusból a legyek közel 60\%-a tette meg a 15 cmes távot. Ezek alapján megállapítható, hogy a mutáns hímekkel ellentétben, a moe[NES] nőstényeknél nem áll fenn a motoros funkció zavara (37.B ábra). 
A

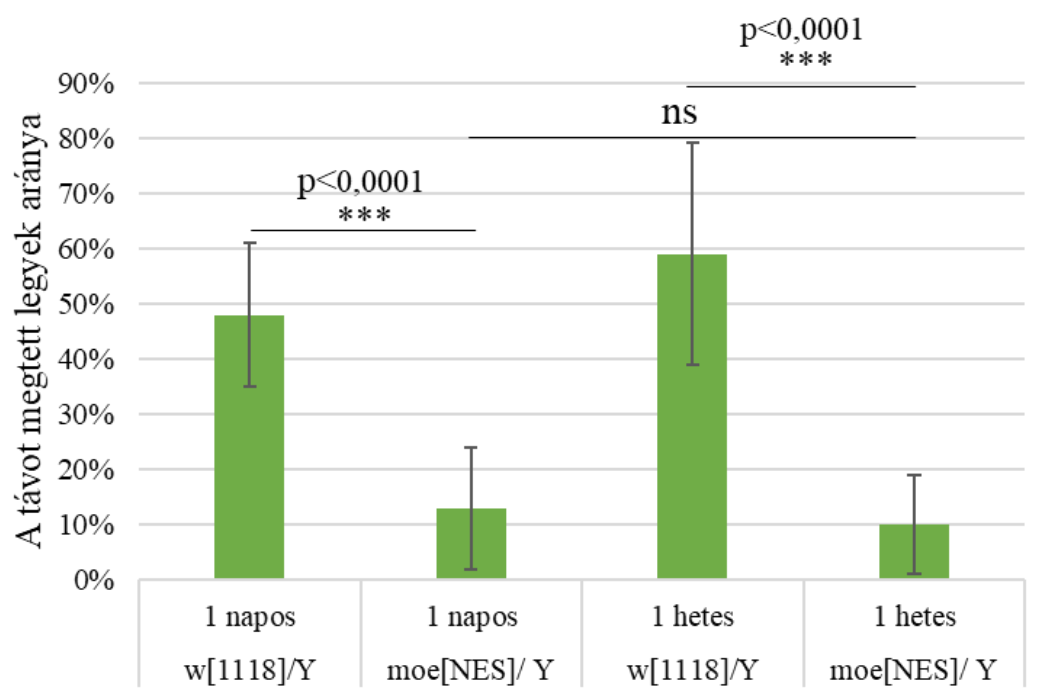

B

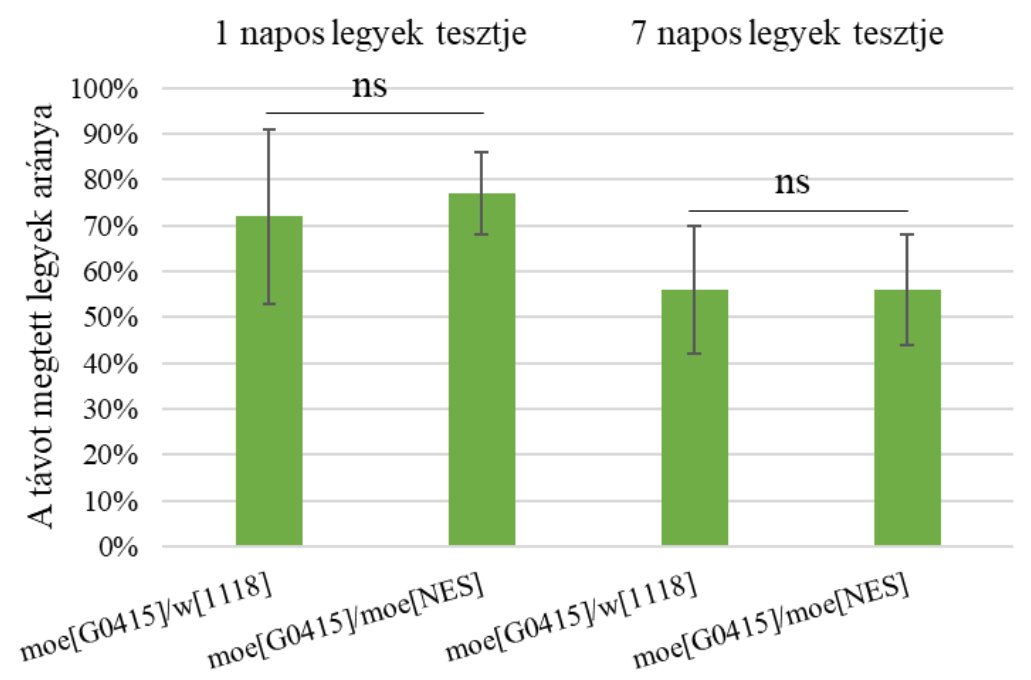

37. ábra A moe[NES] legyek motoros funkciójának vizsgálata. A hímek mászástesztje során (A) a moe[NES]/Y legyek lassabbak, mindössze 10\%-uk képes a mért távolságot (15 $\mathrm{cm}) 8$ másodperc alatt megtenni. A mutáns nőstények viszont hasonló eredményt értek el a mászásteszten (B), mint a vad típusú nőstények, így megállapítható, hogy a csökkent mászóképesség csak a moe[NES] hímeket érinti.

\subsubsection{A moe[NES] mutáns vonalak anyai hatású sterilitása}

Már a moe[NES] vonal létrehozása során azonnal, a kísérletek legelső fázisában nyilvánvalóvá vált a domináns anyai hatású sterilitás. Megfigyeltük, hogy a moe[NES] allélt akár egyetlen kópiában hordozó nőstények utódai valamennyien sterilek lettek, azaz a nőstények unokátlan (grandchild-less) fenotípusúak voltak. Munkánk további részében a sterilitás anatómiai és molekuláris okait vizsgáltuk. 


\section{A MoeNES fehérje citoplazmatikus funkcióinak vizsgálata}

A Moesin hiánya az élettel összeegyeztethetetlen, a null mutáns sejtek és állatok elpusztulnak. A moe[NES] homozigóta nőstények és hemizigóta hímek ugyanakkor életképeseknek bizonyultak, ami a MoeNES fehérje aktivációjának és citoplazmatikus funkcióinak legalább részleges épségét bizonyítja. Azonban a moe[NES] mutánsban a megfigyelt fenotípusok miatt mégis fennáll a lehetősége, hogy a Moesinnek nemcsak a sejtmagi funkciói hiányoznak, hanem a citoplazmás funkciói is részlegesen sérültek, s ez hozzájárul a megfigyelt elváltozásokhoz. Ezért a domináns anyai hatású sterilitás okainak mélyebb felderítését elöször annak tisztázásával kezdtük, hogy a MoeNES fehérje megfelelően ellátja-e a vadtípusú Moesin citoplazmatikus feladatait, illetve hogy a nukleáris export tag (NES) nem okoz-e mellékhatásokat. Ezeknek a vizsgálatoknak az eredménye természetesen nem csak a sterilitás, hanem a többi mutáns fenotípus szempontjából is fontos volt.

\section{A MoeNES fehérje aktivációja és lokalizációja}

Az ivarsejthiányos fenotípus megjelenésének egy másik lehetséges oka az lehet, hogy a NES szekvencia miatt a MoeNES fehérje nem képes megfelelően aktiválódni és ennek következtében funkcióját ellátni. Ezért elvégeztük a Moesin aktiválódását jelző, 559. pozícióban levő, foszforilált treoninra specifikus foszfo-ERM (P-ERM) ellenanyaggal a $m o e[\mathrm{NES}] /$ moe $^{\mathrm{G} 0415}$ petefészkek festését. Az immunfestés segítségével megállapítható volt, hogy a MoeNES fehérjét a P-ERM ellenanyag felismeri, azaz a fehérje megfelelően képes aktiválódni, sőt a vad típussal megegyező módon lokalizál a sejtkortexen (38. ábra), ami egyúttal az F-aktinkötő képességének épségére is utal. 


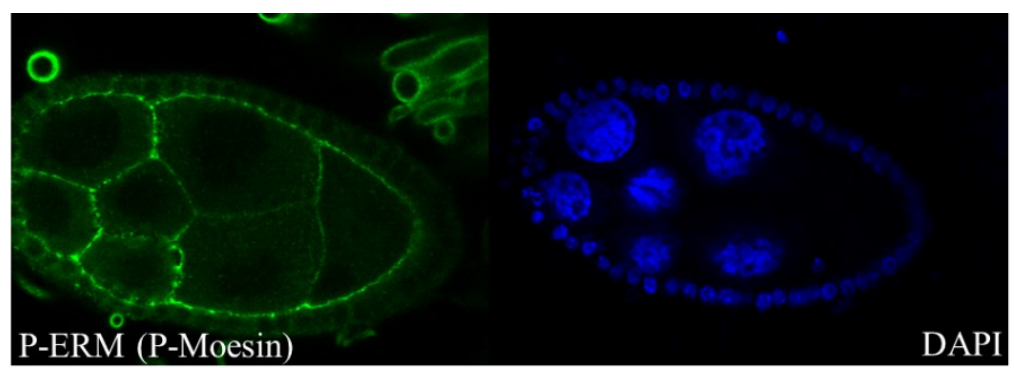

vad típus

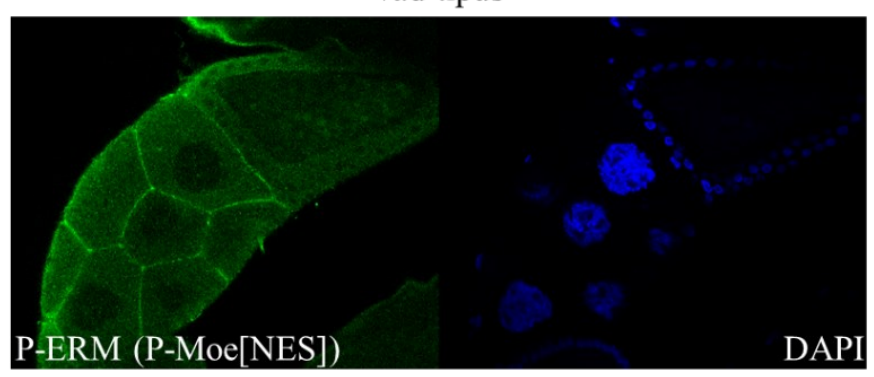

moe $[\mathrm{NES}] / \mathrm{moe}^{G 0415}$

\section{8. ábra MoeNES fehérje azonosítása foszfo-ERM (P-ERM) ellenanyaggal a petefészekben. A MoeNES fehérje a vad típusú fehérjével megegyező módon foszforilálódik és aktiválódik.}

\section{A CRM1 útvonal épsége}

A MoeNES fehérje sejtmagi exportja a NES szekvenciáját felismerő CRM1 (más néven embargoed vagy XPO1) export faktor segítségével valósul meg. A következőkben azt ellenőriztük, hogy a módosított Moesin fehérje esetleg befolyásolja-e, pl. túlterhelés révén gátolja a CRM1 export útvonal normális müködését, és esetleg legalább részben ez a mellékhatás okozza-e a tapasztalt fenotípusokat. Ehhez vad típusú és mutáns nőstények petefészkének dajkasejtjeiben megvizsgáltuk a CRM1 egy másik szállítmányának, a Medea (Med-GFP) fehérje mennyiségének arányát a sejtmagban és a citoplazmában. Az export túlterhelése esetén a Med-GFP magi halmozódása lenne megfigyelhető. A vad és mutáns dajkasejtek sejtmagjában azonban közel azonos arányban volt jelen a Med-GFP, szignifikáns eltérést nem tapasztaltunk, ami alapján elmondható, hogy a moe[NES] mutánsokban a CRM1 útvonal müködése normális (39. ábra). 


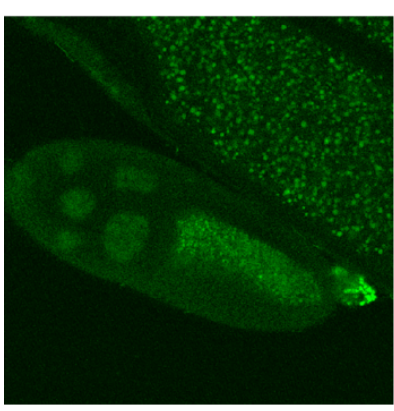

+/+;Med-GFP/+

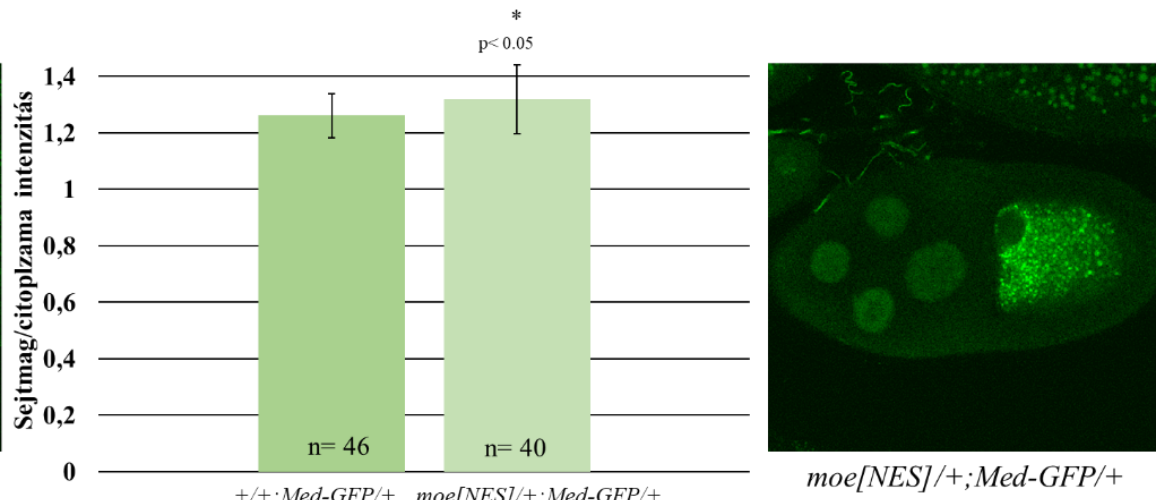

39. ábra CRM1 útvonal épségének ellenőrzése.

A Med-GFP (zöld szín) hasonló mennyiségben figyelhető meg a mutáns legyek petefészkeinek dajkasejtjeiben, mint a vad típus esetében, így elmondható, hogy a CRM1 útvonal megfelelően müködik a moe[NES] mutáns legyekben.

\subsubsection{Az anyai hatású sterilitás oka}

Az ivarszervek vizsgálata a moe[NES] anyák és nöstény utódaik petefészkeiben

A moe[NES] mutáció domináns módon, 100\%-ban sterilitást okoz a moe[NES] nőstények utódaiban, vagyis a MoeNES fehérje domináns anyai hatású faktorként gátolja az ivarsejtek kifejlődését, mely az úgynevezett grandchild-less (unokátlan) fenotípus kialakulását eredményezi. A jelenség kialakulásának okait felderítendő a következőkben először a moe[NES] anyák, valamint utódaik petefészkeit az ivarvonal őssejtekre, illetve az ivarsejtekre specifikus ellenanyagokkal festettük meg. A mikroszkópos képek alapján megállapítottuk, hogy a moe[NES] anyák petefészkeiben mind az ivarvonal őssejtek, mind az ivarsejtek megfelelően kialakulnak, jól azonosíthatók az ivarvonal őssejtekre specifikus HTS (Hu li tai shao) és az ivarsejteket jelölő Vasa fehérjéket felismerő ellenanyagokkal. Ugyanakkor a moe[NES] nőstények utódainak petefészkében nem találhatók sem ivarvonal őssejtek, sem ivarsejtek, sőt az utódok petefészke a normális struktúrát sem mutatja (40. ábra). 


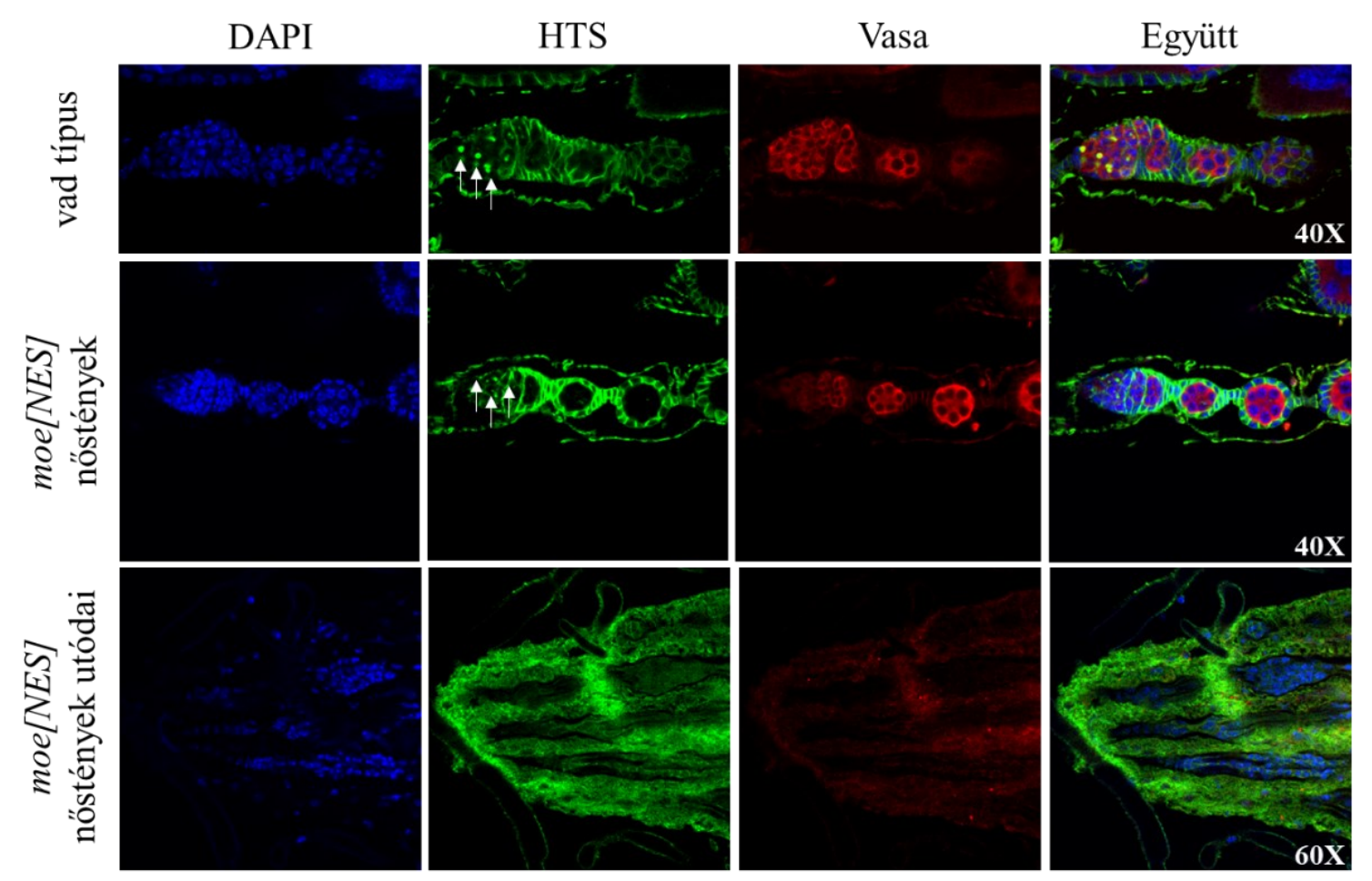

40. ábra A moe[NES] nőstények és utódaik petefészkén végzett HTS és Vasa festés. A moe[NES] nőstény utódok petefészkei kisméretűek és csökevényesek voltak. Az egyes ovariolákban a germárium sem felismerhető és teljesen hiányoznak az ivarvonal őssejtek (HTS), valamint az ivarsejtek (Vasa). HTS: ivarvonal őssejt specifikus ellenanyag, zöld színnel jelölve. Vasa: ivarsejt specifikus, pirossal jelölve. DAPI festés: kék.

\section{Az ivarsejtek vizsgálata a moe[NES] anyák embrióiban}

Mivel az ivarsejtek hiányoztak a nőstény utódok petefészkeiből és a petefészkek szerkezete is teljesen eltért a normálistól, a következő kísérletekben az utódok ivarvonal őssejtjeinek (GSC-k vagy poláris sejtek), illetve petefészkeinek fejlődését követtük nyomon az egyedfejlődés kezdeteitől, hogy megállapítsuk, mikor és hogyan történik az ivarsejtvesztés. Ehhez elöször a moe[NES]/+ anyák embrióinak fejlődése során tanulmányoztuk a poláris sejtek lefüződését, melyekből a fejlődés későbbi szakaszában az ivarsejtek alakulnak ki. A kísérletekben az embrió poszterior pólusán lefüződő ivarvonal őssejteket a Vasa fehérje segítségével tettük láthatóvá. A moe[NES]/+ nőstények 1 órás, fixált embrióin végzett immunfestése alapján kijelenthető, hogy az ivarvonal őssejtek a megfelelő időben és számban lefüződnek, alakjuk normális. A poláris sejtek lefüződésének folyamatát nyomon követő mikroszkópos filmeken ugyanakkor már az is jól láthatóvá vált, hogy ugyan a mutáns anyák petéiben a poláris sejtek időben és normális számban lefüződnek, ám nem sokkal később, a gasztruláció kezdeti szakaszában, a vad típussal ellentétben, elveszítik a Vasa-GFP szignált, eltünnek (41. ábra). 

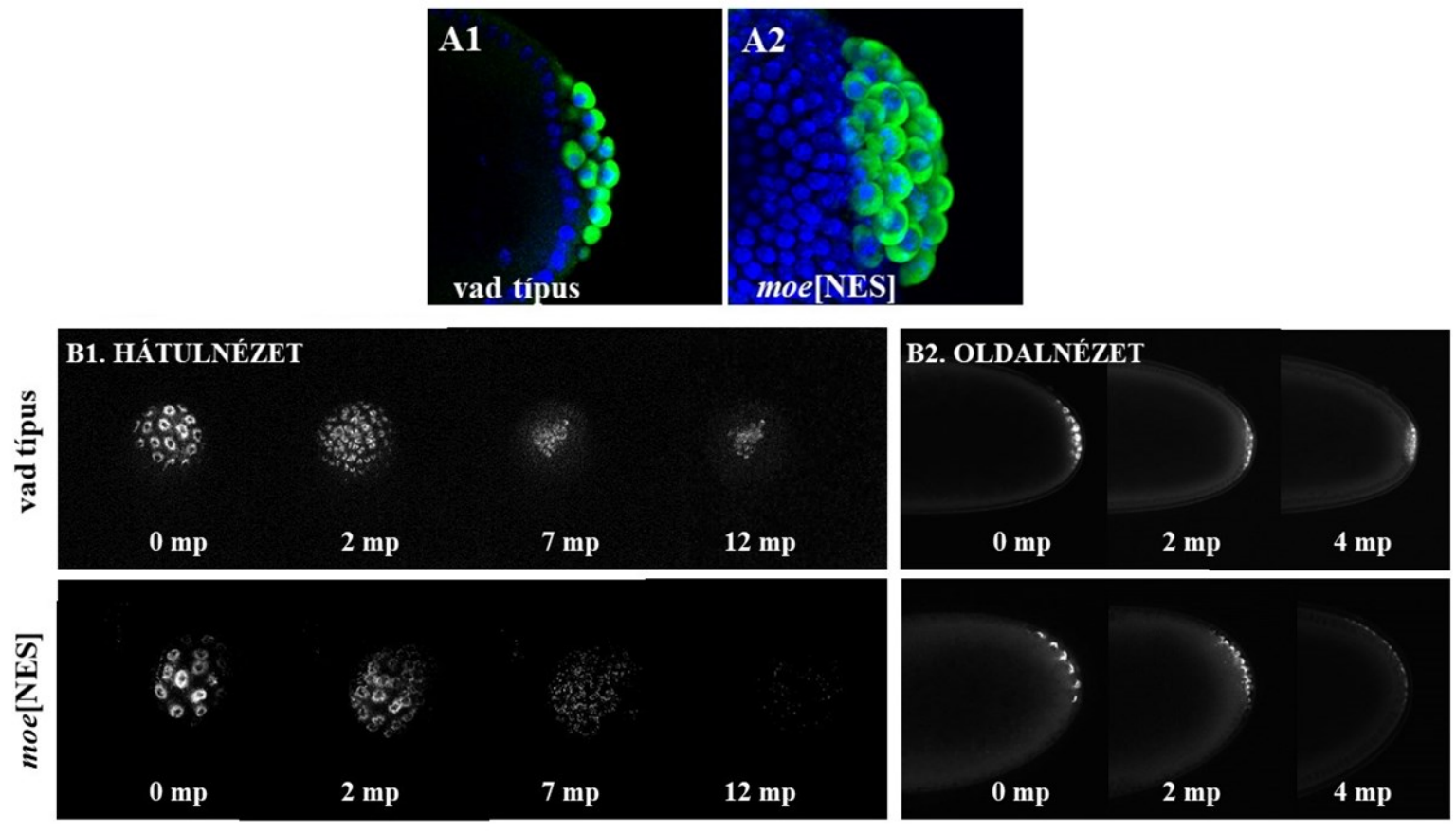

41. ábra A poláris sejtek lefüződésének folyamata.

A moe [NES]/+ nőstények embriói esetében az ivarsejtek lefüződnek (A2), majd a gasztruláció megindulásakor, a passzív vándorlásuk kezdetekor elvesztik a Vasa-GFP jelet (B1-B2). Az A1 és A2 képeken a Vasa zölddel, míg a B1 és B2 felvételeken fehér színnel van jelölve.

A korai embriókban végzett mikroszkópos vizsgálatokkal megállapítottuk, hogy a sterilitás hátterében a poláris sejtek elveszése áll, így a következőkben az ivarvonal őssejtek eltünésének lehetséges okait kerestük. Az elveszés eredménye lehet a korai apoptózis, az identitás elvesztése, a transzpozonok nem megfelelö szabályozása, illetve az anyai hatású faktorok nem megfelelő lokalizációja. Ennek megfelelően a moe[NES]/+ anyák petefészkein vizsgáltuk a transzpozonok szabályozásának épségét és a kulcsfontosságú anyai hatású faktorok lokalizációját. A mutáns anyák embrióin az apoptózist jelző, illetve az idő előtti transzkripciós aktivitás megindulásának kimutatására szolgáló kísérletek a dolgozat megírásakor folyamatban vannak.

\section{Transzpozon aktivitás vizsgálata a moe[NES] nöstények petefészkeiben}

A moe[NES] mutánsokban megfigyelt sterilitás egyik lehetséges oka a transzpozonok aktiválódása a petefészekben. Normál állapotban a transzpozon elleni védekezés az ivarvonal sejtekben az úgynevezett Piwi RNS-eken keresztül valósul meg, így csökkentve a transzpozonok mozgásából adódó mutációs gyakoriságot (Jankovics és mtsai, 2018). Ennek megfelelően megvizsgáltuk a moe[NES] mutáns nőstények ivarvonalában a transzpozonok szabályozását. A transzpozonok aktivitását érzékelő HetA és Burdock 
szenzorokat is kifejező moe[NES] mutáns nőstények petefészkein $\beta$-Gal festést végeztünk, pozitív kontrollként az UAS $>$ sov-RNSi[3-2]; nos $>$ Gal4 törzset használtuk, melynek ivarvonal sejtjeiben bizonyítottan magas a transzpozonok aktivitása (Jankovics és mtsai, 2018). A mikroszkópos felvételek alapján egyértelmüen megállapítható volt, hogy a pozitív kontrollal ellentétben a moe[NES] mutánsban nem detektálható transzpozon aktivitás, tehát a Moesin mutánsokban megfigyelt ivarsejt elveszésért nem a transzpozonok aktivizálódása a felelős (42. ábra).
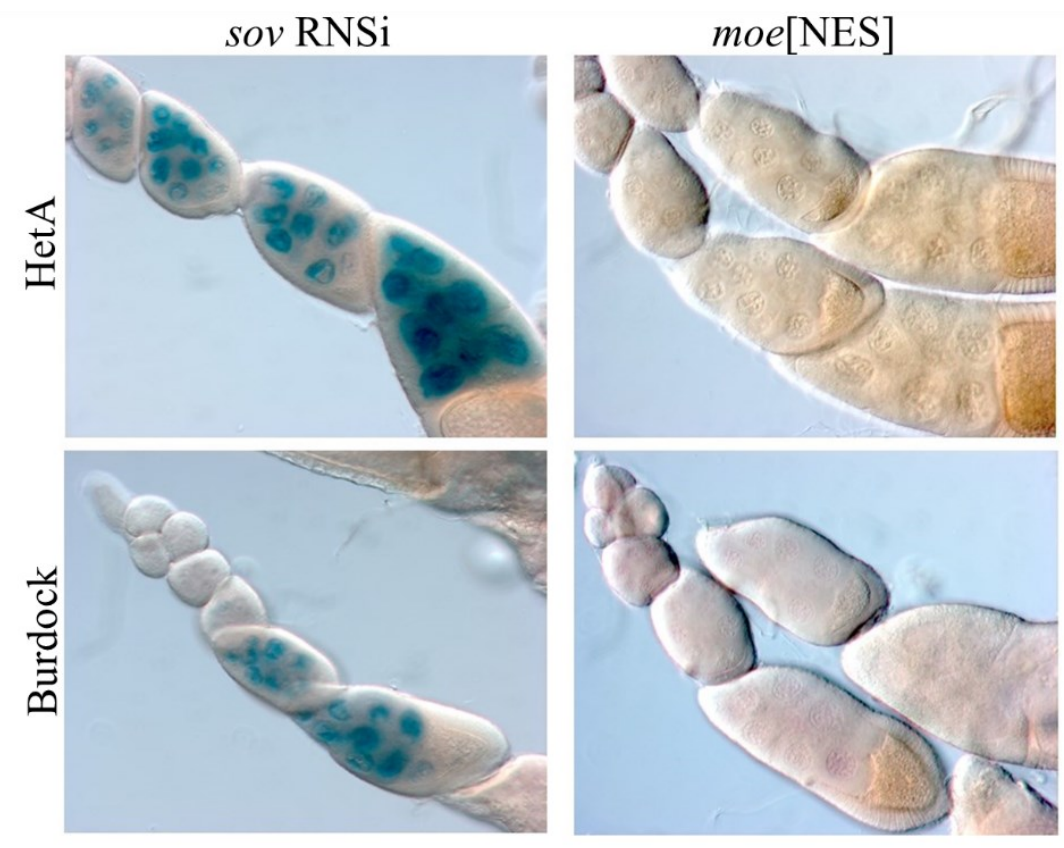

42. ábra A transzpozonok aktivitásának vizsgálata a moe[NES] mutáns nőstények petefészkeiben.

A moe[NES] mutáns legyek esetében nem figyelhető meg a transzpozonok túlmüködése. A transzpozonok aktivitását $\beta$-Gal festésnél kék színü csapadék jelzi a dajkasejtek magjában. A HetA és Burdock a kísérletben használt transzpozon szenzorok, míg pozitív kontrollként a sov gén RNSi csendesítése szolgált.

Az anyai hatású faktorok vizsgálata a moe[NES] anyák ováriumában

A poláris sejtek megfelelő fejlődéséhez anyai hatású faktorok, mint például az oskar mRNS és Vasa fehérje megfelelő mennyisége és a fejlődő embriók poszterior pólusán félkör alakban való koncentrált elhelyezkedése is elengedhetetlen (44.A ábra). A továbbiakban ezeknek a faktoroknak az eloszlását, illetve mennyiségét vizsgáltuk meg a moe[NES] nőstények petesejtjeiben és embrióiban. Az oskar mRNS lokalizációjáról megállapítottuk, hogy a moe[NES] (moe[NES]/moe $e^{\mathrm{G} 0415}$; oskar-MS,MS2-GFP/TM3) nőstények 10. fejlődési 
stádiumban lévő petesejtjeiben az oskar mRNS minden vizsgált esetben a vad típushoz hasonlóan a poszterior póluson helyezkedik el.

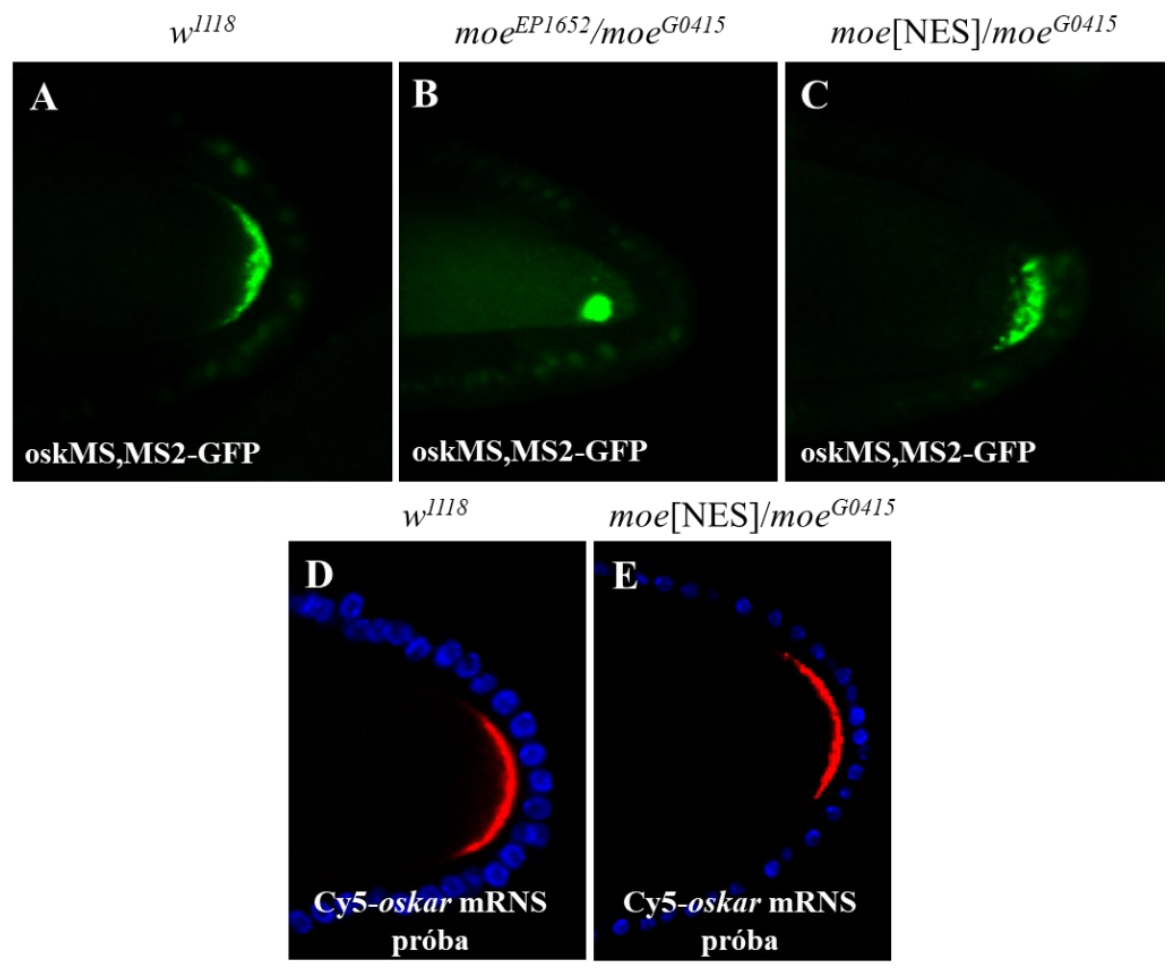

43. ábra oskar-MS,MS2-GFP lokalizációja moe[NES] mutáns nőstények embrióiban.

A moe[NES] nőstények embrióiban az oskar mRNS lokalizáció megfelelö, a pozitív kontrollként használt $m o e^{E P 1652} /$ moe $^{\mathrm{G} 0415}$ nőtények embrióihoz hasonló hibás oskar mRNS lokalizációt (B) nem figyeltünk meg a moe[NES] anyák utódaiban (C). A mutáns nőstényekben az endogén oskar mRNS lokalizációja (E) teljesen megegyezik a vad típusú nőstényekben megfigyelt elrendeződéssel (D).

Ugyanakkor a kísérletben pozitív kontrollnak használt moesin hipomorf és null mutáns allélját hordozó (moe $e^{E P 1652} /$ ooe $^{\mathrm{G} 0415} ;$ oskar-MS,MS2-GFP/TM3) nőstények petesejtjeiből 14,8 \% mutatott a poszterior pólustól távol eső oskar mRNS lokalizációt (43.B ábra), illetve a vizsgált petesejtek 7,4\%-ban egyáltalán nem detektáltunk oskar mRNS-t a poszterior póluson. Tehát a pozitív kontrollként használt moesin mutáns petesejtek mintegy negyede $(23,2 \%)$ mutatott oskar lokalizációs problémát, szemben a moe[NES] mutánssal, ahol nem figyeltünk meg ilyen fenotípust (43.C ábra). A moesin funkcióvesztéses allélkombinációja $\left(m o e^{E P 1652} /\right.$ ooe $\left.^{\mathrm{G} 0415}\right)$ esetén a Moesin citoplazmatikus funkciója bizonyítottan sérül (Jankovics és mtsai, 2002). A normális oskar mRNS lokalizáció alapfeltétele a megfelelően szerveződött citoszkeletális hálózat, mely a $m o e^{E P 1652} / m_{0} e^{\mathrm{G} 0415}$ nőstények utódainak esetében nem áll fenn, ezért detektálható a normálistól eltérő oskar mRNS elrendeződés ezekben a petesejtekben. Az oskar mRNS lokalizációs vizsgálataiból 
megállapítható tehát, hogy a moe[NES] mutáns vonalak esetében a megfigyelt sterilitás nem az oskar transzkript abnormális elhelyezkedéséből adódik (43.D-E ábra).

A moe [NES] mutánsok anyai hatású domináns sterilitásának analízisét a Vasa fehérje eloszlásának vizsgálatával folytattuk a moe[NES]/+; vasa-AIDGFP/+ nőstények 1 órás fejlődő embrióiban (44. ábra). Az embriók anterior-poszterior tengelye mentén mért GFP intenzitási értékeket grafikonon ábrázolva meghatároztuk a mutáns

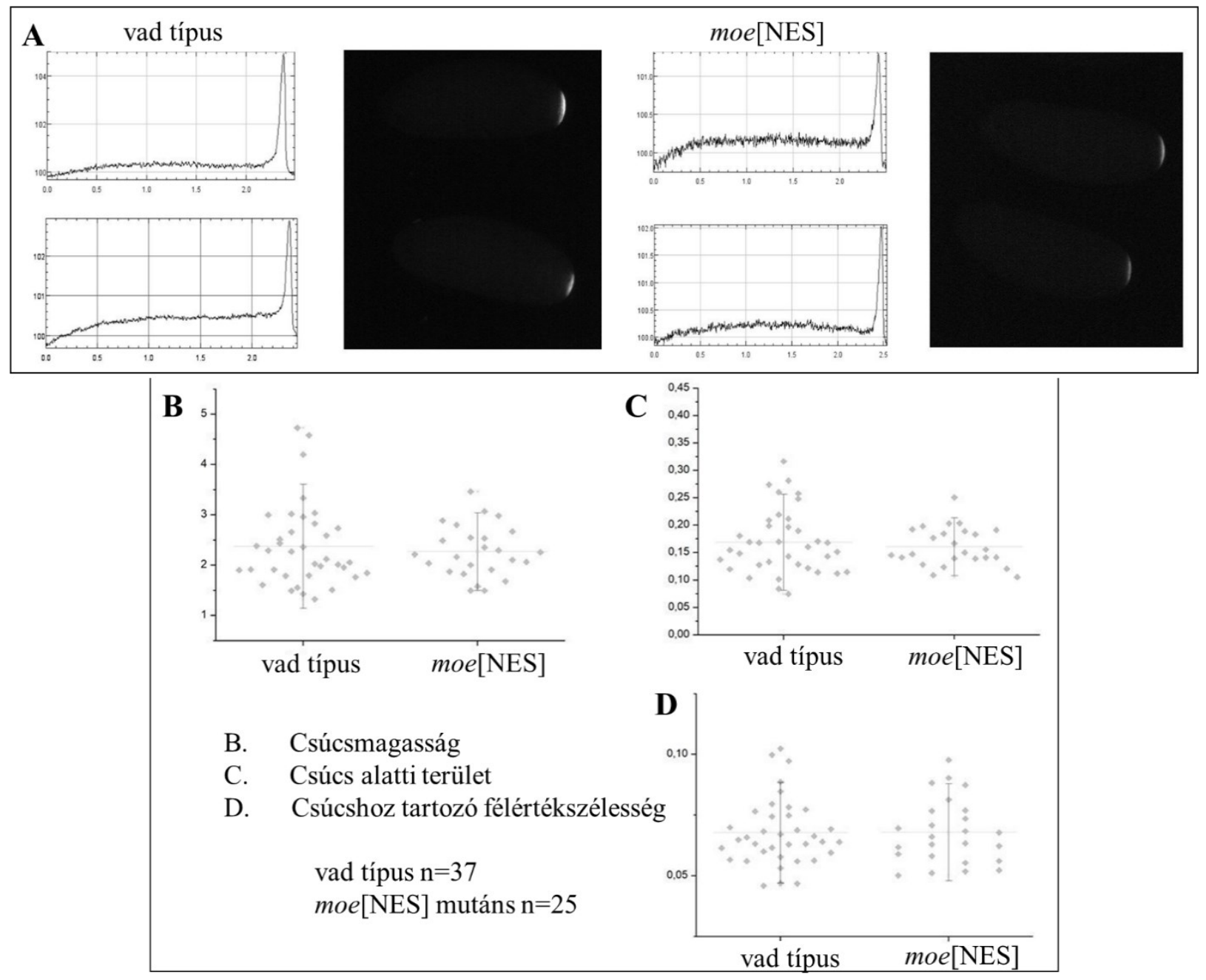

44. ábra A Vasa fehérje mennyiségének és eloszlásának vizsgálata a moe[NES] anyák embrióiban fluoreszcens mikroszkóppal. A vad és moe[NES] embriók hosszában felvett intenzitás értékekből határoztuk meg a Vasa-GFP eloszlását (A). A mutáns embriókban a

Vasa-GFP eloszlása (B) és mennyisége (C) megegyezik a vad típusú embriókban mért értékekkel. Továbbá az is megállapítható, hogy a mutáns embriókban a Vasa-GFP fehérje hasonló módon oszlik el (D), mint a kontroll embriókban.

embriókban a Vasa-GFP eloszlását (csúcs alatti terület), mennyiségét (csúcsmagasság), és elhelyezkedését (csúcshoz tartozó félérték szélesség). A kiértékelt adatok azt mutatták, hogy 
a moe[NES] nőstények embrióiban a Vasa-GFP hasonló mennyiségben, elhelyezkedésben és eloszlásban van jelen mint a kontrollként használt vasa-AID-GFP/+ anyák embrióiban. Így a lokalizációs vizsgálatok alapján elmondható, hogy a moe[NES] vonalakban megjelenő sterilitásért nem a korai embriogenezisben részt vevő anyai hatású faktorok rendellenes lokalizációja a felelős.

Ugyanakkor azonban nem zárható ki a dajkasejtek által termelt anyai hatású transzkriptek összmennyiségében bekövetkező változás, mely a Moesinnek a transzkripcióban és mRNS exportban betöltött szerepéből következhet. Ezért a későbbi kísérleteink során megvizsgáltuk az egyes anyai hatású faktorok relatív transzkriptmennyiségét is, valamint teljes RNS szekvenálás alkalmazásával jellemeztük a transzkripció állapotát a moe[NES] anyák petefészkében.

\subsubsection{A transzkripció vizsgálata a moe[NES] anyák ováriumában}

A laboratóriumunkban végzett korábbi munkák során megállapítottuk, hogy a Moesin részt vesz a sejtmagi mRNP komplexek szállításában, ami miatt a moesin RNS interferencia hatására mRNS halmozódás figyelhető meg a nyálmirigyek sejtmagjaiban (Kristó és mtsai, 2017). Ezért egy fluoreszcens próba segítségével megvizsgáltuk a moe[NES] hemizigóta hím lárvák nyálmirigyeiben az mRNS-ek eloszlását, valamint teljes mRNS szekvenálással tanulmányoztuk, hogy az egyes gének esetében hogyan változnak a relatív transzkriptmennyiségek a moe[NES]/moe $e^{\mathrm{G} 0415}$ nőstények petefészkeiben.

A moe[NES] hemizigóta hím lárvák nyálmirigyeinek sejtmagjában egyértelmü mRNS halmozódást detektáltunk (45. ábra), ami a magi mRNS export sérülését jelzi. Kontrollként a moe[NES] törzsből származó, kapcsolt X kromoszómákat hordozó nőstények nyálmirigyeit használtuk párhuzamosan, ahol a vártnak megfelelően nem detektáltunk mRNS halmozódást a sejtmagokban. 

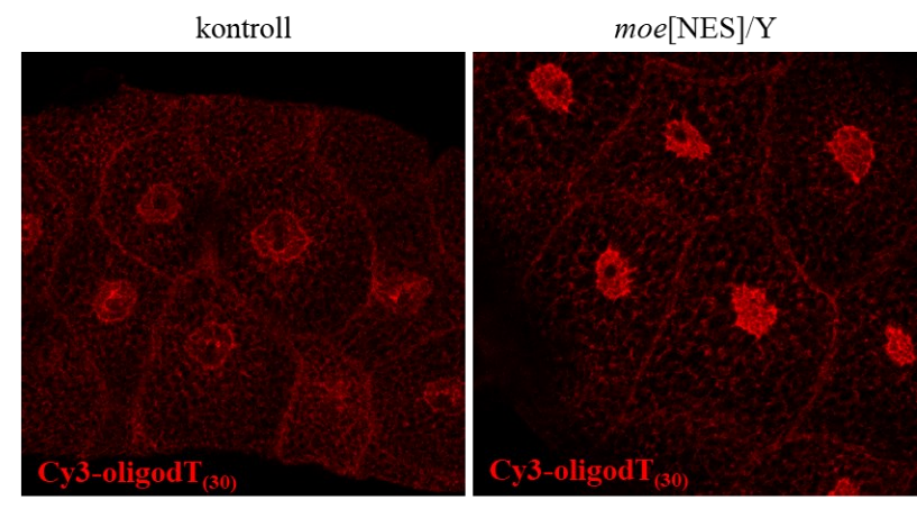

\section{5. ábra A moe[NES]/Y hímek nyálmirigyeinek sejtmagjaiban mRNS halmozódást (piros szín) figyeltünk meg, ami a sejtmagi mRNS export hibájára utal. Kontrollként a kapcsolt X kromoszómákat hordozó nőstényeket használtuk.}

A teljes mRNS szekvenálás során 10 darab, 3 napos moe[NES] $/$ moe $^{\mathrm{G} 0415}$ mutáns nőstény mellett kontrollként $w^{1118} / m_{0} e^{\mathrm{G} 0415}$, valamint a domináns hatás kontrollálására $m o e[\mathrm{NES}] / w^{1118}$ nőstények petefészkeit használtuk. A szekvenálás során minden genotípusból három párhuzamos biológiai minta feldolgozása történt meg. A fökomponensanalízis (Principal Component Analysis - PCA) során a biológiai minták között fennálló hasonlóságot ábrázoltuk, mely alapján megállapítható, hogy a genotípusonként használt három független mintából a 2. ismétlés minden értéke jelentős eltérést mutat a többi értéktől (46. ábra), így az adatok analízisét ezen minták kihagyásával végeztük el.

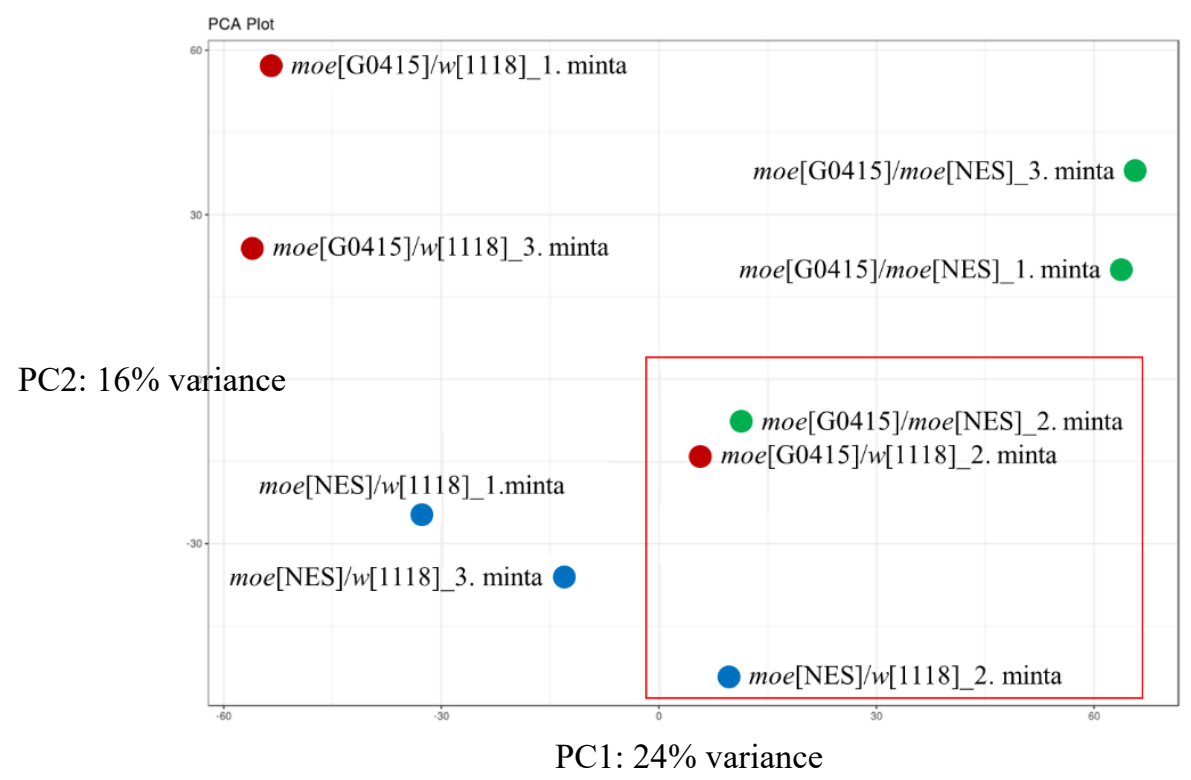


46. ábra A teljes mRNS szekvenáláshoz használt minták fökomponens-analízise. Az analízis során megállapítható, hogy a 2. minták értékei (piros négyzettel körülhatárolva) eltérnek, így a teljes mRNS szekvenálás kiértékelését ezek kihagyásával végeztük el. A piros a moe[G0415]/w[1118], a zöld a moe[G0415]/moe[NES], míg a kék pontok a $m o e[\mathrm{NES}] / \mathrm{w}[1118]$ genotípusú legyekből származó mintákat jelölik.

Az analízis során 17055 gént tudtunk azonosítani, melyből 371 esetben detektáltunk a vad típusú kontrollnál szignifikánsan magasabb, illetve 315 gén esetében alacsonyabb transzkriptmennyiséget. Ezen felül 386 gén esetében az expressziós mintázat domináns változását mutattuk ki. Ez utóbbi esetekben már egyetlen moe[NES] allél a moe[NES] $/$ moe $^{\mathrm{G} 0415}$ mutánsban mért transzkriptszinthez hasonló változást okozott, melyet a vad típusú allél nem volt képes menekíteni.

A gének biológiai funkciók szerinti csoportosítását többféle, erre a célra fejlesztett szoftver (GOrilla, ShinyGO) segítségével is elvégeztük. Azonban a kapott eredményeket átfedőnek és olykor nehezen értelmezhetőnek találtuk, mivel az alkalmazott online programok nem vették figyelembe a Gene Ontology (GO) term génjelölések hierarchikus felépítését. Ezért manuálisan, a Flybase (https://flybase.org) GO terms adatbázisa alapján, valamint a Ghenti Egyetemen Yves Van de Peer bioinformatikai laboratóriuma által fejlesztett „Venn Diagrams” nevü (bioinformatics.psb.ugent.be/webtools/Venn/) online program segítségével is elvégeztük az analízist. Az elemzés során a kontrollhoz képest magasabb és alacsonyabb expressziót mutató gének csoportosításával három olyan biológiai funkciót sikerült azonosítanunk, melyek köré a legtöbb, transzkriptszint csökkenést vagy növekedést mutató gént sikerült besorolnunk. Az így kialakított csoportok a következők voltak: egyedfejlödés, környezeti hatásokra adott válaszreakciók és a transzkripció. Az analízis során olyan biológiai funkciókon alapuló csoportokat is kialakítottunk, melyek egyediek. A transzkriptszint csökkenést mutató gének esetében ilyenek a sejtciklus és a kromoszómaszerveződés, míg a magasabb expressziós szinttel azonosított géneknél a fehérje metabolikus folyamatok (47. ábra). 

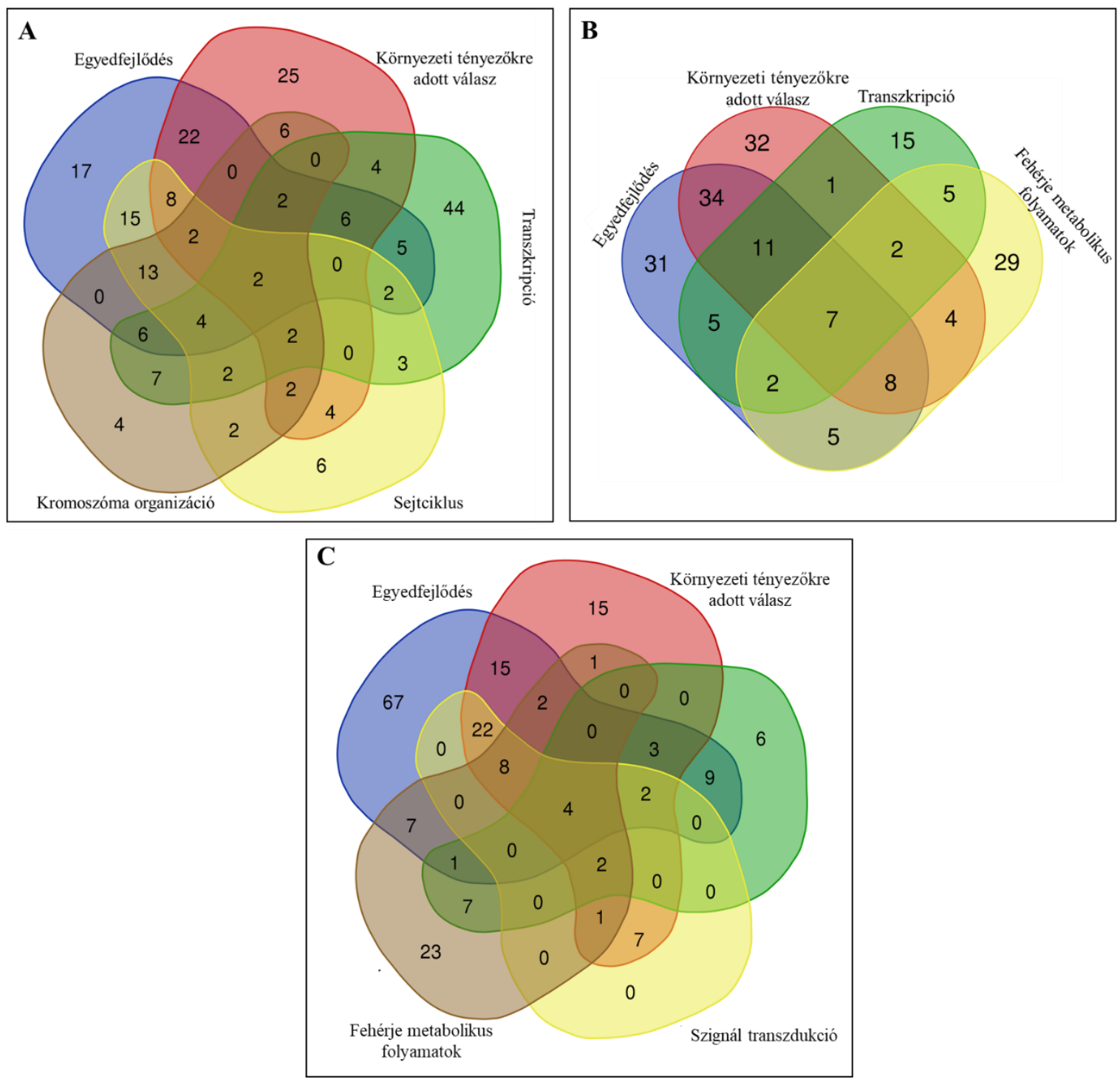

47. ábra A transzkriptszintben csökkenést (A), növekedést (B), valamint domináns módon megváltozott expressziós szintet $(\mathrm{C})$ mutató gének biológiai funkciók alapján történő csoportosítása. A transzkriptum mennyiségének csökkenését mutató gének 68,3 \%-a sorolható be az ábrán feltüntetett öt csoport valamelyikébe, míg a növekedést mutató gének 51,5\%-át tartalmazza a négy csoport összesen. A domináns hatás módon megváltozott expresssziójú $386 \mathrm{db}$ gén 52,3 \%-a tartozik az ábrán jelölt négy csoportba együttvéve.

A megfigyelt fenotípusok kialakulásában vesznek részt azok a gének is, melyeknek a megváltozott transzkriptszintjei a MoeNES fehérje domináns hatásához köthetők. Ennek a 386 génnek a besorolásakor öt nagyobb csoportot alakítottunk ki, melyek jelentősen átfednek (46. ábra). Legnagyobb kategóriát az egyedfejlődésben szerepet játszó gének alkotják (140 db), melyek nagy száma magyarázhatja a domináns módon kialakuló sterilitást, valamint a megfigyelt fejlődési rendellenességeket. Az ivarvonal őssejtek 

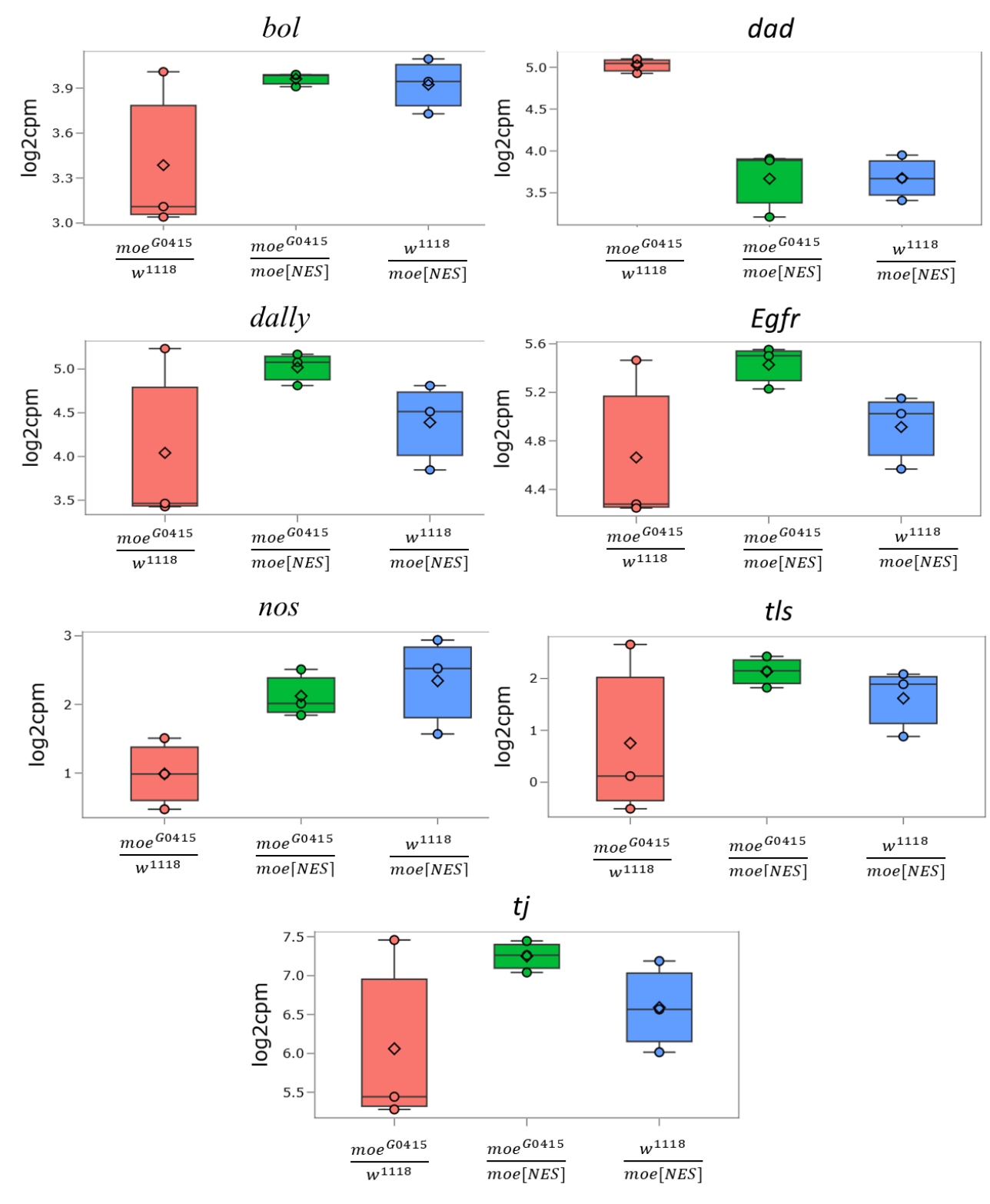

48. ábra Domináns módon megváltozott expressziós szintek.

A Moe[NES] domináns negatív hatása következtében összesen 386 gén esetében detektáltunk transzkriptmennyiség növekedést vagy csökkenést, melyeket a vad típusú moesin allél nem képes menekíteni.

fejlődésében szerepet játszó egyes gének esetében megfigyelhető, hogy a vad típusú allél nem képes enyhíteni vagy menekíteni a moe[NES] okozta fenotípust. Ezekben az esetekben arra következtethetünk, hogy a MoeNES fehérje domináns negatív módon felelős az adott gén kifejeződésében tapasztalható különbségért. Feltételezhetően a MoeNES fehérjének ez a hatása felelös a bol (boule), dad (Daughters against dpp), dally (division abnormally delayed), Egfr (Epidermal growth factor receptor), nos (nanos), tsl (torso-like), valamint a tj (traffic jam) esetében tapasztalt transzkriptszint különbségek kialakításában (48. ábra). 
Mivel feltételeztük, hogy a poszterior fejlődési rendellenességek megjelenésének oka az anyai hatású faktorok mRNS-ének mennyiségében bekövetkező változás, ezért megvizsgáltuk a mutáns nőstényekben az ismert anyai hatású faktorok (oskar, bicoid, staufen, gurken, $\left.f_{S}(1) K 10\right)$ transzkriptjeinek mennyiségét is. A vizsgált faktorok esetében azonban nem találtunk különbséget az expressziós szintekben a mutáns és a vad típusú kontroll között. Ezzel szemben a vasa transzkriptszintjében kismértékü emelkedést detektáltunk, továbbá megállapítottuk, hogy a decapentaplegic (dpp) útvonalban kulcsszerepet játszó dpp és a Notch faktorok génjeinek szignifikánsan megemelkedik a transzkriptszintje a moe[NES] mutáns nőstényekben (49. ábra).
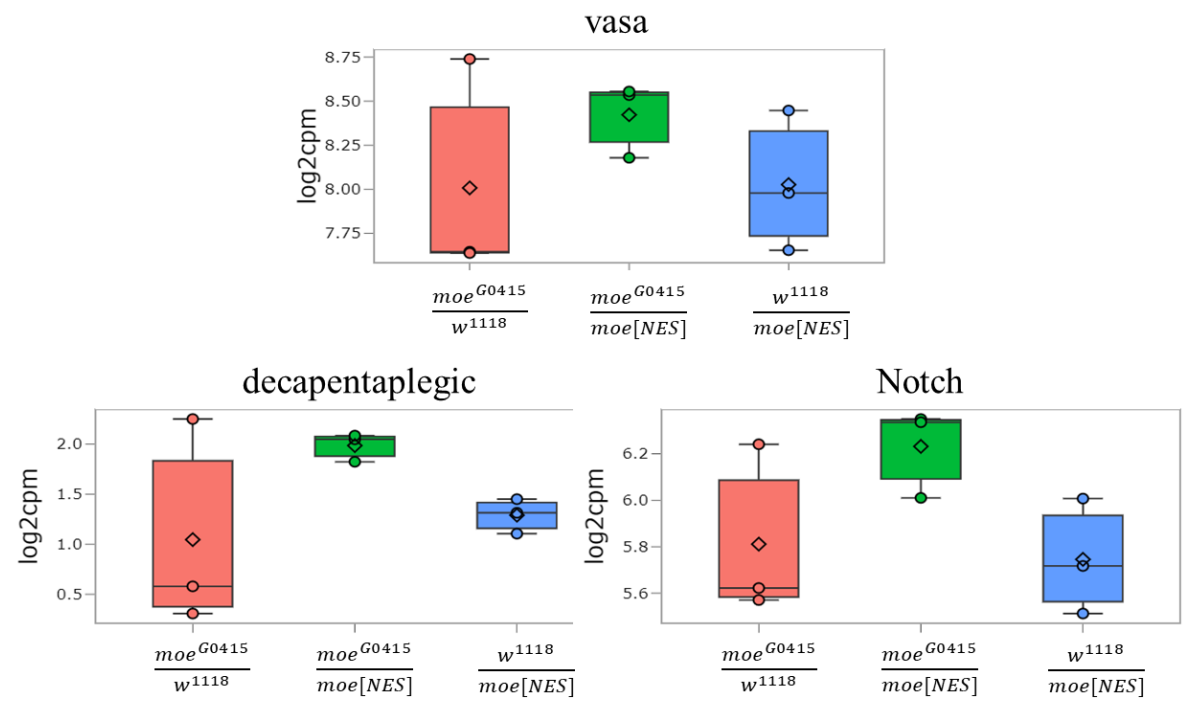

49. ábra A vasa, dpp, valamint a notch gének transzkripciós szintjei.

A mutáns legyek esetében a három gén transzkriptszintjének emelkedését tapasztaltuk a kontrollokban mért értékekhez képest.

A dpp kulcsszereplöje az egyik legfontosabb jelátviteli útvonalnak az ivarvonal őssejtek megfelelő fejlődésében, zavara esetén az ivarsejtek nem megfelelően differenciálódnak (Dansereau és mtsai, 2008). A Notch útvonal a sejtek differenciálódásában, valamint az őssejtek fenntartásában vesz részt, hiányában jelentősen csökken az ivarvonal őssejtek mennyisége (Xu és mtsai, 2012). A teljes mRNS szekvenálás adatai alapján valószínü, hogy a Moesin sejtmagi hiányából adódóan a mutáns nőstényekben a dpp, illetve a Notch mRNS-ek sejtmagi exportja gátolt, ami miatt az expressziójuk abnormálisan megemelkedik, így az általuk vezényelt útvonalak nem megfelelően müködnek, mely legalább részben hozzájárulhat a domináns sterilitás kialakulásához. A jövőben további kísérletek lesznek szükségesek ennek igazolására. 
Az anyai hatású gének, valamint az ivarvonal őssejtek fenntartásában szerepet játszó jelátviteli útvonalak résztvevői mellett részletesen megvizsgáltuk a mászóképességben szerepet játszó gének expressziós szintjét is, mivel feltételeztük, hogy a moe[NES] mutánsokban megfigyelt csökkent mászási képesség is összefügghet génexpressziós
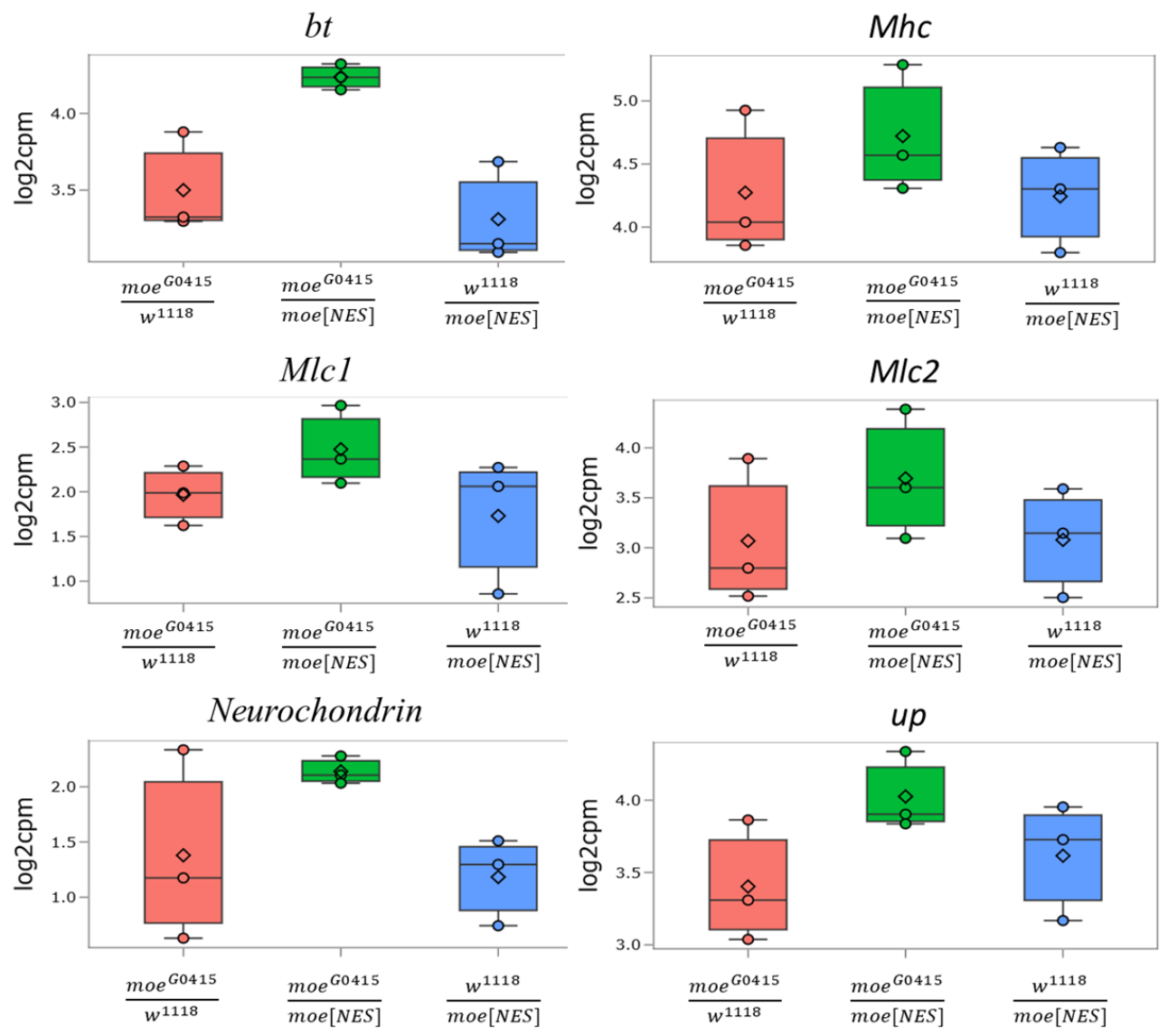

50. ábra A csökkent mászóképesség kialakításában vélhetően szerepet játszó gének.

A Flybase adatbázis alapján a $b t, M h c, M l c 1, M l c 2$, Neurochondrin, valamint az up génekhez kapcsoltak mozgásszervrendszerben megjelenő fenotípusokat.

változásokkal. Így olyan gének aktivitásának emelkedését detektáltuk, melyek a megfelelő izommüködés kialakításában fontosak, mint például a bt (bent), Mhc (Myosin heavy chain), Mlc1 (Myosin alkali light chain 1), Mlc2 (Myosin light chain 2), Neurochondrin, up (upheld) (50. ábra). Ezen gének megváltozott transzkripciós aktivitása okozhatja a csökkent mászóképességet a mutáns legyek esetében oly módon, hogy a Moesin sejtmagi hiánya az mRNS-eik sejtmagi exportjának sérülése révén az említett gének transzkripciós szintjének emelkedését eredményezi. 
Mindezeken túl, a teljes mRNS szekvenálás során kapott adatokból megállapítható volt az is, hogy hat hősokk gén (hsp70Aa, hsp70Ab, hsp70Ba, hsp68, hsp26, hsp23) kifejeződése szignifikánsan csökkent a mutáns legyek esetében (51. ábra). A jelenség
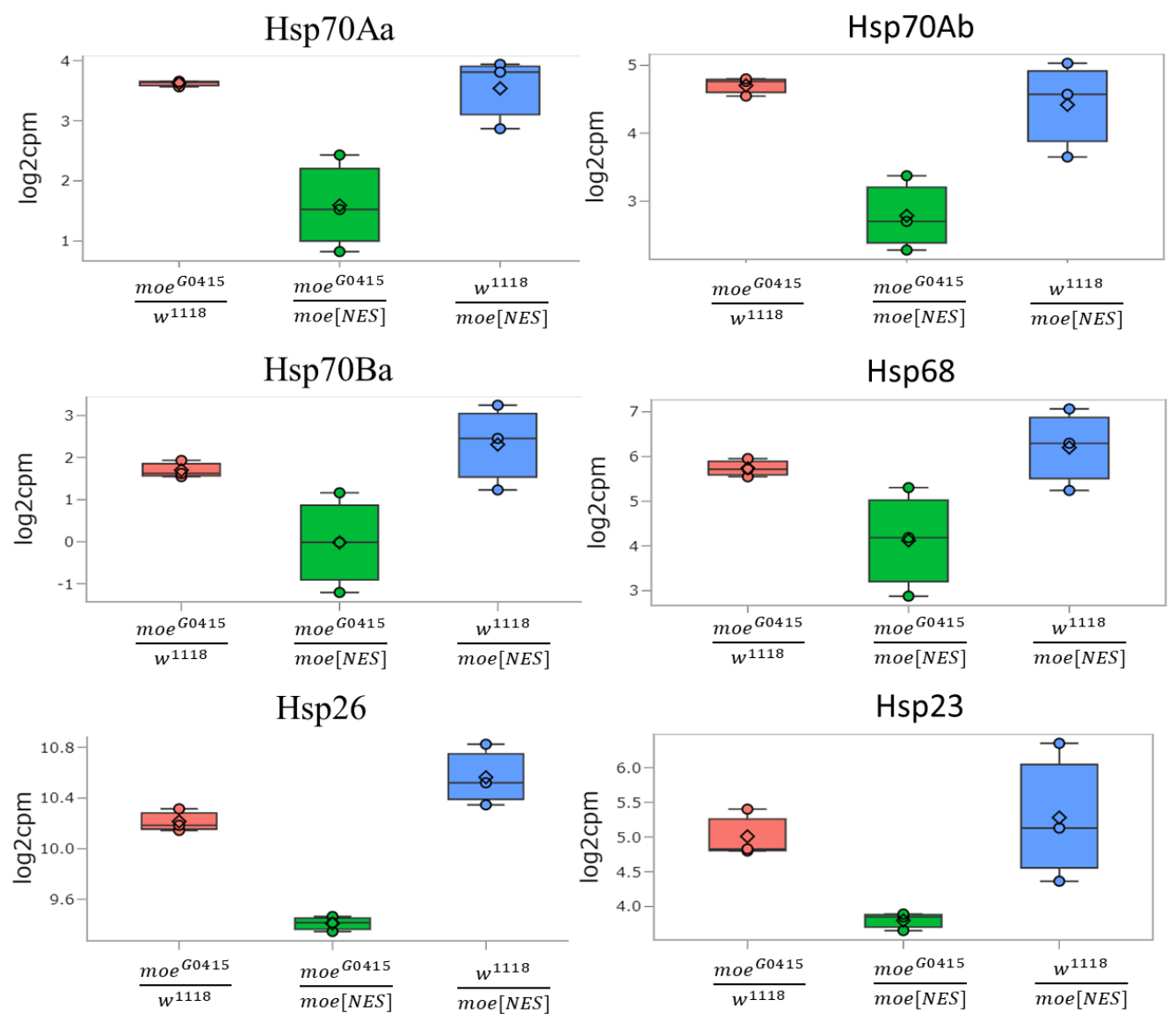

51. ábra A hsp gének transzkripciós szintjei a vizsgált nőstények petefészkeiben. A moe[NES] mutáns legyek esetében (moe $e^{\mathrm{G} 0415} /$ moe [NES]) csökkent $h s p$ mRNS szinteket detektáltunk a kontroll legyekhez képest.

recesszív jellegü, azaz egyetlen kópia vad típusú moesin allél menekíti az expressziós változást, úgy ahogy azt a fenotípus kapcsán az élettani kísérletekben is tapasztaltuk. Mindezek alapján elmondható, hogy a $h s p$ gének megfelelő átírásához nagy valószínűséggel a Moesin sejtmagi jelenléte szükséges, hiányában a hősokk gének kifejeződése gátolt.

\subsubsection{A sejtmagi Moesin szükséges a hösokk gének normális müködéséhez}

A hsp gének szabályos müködése Drosophila esetében szükséges a normális élethossz eléréséhez (Vos és mtsai, 2016), a fertilitáshoz és az ivarsejtek megmaradásához (Zimmerman és mtsai, 1983; Cobreros és mtsai, 2008), az ép mozgási aktivitáshoz (Xiao és 
mtsai, 2007; Kjaersgaard és mtsai, 2010), valamint a fejlődés normális üteméhez (Gong és mtsai, 2006). Mivel ezek a folyamatok mind sérültek a moe[NES] állatokban, a következő kísérletekben a csökkent $h s p$ génműködés részletes vizsgálatát végeztük el a mutánsokban.

A hősokk gének hibás müködésének leginkább kézzelfogható jele az állatok hőtürési képességének csökkenése, ezért először megvizsgáltuk, hogyan alakul a moe[NES] mutánsok életképessége höstressz hatására. A hímek rövidült élethosszt mutattak $25^{\circ} \mathrm{C}$-on, míg a nőstényeknek élethossza normális volt. Ezzel szemben az alkalmazott $29{ }^{\circ} \mathrm{C}$-on a moe[NES] hímek mellett már a mutáns nőstények is egyértelmü élethossz csökkenést mutattak (52. ábra), ami arra utal, hogy a moe[NES] mutáció a hőstressz türés csökkenését is okozza. Ez a csökkent hőtürés azonban egy kópia vad típusú moesin génnel menekíthető: az 52. ábrán jól látható, hogy a moe[NES] $/ w^{1118}$ életképessége a kontrollhoz $\left(m o e^{\mathrm{G} 0415 / w^{1118}}\right)$ hasonló.

Annak egyértelmü eldöntésére, hogy a megfigyelt rövidebb élethossz valóban a hőstressz miatt van-e, a kísérletet elvégeztük $18{ }^{\circ} \mathrm{C}$-on is (52. ábra). Az eredmény alapján megállapítottuk, hogy nőstények élethosszát ez a hőmérséklet nem befolyásolja, míg a moe[NES] hímek ezen a hőmérsékleten is rövidebb élethosszt mutatnak. Úgy gondoljuk, hogy ez a gyengébb életképesség a hímek esetében nem a csökkent hidegtürés következménye, hanem a moe[NES] hímek általános, $25^{\circ} \mathrm{C}$-on is megfigyelt élethossz csökkenésére vezethető vissza (52. ábra).

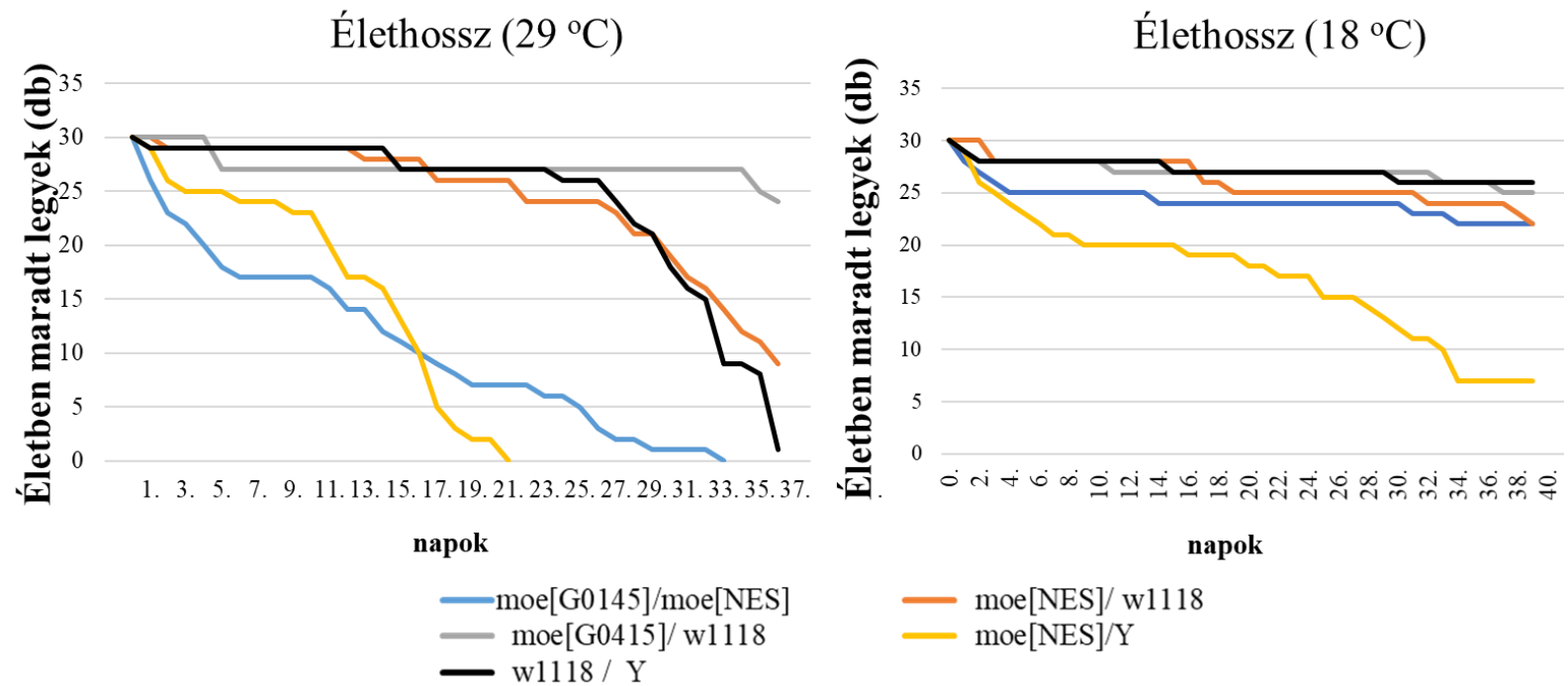

52. ábra A moe[NES] legyek hőstressz türésének jellemzése.

A $29{ }^{\circ} \mathrm{C}$-on végzett élethossz vizsgálat alapján megállapítható, hogy a hímek és nőstények egyaránt csökkent életképességet mutatnak, mely a Moesin sejtmagi hiányából adódó hőérzékenységböl adódik. A $18{ }^{\circ} \mathrm{C}$-on kapott eredmény megegyezik a $25{ }^{\circ} \mathrm{C}$-on megfigyelttel: csak a mutáns hímek élethossza rövidebb a normálisnál. 
A következökben mászási teszttel megvizsgáltuk, hogy a mutáns hímek mozgási aktivitása hogyan változik hőstressz hatására. A $25{ }^{\circ} \mathrm{C}$-on mutatott, megközelítőleg $35 \%$-kal csökkent mozgási aktivitáshoz képest, 29 fokon hasonló arányt figyeltünk meg a moe[NES] hímek esetében a vad típussal összehasonlítva (53. ábra). Ez arra utal, hogy a hőstressz nem rontja tovább a mutáns hímek mozgásképességét, mely alapján megállapítható, hogy a mozgási problémák mögött nagy valószínüséggel nem a hsp gének kifejeződésének zavara áll.

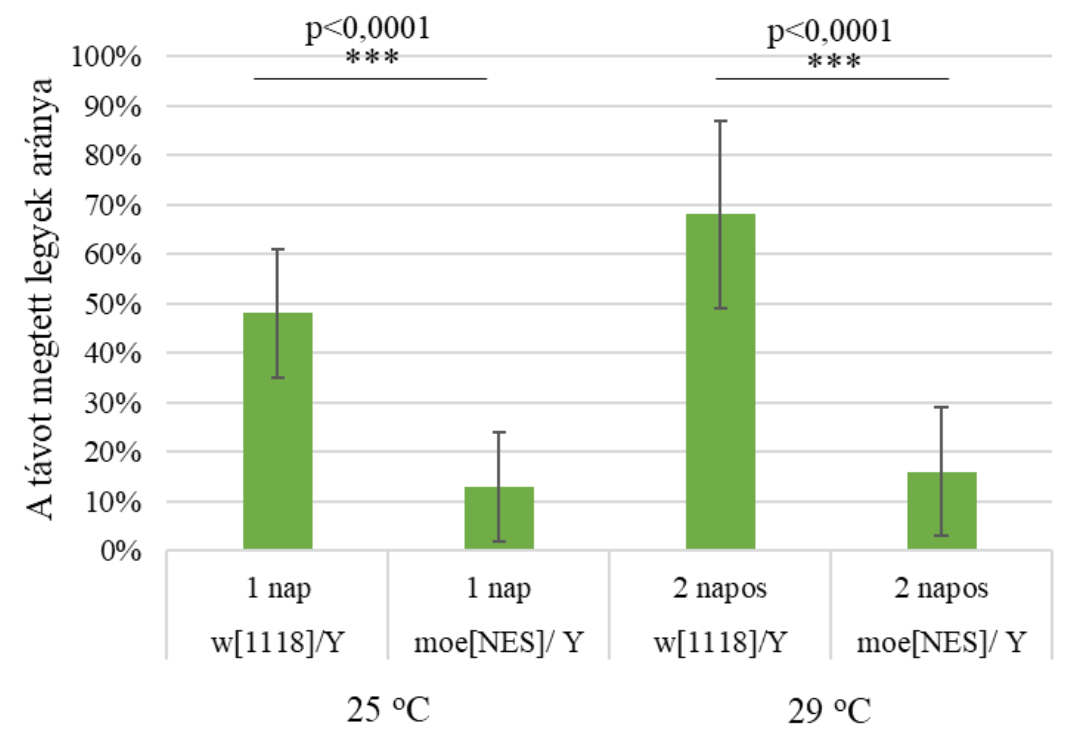

\section{3. ábra A moe[NES] hímek mozgási aktivitása nem változik hőstressz $\left(29^{\circ} \mathrm{C}\right)$} hatására.

\section{A MoeNES fehérje nem tud hösokk hatására a sejtmagban felhalmozódni}

Korábban már leírt megfigyelés szerint a Moesinnek különféle hatásokra (hősokk, ekdizon hormon, rael és Nup 98 RNSi) szignifikánsan megnő a sejtmagi mennyisége, így megvizsgáltuk a transzgénről termelt, GFP-vel jelölt MoeNES (54.A ábra), illetve a moe[NES] mutáns törzsben termelődő MoeNES (54.B ábra) fehérjéknek a hősokk által kiváltott sejtmagi halmozódását. A mikroszkópos felvételeken és a sejtmagi/citoplazmás fluoreszcencia intenzitási arányokból látható, hogy a MoeNES fehérje hősokk hatására a vad típusú Moesinnél számottevően gyengébb sejtmagi halmozódást mutat, mely további bizonyítékként szolgál arra, hogy a moe[NES] legyekben megfigyelhető csökkent hsp transzkriptszint, valamint hőérzékenység a Moesin sejtmagi hiányából fakad. 
A.

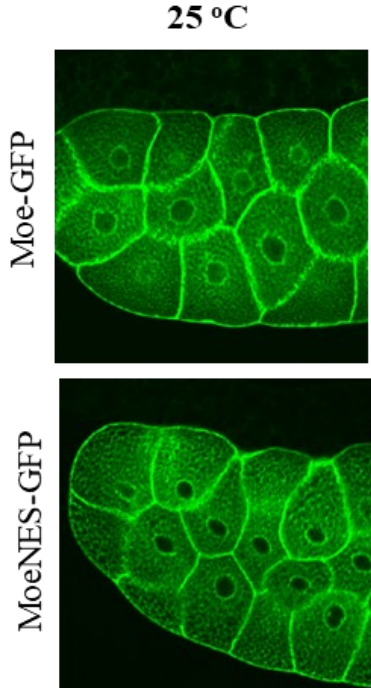

$25^{\circ} \mathrm{C}$
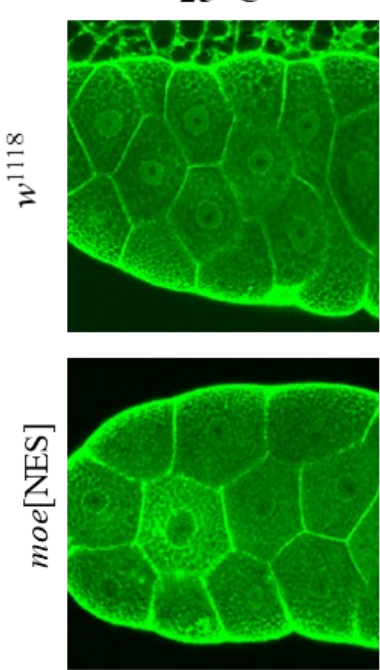

Hösokk $\left(37^{\circ} \mathrm{C}\right)$

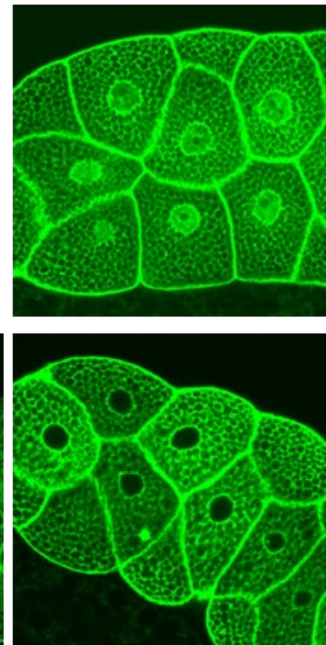

Hösokk $\left(37^{\circ} \mathrm{C}\right)$
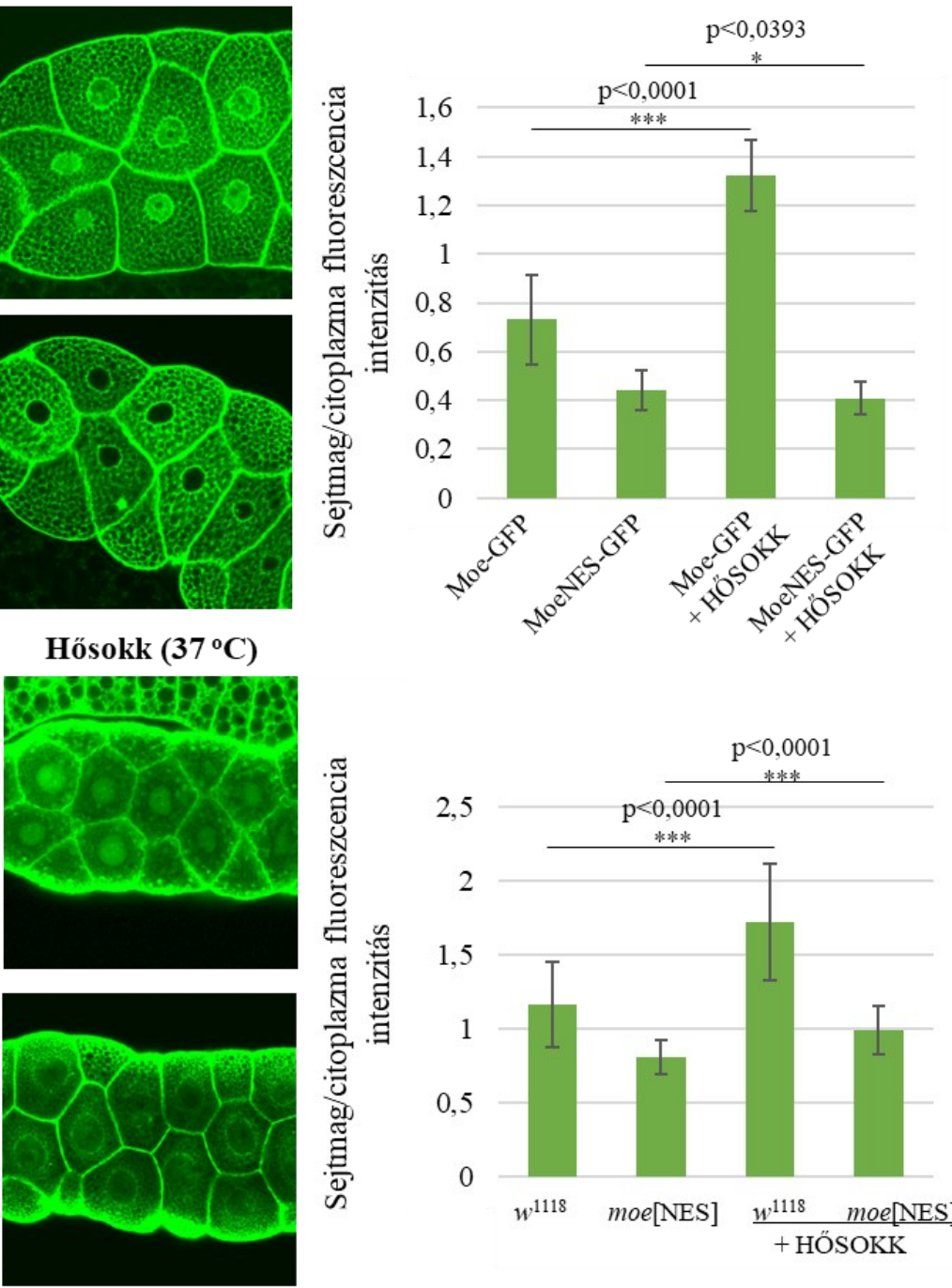

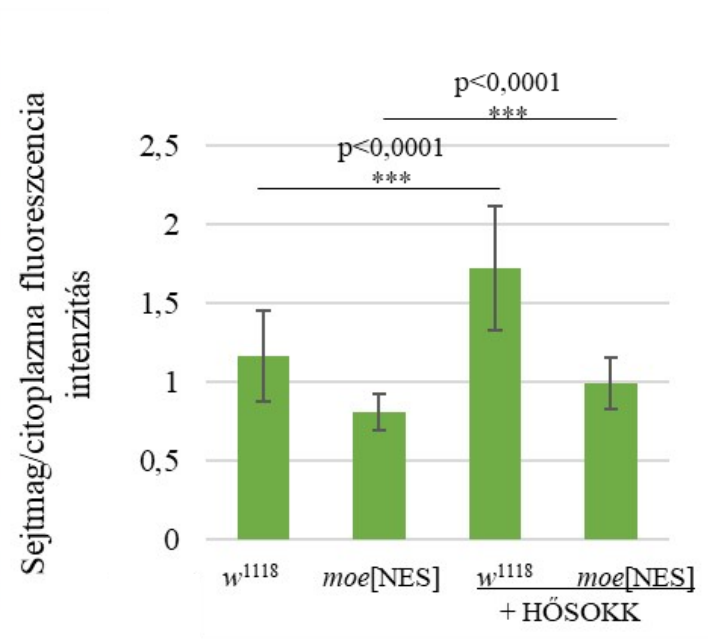

54. ábra A MoeNES fehérje szobahőn $\left(25^{\circ} \mathrm{C}\right)$, valamint hősokk $\left(37^{\circ} \mathrm{C}\right)$ hatására is jóval kisebb sejtmagi halmozódásra képes, mint a vad típusú Moesin. A transzgénről ektopikusan termelődő, GFP-vel jelölt Moesin fehérjével (Moe-GFP az A panelen) és a vad típusú fehérjével ( $w^{1118}$ a B panelen) ellentétben sem a transzgénről termelődő, GFPvel jelölt MoeNES fehérje (A), sem a moe[NES] törzsben expresszálódó MoeNES fehérje (B) nem mutat sejtmagi halmozódást hösokk hatására. Zöld - GFP ellenanyagfestés (A), illetve Moesin ellenanyagfestés (B).

\section{A hsp gének transzkripciósszintjeinek változása hösokk hatására}

A következőkben kvantitatív RT-PCR-rel megmértük az RNS szekvenálási kísérletben azonosított $h s p$ gének közül a $h s p 26$, hsp68 és hsp70Ab transzkriptek relatív mennyiségének hösokk hatására bekövetkező esetleges változását. Ehhez 3 napos 
$m o e[\mathrm{NES}] / m o e^{\mathrm{G} 0415}$ és $m o e^{\mathrm{G} 0415} / w^{1118}$ genotípusú nőstények petefészkeit $37{ }^{\circ} \mathrm{C}$-os vízfürdőben 30 percig Schneider's médiumban inkubáltuk. A kapott eredményekből megállapítható, hogy a hsp géneknél mért relatív transzkriptmennyiség a $m o e[\mathrm{NES}] /$ moe $^{\mathrm{G} 0415}$ nőstények petefészkeiben alacsonyabb, mint a kontrollnak használt $m o e^{\mathrm{G} 0415 / w^{1118}}$ genotípusú petefészkekben. Ez alapján kijelenthetjük, hogy a sejtmagi Moesin a hősokk során részt vesz a $h s p$ gének transzkripciójában, hiányában ezen gének transzkriptszintjei nem érik el a vad típusban mért értékeket. Minden bizonnyal ez az oka a moe[NES] mutáns legyekben megfigyelt hőérzékenységi fenotípusoknak is (54. ábra).

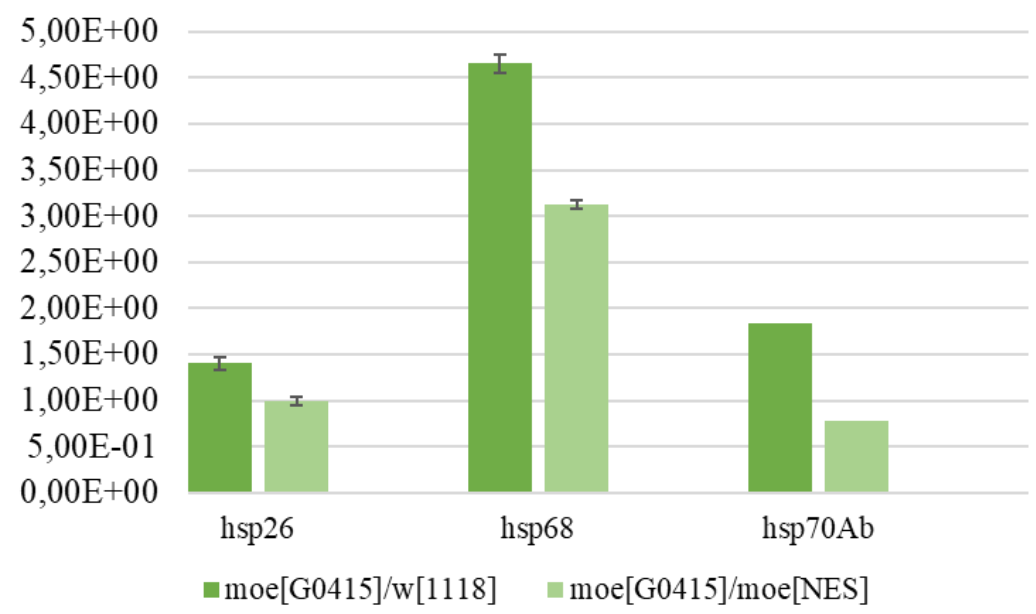

54. ábra. A hsp26, hsp68 és $h s p 70 A b$ hősokk gének transzkriptszintjeinek változása hősokk hatására. A grafikon adataiból megállapítható, hogy a moe $e^{\mathrm{G} 0415} / m o e[\mathrm{NES}]$ nőstényekben a $h s p$ gének kifejeződése gyengébb, mint a vad típusú legyek esetében. Ez az eredmény megerősíti, hogy a Moesin sejtmagi jelenléte fontos a $h s p$ gének transzkripciójához. 


\section{AZ EREDMÉNYEK MEGVITATÁSA ÉS TOVÁBBMUTATÁS}

Az ERM fehérjék a membrán alatt húzódó kortikális aktin hálózat és a transzmembrán fehérjék közötti kapcsolatok kialakításában vesznek részt, ezáltal fontos szerepet játszanak a sejtmigrációban, a T-sejt aktivációban (Neetha mtsai, 2013), a metasztázis kialakulásában (Clucaj és mtsai, 2014), valamint jelátviteli útvonalakat is befolyásolnak (Neisch és mtsai, 2011). Az utóbbi években vált bizonyítottá, hogy az ERM fehérjecsalád képviselői a sejtmagban is megtalálhatók (Batchleor és mtsai, 2004; Vilmos és mtsai, 2009).

A csoportunkban végzett korábbi munka eredményei szerint, a Drosophila melanogaster egyetlen ERM fehérjéje, a Moesin kis mennyiségben megtalálható a sejtmagban is, illetve sejtosztódás során kolokalizál az aktin hálózattal a mitotikus orsó körül (Vilmos és mtsai, 2016). A laboratóriumunkban végzett vizsgálatok azt bizonyították, hogy a Moesin részt vesz az mRNS-ek sejtmagból történő kiszállításában. Erre bizonyítékul szolgál, hogy a Moesin kolokalizál a Rael és pABP mRNS export faktor fehérjékkel a kromoszómákon, valamint hogy az mRNS exportban résztvevő Nup98 és Rae1 fehérjék mennyiségének csökkentése más mRNS export faktorokhoz hasonlóan a Moesin magi halmozódását váltja ki. További bizonyíték, hogy a moesin gén csendesítése mRNS felhalmozódást eredményez a vizsgált sejtek magjában (Kristó és mtsai, 2017).

A Moesin sejtmagi funkciójának megismerését elősegítő kísérleteinkben a fehérje sejtmagi importját és annak körülményeit vizsgáltuk. Ennek megfelelően a Moesin fehérjében azonosítottuk a kéttagú sejtmagi lokalizációs (NLS) szekvenciát, illetve megállapítottuk, hogy a szekvencia közelében elhelyezkedö, foszforilálható aminosavak (Y ${ }_{292}$ és $\mathrm{T}_{300}$ ) nem rendelkeznek a sejtmagi importot szabályozó funkcióval. Az ERM fehérjékről tudott, hogy képesek a dimerizációra, így lehetőség adódna a dimerként történő sejtmagi transzportra. Ebben az esetben, az NLS-törölt Moesin formák a sejtmagi halmozódás során a vad típusú Moesinnel kapcsolódva képesek lennének a magba jutni. Ugyanakkor a megfigyeléseink egyértelműen arra utalnak, hogy a Moesin monomer formában jut a sejtmagba, mivel az endogén Moesin jelenlétében sem képesek az NLS szekvenciát nem tartalmazó Moesin formák a sejtmagban halmozódni. A Moesin aktivációs állapota és sejtmagi transzportja közötti kapcsolat vizsgálata során azt is megfigyeltük, hogy az aktív, foszforilált formát utánzó $\mathrm{MoeT}_{559} \mathrm{D}$ izoforma kevésbé képes sejtmagi 
halmozódásra rael RNSi hatására, míg az inaktív formának tekintett $\mathrm{MoeT}_{559} \mathrm{~A}$, valamint a $\mathrm{PIP}_{2}$ kötésre képtelen MoeKA fehérje forma a vad típusú fehérjéhez hasonló módon képesek a sejtmagba jutni. Ezekböl az adatokból arra következtethetünk, hogy a Moesin elsősorban inaktív formában, PIP $_{2}$ kötés és az 559. pozícióban levő treonin foszforilációja nélkül jut a magba. A fehérje aktivációja oly módon gátolhatja a sejtmagi transzportot, hogy vagy az aktiváció során bekövetkező térszerkezeti változás akadályozza a megfelelő importin kötődését a Moesinhez, vagy az aktiválódott Moesint a citoplazmatikus aktin hálózathoz történő erős kötődése visszatartja a sejtmagi importtól. Ez utóbbi lehetőséget erősíti a laboratóriumunkban Kovács Zoltán által végzett vizsgálat is, mely azt bizonyította, hogy az F-aktin mennyiségének növelése a citoplazmában a Moesin sejtmagi import-dinamikájának drámai lecsökkenését eredményezi. A kísérletekkel azt is kimutattuk, hogy a Moesin importját nem befolyásolják a monomer aktin szintjében bekövetkező változások. A G-aktin szintet csökkentő Jasplakinolid kezelés, valamint a polimerizálódni képtelen $\mathrm{R}_{63} \mathrm{D}$ monomer aktin forma túltermelése sem befolyásolta a Moesin magi halmozódását, tehát importját.

A munkánk során az NLS szekvenciát sikerült ugyan meghatároznunk, ám a laboratóriumunkban végzett korábbi kísérletek azt mutatták, hogy a motívum törlése esetén nem lehet teljesen Moesin-mentes állapotot előidézni a sejtmagban. Ennek az az egyszerü oka, hogy a Moesin a mitózis után, a sejtmag újraszerveződésekor a kromoszómákhoz kapcsolódva a magba záródik, s ez a folyamat a fehérje NLS szekvenciája nélkül is megtörténik (Vilmos és mtsai, 2009). A mitózis után a sejtmagba bezáródott Moesin nagy része ugyanakkor nem hagyja el a sejtmagot, ott folyamatosan ellátja feladatait (Kristó és mtsai, 2017). Ezért annak érdekében, hogy Moesin-mentessé tegyük a Drosophila sejtmagjait, a moesin génbe egy sejtmagi export szekvenciát (NES) építettünk be a fehérjekódoló rész után. Így a sejtmagban közel Moesin-mentes állapotot tudtunk létrehozni, s ezzel lehetővé vált, hogy a Moesin sejtmagi hiányának következményeit megvizsgáljuk.

A létrehozott moe[NES] mutáns állatok esetében a megfigyelt fenotípusokat öröklődésük alapján osztályoztuk. Az anyai hatás következtében megjelenő fenotípusok közé a tergitelváltozásokat, a dominánsan megjelenő sterilitást, valamint részben az embrionális és lárvális letalitást soroltuk. Zigotikusan öröklődő fenotípusként megfigyeltük hímek esetében a csökkent mászóképességet és az élethossz rövidülését, továbbá a külső ivarszerv rotációját. Szintén zigotikus hátérrel rendelkeznek a moe[NES]/Y hímeket és nőstényeket egyaránt érintő csökkent hőtürés és részben az embrionális, illetve lárvális letalitás. Továbbá megfigyeltük az mRNS-ek halmozódását a lárvális nyálmirigyek sejtmagjában is, mely a magi mRNS export müködési zavarára utal. Munkánk további 
részében a MoeNES fehérje citoplazmatikus funkcióinak épségét ellenőriztük, emellett a megfigyelt fenotípusok mögött húzódó molekuláris okokat próbáltuk feltárni.

A mutánsokban a MoeNES fehérje citoplazmatikus funkciójának épségét bizonyítja, hogy egyrészt a null mutánssal ellentétben a homozigóta moe[NES] állatok életképesek, továbbá hogy a vizsgált anyai hatású faktorok (oskar mRNS, Staufen és Vasa fehérjék) mennyisége és eloszlása a mutáns anyák petesejtjeiben a vad típuséval megegyező. További bizonyíték a mutáns fehérje funkcionális épségére, hogy a mutánsokban a kortikális aktin hálózat és a dajkasejtek magját pányvázó aktinkötegek szerveződése is megfelelö. Az aktivált, foszforilált ERM fehérjékre specifikus immunfestéssel kimutattuk továbbá, hogy a MoeNES fehérje a vad típushoz hasonló módon aktiválódik és lokalizálódik, mely megfigyelésünket a nyálmirigyeken Moesin ellenanyaggal végzett vizsgálataink is megerősítették. Ezen vizsgálatok azt bizonyították, hogy a MoeNES fehérje citoplazmatikus funkciói nem sérültek, mivel a citoszkeletális rendszer szervezését, illetve szabályozását a vad típusú Moesinhez hasonlóan ellátja.

A további kísérleteink a megfigyelt fenotípusok molekuláris okainak felderítését célozták. A sterilitással kapcsolatban igazoltuk, hogy a moe[NES] nőstények petefészkeiben az ivarvonal őssejtek, valamint a képződő embrióikban az ivarsejtek megfelelően kifejlődtek. Ugyanakkor a moe[NES] anyák adult korú utódaiban nem tudtunk ivarvonal őssejteket, ennélfogva ivarsejteket sem azonosítani, így a sterilitás okának felderítését az utódok korai embrionális állapotának tanulmányozásával folytattuk. A fejlődő embriókban a Vasa-GFP fehérje nyomon követésével megfigyeltük, hogy az ivarvonal őssejtek az embrió poszterior pólusán megfelelő időben és számban kialakulnak, azonban a gasztruláció kezdeti szakasza során elveszítik a Vasa-GFP jelet. Ennek oka lehet az identitásuk elvesztése, apoptózis, vagy a transzpozonok szabályozásában bekövetkező zavar. Ennek megfelelően eddig a moe[NES] anyák petefészkeiben a transzpozonok esetleges túlmüködését teszteltük, és bizonyítottuk, hogy a transzpozonok szabályozása a mutáns legyek esetében megfelelően müködik, nem ez okozza az ivarsejtek eltünését. A továbbiakban a moe[NES]/+ anyák embrióin az apoptózist jelző Caspase, illetve Acridine Orange, valamint az idő előtti transzkripciós aktivitás beindulásának kimutatására szolgáló festéseket tervezzük elvégezni, hogy az ivarsejtek elveszésének molekuláris okait feltárjuk.

A moe[NES] legyek sejtmagjában megjelenő mRNS halmozódás nagy valószínüséggel az mRNS exportban, illetve a transzkripcióban bekövetkező hiba miatt alakul ki. Ez jól magyarázhatja a megfigyelt fenotípusok kialakulását, ezért ennek vizsgálatára teljes mRNS szekvenálást végeztünk a mutáns legyeken. Az eredmények azt 
mutatták, hogy a moe[NES] mutánsban számos gén átíródásának a megváltozott szintje, az esetek egy részében transzkriptszint növekedést, míg más részében csökkenést tapasztaltunk. A Moesin eddig igazolt sejtmagi funkciója az mRNS-ek sejtmagból való kiszállításához köthető, de vannak adataink, melyek arra utalnak, hogy egyes gének esetében az átírásukban is fontos szerepet játszik. Ennek megfelelően mutáns állatokban a csökkent mRNS szint a transzkripció, míg a megnövekedett mRNS mennyiség a sejtmagi export elakadása miatt következhet be.

A transzkripciósszint csökkenését mutató gének között hat hösokk gént (hsp70Aa, hsp70Ab, hsp70Ba, hsp68, hsp26, hsp23) azonosítottunk abból a 85 génböl, melyek a Flybase adatbázisa alapján részt vesznek a környezeti stimulusokra adott válaszreakciókban. Ezen gének csökkent expressziós szintje a moe[NES] mutánsokban hozzájárulhat szinte minden megfigyelt fenotípus kialakulásához. A transzkripciósszint csökkenését mutató gének között számos olyat is azonosítottunk, melyek az oogenezisben, valamint az ivarsejtek kialakulásában játszanak szerepet, így az általuk kódolt fehérjék mennyiségének csökkenése szintén hozzájárulhat a sterilitás kialakításához. Mint említettem, a csökkent expressziós szintet mutató gének esetében feltételezhető, hogy a Moesin elősegíti az átírásukat, esetleg szerepet játszik az mRNS-eik érésében. Ez nagy valószínüséggel igaz a kísérletben meghatározott hat hősokk gén esetében, ugyanis a hőtolerancia teszt, a qPCR analízisek és az immunfestések is ezt támasztották alá. Az elképzelést tovább támogatja az a laboratóriumunkban tett megfigyelés is, mely szerint hőstressz hatására a Moesin a hősokk géneken, köztük a dolgozatban vizsgált hat hősokk génen is erős felhalmozódást mutat (Kristó és mtsai, 2017; Kristó Ildikó nem publikált eredménye). Ezek a kísérletek hősokk transzgének segítségével azt is igazolták, hogy a Moesin nem a hősokk gének speciális, ún. puffszerkezetének kialakításához, hanem a transzkripciójához szükséges. További kísérletek elvégzése kell a jövőben ahhoz, hogy pontosan megértsük a Moesin szerepét a hősokkban, a hősokk gének transzkripciójában.

A moe[NES] mutánsokban a transzkripciós aktivitás növekedését mutató gének által ellátott feladatok között szintén nagy arányban találtunk az oogenezishez, az ivarsejtek kialakulásához, valamint a mozgáshoz kapcsolható funkciókat. A mutánsokban megfigyelt csökkent mászóképesség oka lehet az izom és a neuronális fejlödésben, illetve az izommüködésben szerepet játszó gének transzkriptszintjeinek a megemelkedése. A transzkripciós aktivitási emelkedés legvalószínübb oka az lehet, hogy a Moesin ezeknek a géneknek az esetében az mRNS-eik sejtmagi exportjában vesz részt. Így a Moesin sejtmagi hiányából adódó lelassult mRNS exportot a sejt az érintett gének transzkripciós aktivitásának 
emelésével próbálja ellensúlyozni. Természetesen annak a lehetősége is fennáll, hogy a Moesin ezen gének átírását negatív módon befolyásolja, így eredményez a NES motívum következtében csökkent sejtmagi Moesin mennyiség megemelkedett transzkripciót.

$\mathrm{Az}$ expressziósszint változást mutató gének egy különleges csoportja, 386 gén esetében a transzkripciósszint változás a moe[NES] mutáció domináns hatása következtében alakult ki: a mutáns allél egyetlen kópiája elegendő volt a változás létrejöttéhez. A csoport tagjainak jelentős része szintén az egyedfejlödésben, valamint a környezeti hatásokra adott válaszreakciókban vesz részt. A Flybase adatbázisa alapján ezek között hét olyan gént azonosítottunk, melyek az ivarvonal őssejtek fejlődésében tölt be szerepet, így mRNS szintjeik csökkenése részben felelős lehet a megfigyelt domináns sterilitás megjelenéséért.

Mint ismeretes, domináns hatás kialakulásának a hátterében elsősorban az érintett fehérje dimerizációs képességének megváltozása áll. Az ERM fehérjék egyik fontos jellemzője, hogy egymással N- és C-terminális doménjeik révén képesek fej-farok irányban stabilan dimerizálódni, sőt egyes szerzők szerint még az oligomerizáció lehetősége is fennáll (Gary és Bretscher, 1995; Bhartur és Goldenring, 1998). Az ERM fehérjék dimerképződésének funkcionális jelentősége ugyan egyelőre nem ismert, ám napjainkban kezd egyre inkább világossá válni, hogy feladatuk ellátásához alapvetően szükséges (Michie és mtsai, 2019). Ugyanakkor az ERM fehérjék dimerizációjuk után továbbra is képesek a kötöpartnereikkel kölcsönhatásba lépni (Phang és mtsai, 2016), így feltételezhető, hogy egyes funkcióit a Drosophila Moesin is dimer formában látja el.

Mindezek alapján az általunk megfigyelt domináns hatás egyik magyarázata az lehet, hogy a NES motívum a dimerek irreverzibilis kialakulását eredményezi, így a MoeNES fehérje a heterozigóta legyekben jelen lévő endogén, vad típusú Moesin fehérjékkel összekapcsolódva heterodimer formában leköti a sejtek endogén Moesin mennyiségét, ezáltal gátolja azok monomer formában betöltött funkcióit. Az ily módon létrejövő antimorf hatás funkcióvesztéses fenotípus kialakulásához vezet. Elképzelhető azonban az is, hogy a NES motívum a dimer állapothoz kapcsolható aktivitások sérülését vagy hiányát is okozza. Továbbá az sem zárható ki teljesen, hogy a Moesin aktinkötő doménjének végére beépített NES módosítja a fehérje F-aktinkötő képességét, aminek következtében alakul ki a domináns hatás: lefoglalja a kötőpartnereit anélkül, hogy az aktinhoz horgonyozná azokat. Ez utóbbi lehetőségnek azonban ellentmond, hogy a kísérleteink szerint a MoeNES fehérje citoplazmatikus funkciói és a kortikális aktinhoz való lokalizálása normális.

A NES fehérjemotívum miatt kialakult domináns hatás következtében kialakult sterilitás, valamint az egyes gének transzkriptszintjében kialakult változás, ugyan a kísérleti 
rendszerünk nem várt mellékhatása, ám mivel eddig semmi jelét nem tapasztaltuk a moe[NES] mutánsban a citoplazmatikus funkciók sérülésének, ezért feltételezhető, hogy a mellékhatásoknak egy része a sejtmagi funkciókkal függ össze. A NES szekvencia okozta domináns mellékhatás megértésére a NES jelölést hordozó fehérje dimerizációs és aktinkötő képességét vizsgáló ún. micro scale thermophoresis (MST) kísérletek a dolgozat megírásakor folyamatban vannak. Reményeink szerint az eredmények új információval fognak szolgálni a Moesinnek nemcsak a sejtmagi, hanem dimerként betöltött funkcióiról is.

Eredményeink alapján elmondhatjuk, hogy eddigi ismereteinkkel szemben az ERM fehérjék fontos szerepe nem csak a citoplazmára korlátozódik, hanem sejtmagi jelenlétük is alapvetően fontos az élőlények számára. Reményeink szerint a Drosophila Moesin sejtmagi funkcióinak felderítése az ERM fehérjéken túl a sejtmagi aktin tevékenységének megértéséhez is közelebb visz majd bennünket. 


\section{TARTALMI ÖSSZEFOGLALÓ}

Az utóbbi években az aktin mellett már számos sejtváz kialakításában résztvevő fehérjéről kiderült, hogy jelen van a sejtmagban. Dolgozatomban az aktinkötő, citoszkeletális Ezrin-Radixin-Moesin (ERM) fehérjék egyetlen Drosophila képviselőjének, a Drosophila Moesinnek a sejtmagi szerepét tanulmányoztuk, mivel már korábban bizonyítást nyert az ERM fehérjék magi lokalizációja, de a sejtmagi jelenlétükhöz mindeddig kevés funkciót sikerült társítani. A Moesin sejtmagi aktivitásáról szerzett tudásunk föként biokémiai megközelítések eredménye, ezért úgy gondoljuk, hogy az általunk az ecetmuslicában végzett in vivo kísérletek kiegészítik, illetve árnyalják eddigi ismereteinket a Moesinnek a sejtmag működésében betöltött szerepéről.

A többi citoszkeletális fehérjéhez hasonlóan a Drosophila Moesin sejtmagi funkciójának teljes megismerését megnehezíti, hogy a sejtmagi importmechanizmusa nem ismert, így a nukleáris és citoplazmatikus funkciók elkülönítése nehézkes. Ennek a problémának a megoldására két megközelítést alkalmaztunk. Egyrészt elkezdtük a Moesin sejtmagi importmechanizmusának és szabályozásának az elemzését, másrészt ezzel párhuzamosan egy nukleáris export szignált (NES) építettünk be a moesin génbe a CRISPRCas9 rendszerrel, melynek alkalmazásával közel Moesin-mentes állapotot hoztunk létre, így teremtve meg a lehetőséget a sejtmagi hiány következményeinek vizsgálatára.

A Moesin sejtmagi importjának vizsgálata során a korábban már a NucPred program által azonosított potenciális NLS szekvenciák tesztelését, majd az így meghatározott NLS motívum pontos szerkezetét és szabályozását, végül a Moesin aktivációs állapotának hatását tanulmányoztuk. A kísérletek során a laboratóriumunkban előzetesen jellemzett NLS szekvenciától $\left(\mathrm{R}_{294} \mathrm{RRK}_{297}\right)$ 13. aminosavra $\mathrm{N}$-terminális irányban azonosítottunk egy másik NLS motívumot $\left(\mathrm{K}_{279} \mathrm{R}_{280}\right)$, és igazoltuk, hogy a Moesin sejtmagi lokalizációs szekvenciája kéttagú. Ezután az NLS közelében a 292., és a 300. pozícióban elhelyezkedő, foszforilálható tirozin és treonin aminosavakról bizonyítottuk be, hogy nem rendelkeznek az NLS-t szabályozó funkcióval. Az állandóan aktivált konformációban lévő $\mathrm{MoeT}_{559} \mathrm{D}$, valamint az inaktívnak tekintett MoeT559A fehérje izoformák alkalmazásával pedig azt is kimutattuk, hogy az inaktív forma a vad típussal megegyező módon, míg az aktivált ennél kisebb mértékben képes a sejtmagba jutni.

Mivel kísérleteink során az is világossá vált, hogy a MoeT ${ }_{559} \mathrm{~A}$ nem tekinthető teljesen inaktív fehérjének, mert képes a moesin null mutációját menekíteni, ezért egy 
biztosan inaktív fehérje formát, a PIP 2 kötésére képtelen MoeKA izoformát is létrehoztuk. Mivel ez az izoforma is a vad típussal megegyező módon képes a sejtmagokban halmozódni, kijelenthetjük, hogy a sejtmagi import a fehérje inaktív állapotában is megtörténik, valamint hogy a Moesin transzportjához nem szükséges $\mathrm{PIP}_{2}$ kötése. A monomer aktin hatását vizsgálva pedig arra a következtetésre jutottunk, hogy sem a csökkent, sem a megemelkedett citoplazmatikus G-aktin szintnek nincsen hatása a Moesin sejtmagi transzportjára.

A sejtmagi Moesintől mentes állapot létrehozásához a CRISPR-Cas9 rendszerrel négy egymástól független mutáns vonalat alapítottunk. Ezek a moe[NES] vonalak ugyanazokat a változatos, összetett fenotípusokat mutatták, melyek között fejlődési rendellenességeket, élettani problémákat, valamint domináns anyai hatású sterilitást figyeltünk meg. A domináns anyai hatás esetében a sterilitás a moe[NES] nőstények utódaiban jelenik meg, abban az esetben is, ha az anyák csak egyetlen kópiában hordozzák a moe[NES] allélt.

A következőkben a fenotípusokat részletesen jellemeztük és megállapítottuk, hogy a tergitelváltozások, a dominánsan megjelenő sterilitás, valamint részben az embrionális és lárvális letalitás anyai hatás következtében alakulnak ki. Ezzel szemben a csökkent mászóképesség és a hímek rövidebb élethossza, valamint a genitáliájuk rotációja zigotikus eredetű probléma. Szintén zigotikus hátérrel rendelkeznek a moe[NES]/Y hímeknél és nőstényeknél egyaránt megfigyelt csökkent hőtürés és részben az embrionális, illetve lárvális letalitás.

Mivel a mutáns fenotípusokat legalább részben okozhatja mellékhatásként a MoeNES fehérje citoplazmatikus funkcióinak sérülése is, ezért ellenőrző kísérleteket végeztünk. Ezek azt mutatták, hogy a moe[NES] mutáns állatokban a kortikális, a sejtmagot pányvázó, és az anyai hatású faktorokat lokalizáló aktin hálózatok szerveződése és müködése nem érintett. A MoeNES fehérje molekuláris müködésének épségére irányuló további kísérletek ezen felül mutatják, hogy a fehérje képes foszforilálódni, ezáltal aktiválódni, és a foszforilált MoeNES a vad típusú Moesin fehérjéhez hasonlóan lokalizál a sejtek membránjához. Igazoltuk végül azt is, hogy a NES motívumot felismerő CRM1 transzport útvonalat nem terheli meg a MoeNES fehérje jelenléte. Mindezek az eredmények azt bizonyítják, hogy a MoeNES fehérje jól ellátja citoplazmatikus funkcióit, a vad típusú Moesinhez hasonló módon képes a citoszkeletális rendszer megszervezésére.

A további kísérleteink a megfigyelt fenotípusok molekuláris okainak felderítését célozták. Így a sterilitással kapcsolatban igazoltuk, hogy a moe[NES] anyák embrióinak ivarsejtjei a gasztruláció kezdeti szakasza során elveszítik a sorsukat meghatározó Vasa 
fehérjét. Ennek okait keresve eddig azt bizonyítottuk, hogy a transzpozonok szabályozása a mutáns anyákban megfelelően müködik, nem ez okozza az embriók ivarsejtjeinek eltünését.

Minthogy a sejtmagi Moesin bizonyítottan részt vesz az mRNP komplexek sejtmagi szállításában, megvizsgáltuk a hemizigóta moe[NES] mutáns hím lárvák nyálmirigyében az mRNS-ek eloszlását. Az eddigi munkáinkkal összhangban azt találtuk, hogy a Moesin sejtmagi hiánya mRNS felhalmozódást eredményez a moe[NES] állatok sejtmagjaiban, ami egyértelműen a magi mRNS export hibáját jelzi. A továbbiakban annak igazolására, hogy a moe[NES] legyekben azonosított fenotípusok kialakításában szerepet játszhat a Moesin sejtmagi hiányából adódó sérült mRNS szállítás vagy transzkripció, teljes mRNS szekvenálást végeztünk a moe[NES] nőstények petefészkeiből izolált teljes mRNS populáción. Eredményként azt kaptuk, hogy a közel 13000 vizsgált gén közül 371-nek a vad típushoz képest emelkedett a transzkriptszintje, míg 315 gén esetében csökkent. Az emelkedett transzkriptszinttel rendelkező géneknél legvalószínűbb, hogy a Moesin sejtmagi hiánya az mRNS-eik szállításának sérülését okozza, amelyet a sejtek emelkedett génaktivitással próbálnak ellensúlyozni. A csökkent transzkripció hátterében pedig a feltételezésünk szerint a Moesinnek az adott gén átírásában játszott pozitív szerepe állhat.

A transzkriptszint csökkenését mutató gének között hat olyan gént is találtunk (hsp70Aa, hsp70Ab, hsp70Ba, hsp68, hsp26, hsp23), melyek egyértelmüen felelősek lehetnek a moe[NES] mutáció okozta csökkent hötürésért, valamint részben a sterilitás kialakulásáért. A moe[NES] mutánsokban azonosított hsp gének sérült transzkripcióját erösítik meg az RT-qPCR-rel végzett kísérleteink is, melyekben hőstressz körülmény között mértük a $h s p$ gének aktivitását. Az eredmények alapján a moe[NES] legyekben a $h s p$ gének ( $h s p 26$, hsp68 és hsp70Ab) transzkripciója megemelkedik, de a Moesin sejtmagi hiánya miatt a relatív transzkript mennyiség nem éri el a vad típusban mért értékeket, mely nyilvánvalóan a mutánsokban megfigyelt hőérzékenységhez vezet. Mindezeken túl 386 olyan gént is azonosítottuk, melyek esetében egyetlen kópia moe[NES] allél, azaz domináns hatás okozta a transzkriptszint megváltozását. Ezen gének között 7 olyat találtunk (boule, Daughters against dpp, division abnormally delayed, Epidermal growth factor receptor, nanos, torso-like, valamint a traffic jam), melyek fontos szereppel bírnak az ivarvonal őssejtek fejlődésében, ezáltal fontos komponensei lehetnek a domináns sterilitás kialakulásának.

Összegzésként eredményeink alapján elmondható, hogy a munkánk legfontosabb, új eredménye az, hogy a Moesin fontos résztvevője a hsp gének expressziójának. A NES szignál miatti kis sejtmagi Moesin mennyiség következtében a hsp mRNS-ek szintje 
alacsony, mely végül a moe[NES] legyekben megfigyelt hőérzékenységhez vezet. Eredményeink egyértelmüen arra utalnak, hogy eddigi ismereteinkkel szemben az ERM fehérjék alapvető szerepe nem csak a citoplazmára korlátozódik, hanem sejtmagi jelenlétük is fontos az élőlények számára. Reményeink szerint a Drosophila Moesin sejtmagi funkcióinak részletes felderítése az ERM fehérjék, illetve ezen túl az aktin sejtmagi tevékenységének megértéséhez is közelebb visznek majd. 


\section{SUMMARY}

In the recent past numerous cytoskeletal proteins have been found in the nucleus. Although the nuclear localization of the actin-binding, cytoskeletal Ezrin-Radixin-Moesin (ERM) proteins has been previously demonstrated (Batchelor et al., 2003) but only few functions have been associated with the nuclear presence of ERMs. Therefore, we investigated the nuclear functions of Drosophila Moesin, the sole Ezrin-Radixin-Moesin family member in the fly. Our knowledge about the nuclear activity of Moesin is based mainly on biochemical approaches, thus our in vivo experiments complement and refine the data about nuclear Moesin.

Similarly to the case of other cytoskeletal proteins, the details of nuclear transport of Moesin are not known, therefore the direct study of its nuclear function is not possible at the moment. We overcame this problem by characterizing the nuclear localization signal of Moesin and in parallel, by excluding the protein from the nucleus. For the latter aim, with the help of the CRISPR-Cas9 system, we tagged the moesin gene with a nuclear export signal (NES). As a result, the MoeNES protein was constantly cleared out from the nucleus while it could still perform its cytoplasmic functions.

During the investigation of the nuclear import of Moesin we tested the potential NLS motifs predicted by the NucPred software, then analysed the exact sequence and regulation of the identified NLS, and explored the effect of Moesin's activation on its nuclear import. With 13 amino acid positions upstream from the NLS sequence described previously in our laboratory $\left(\mathrm{R}_{294} \mathrm{RRK}_{297}\right)$, we identified a second NLS motif $\left(\mathrm{K}_{279} \mathrm{R}_{280}\right)$, and confirmed that the NLS is in fact bipartite. We also showed that the potentially phosphorylatable tyrosine and threonine residues at positions 292 and 300, near the NLS have no import regulatory function. With the help of the constitutively activated $\mathrm{MoeT}_{559} \mathrm{D}$ and the inactive $\mathrm{MoeT}_{559} \mathrm{~A}$ protein isoforms we demonstrated that Moesin can normally translocate into the nucleus in its inactive form, while the activated conformation of Moesin inhibits import.

Our experiments with transgenic Drosophila lines demonstrated that the inactive form of $\mathrm{MoeT}_{559} \mathrm{~A}$ is not fully inactive because it was able to rescue the moe[PG26] null mutation, therefore we created the MoeKA form which has no $\mathrm{PIP}_{2}$ binding capacity making it a true non-functional protein. The nuclear accumulation of this protein form was similar to the wild-type which suggests that Moesin can be transported into the nucleus in its inactive conformation and that the nuclear import of the protein does not require $\mathrm{PIP}_{2}$ binding. To 
test if monomeric actin binding can regulate the nuclear import of Moesin, we increased as well as decreased the intracellular G-actin level and found, that the nuclear import of Moesin is not affected by the G-actin level in the cytoplasm.

To investigate the effects of the nuclear absence of Moesin we established four mutant moe[NES] fly lines with the CRISPR-Cas9 method. All the mutant lines exhibited the same phenotypes such as developmental defects, physiological problems and $100 \%$ sterility caused by dominant maternal effect. In the case of dominant maternal sterility, moe[NES] mothers are fertile, but the sterility develops in their progenies even if they carry only a single copy of the moe[NES] allele.

In the next phase of our work we performed the detailed analysis of the observed phenotypes and found that dominant sterility, malformations of the tergits, and partly the embryonic and larval lethality are caused by maternal effect. In contrast, the decreased climbing activity, shorter life span and the genitalia rotation of the males, as well as the decreased heat tolerance of both sexes and the embryonic and larval lethality are of zygotic origin.

Since the mutant phenotypes might be due at least partly to the impairment of the cytoplasmic activity of the MoeNES protein, we conducted control experiments. These experiments revealed that in the moe[NES] mutant animals the organization and functioning of the actin networks formed at the cell cortex, positioning the nuclei in the nurse cells, or localizing maternal factors (oskar mRNA and Vasa-GFP) in the oocyte, are normal. Further work testing the molecular functions of the MoeNES protein proved that the protein is activated through phosphorylation correctly and it localizes to the cell cortex similarly to the wild type Moesin. Finally, we demonstrated that the CRM1 nuclear export pathway recognizing the NES tag of Moesin is not overloaded, it is functioning normally. The control experiments together strongly suggest that the cytoplasmic functions and the cytoskeleton organizing activities of the MoeNES protein are intact.

In the next set of our experiments we focused on the molecular mechanisms behind the observed phenotypes. About the sterility of moe[NES] progenies we showed that the germ cells in the embryos of moe[NES] mothers at the beginning of gastrulation lose the Vasa protein which determines germ cell fate. The investigation of the reasons for this phenomena revealed so far that the silencing of transposons in the germ line is normal thus, it does not account for the observed sterility.

Because Moesin is involved in the nuclear transport of mRNP complexes, we analysed the distribution of mRNAs in the salivary gland cells of moe[NES] mutant male larvae. In 
accordance with our previous findings, mRNA accumulation was detected in the nuclei which provides evidence for the disruption of the nuclear mRNA export. To further strengthen the idea that impaired mRNA transcription and/or export is responsible for the phenotypes observed in moe[NES] mutant animals, we performed mRNA sequencing experiment on the whole RNA population isolated from the ovaries of mutant females. We found that out of the 13000 genes examined 371 were upregulated and 315 genes were downregulated in the mutant as compared to the control. The increase in transcriptional activity is most likely due to the defect of the nuclear export of mRNAs which in turn is compensated by the cell through forced transcription. We hypothesize that the decrease in transcription of the genes in moe[NES] mutant animals is caused by the lack of the positive role played by Moesin in transcription. Among the genes with decreased activity we identified six ( $h s p 70 A a, h s p 70 A b, h s p 70 B a, h s p 68$, hsp26, hsp23) which most likely can be responsible for the reduced heat tolerance and possibly contribute also to the sterility observed in moe[NES] mutants. The impaired transcription of $h s p$ genes observed in moe[NES] mutants is also confirmed by our RT-qPCR experiments. In these experiments we measured the activity of $h s p$ genes during heat shock. The results suggest that the transcription of $h s p$ genes ( $h s p 26, h s p 68$, and $h s p 70 A b)$ is increased in moe[NES] flies but due to the lack of nuclear Moesin, the relative transcript level does not reach the values measured in the wild type. This weaker transcription of hsp genes in turn leads to heat sensitivity in mutant flies. In addition to the genes with altered expression level, we also found 386 genes, where a single copy of the moe[NES] allele, in other words, dominant effect was able to modify the gene expression activity. Seven of these genes (boule, Daughters against dpp, division abnormally delayed, Epidermal growth factor receptor, nanos, torso-like, and traffic jam) play essential role in germ cell development, thereby their expression changes might be responsible partially for the development of dominant sterility.

In sum, based on our results we can tell that the most significant, new finding of our work is that Moesin is an important player of the expression of $h s p$ genes. The low amount of nuclear Moesin caused by the NES signal leads to reduced $h s p$ mRNA level which results in the decreased heat tolerance of moe[NES] flies. Our findings clearly demonstrate that the fundamental role of ERM proteins is not limited to the cytoplasm, but their presence in the nucleus is also important for the organism. We hope that the deeper insight into the nuclear functions of Drosophila Moesin will help us in the future to better understand the nuclear functions of ERM proteins as well as of actin. 


\section{FÜGGELÉK}

\begin{tabular}{|c|c|}
\hline qPCR primer neve & Primer szekvenciája (5'-3') \\
\hline qHsp26_Fw & TGTGGGCAAGGATGGATTCCA \\
\hline qHsp26_Rev & TGGCGCATGATGTGACCATG \\
\hline qHsp68_Fw & AACTTTGGACAGCAAGCTGG \\
\hline qHsp_68_Rev & AATATAGGGGGACTTCGTTTGA \\
\hline qHsp70Ab_Fw & GTGGAGATTATCGCCAACGAC \\
\hline qHsp70Ab_Rev & TCATGGCCACCTGGTTCTTAG \\
\hline
\end{tabular}

\begin{tabular}{|c|c|c|}
\hline $\begin{array}{c}\text { Moesin } \\
\text { forma } \\
\text { neve } \\
\end{array}$ & Primer neve & Primer szekvenciája (5' - 3') \\
\hline \multirow{2}{*}{$\begin{array}{c}\text { Moe- } \\
\Delta \text { NLS1 }\end{array}$} & $\begin{array}{c}\text { Moe- } \\
\Delta \text { NLS1_forward }\end{array}$ & CGTGTCCGCATCAACATTCTGGCCCTCTGC \\
\hline & $\begin{array}{c}\text { Moe- } \\
\Delta \mathrm{NLS} 1 \_ \text {reverse }\end{array}$ & GCAGAGGGCCAGAATGTTGATGCGGACACG \\
\hline \multirow{2}{*}{$\begin{array}{l}\text { Moe- } \\
\text { Y292A }\end{array}$} & $\begin{array}{c}\text { Moe- } \\
\text { Y292A_forward }\end{array}$ & GCAACCACGAGCTGGCCATGCGTCGCCGCA \\
\hline & $\begin{array}{c}\text { Moe- } \\
\text { Y292A_reverse }\end{array}$ & TGCGGCGACGCATGGCCAGCTCGTGGTTGC \\
\hline \multirow{2}{*}{$\begin{array}{l}\text { Moe- } \\
\text { Y292D }\end{array}$} & $\begin{array}{c}\text { Moe- } \\
\text { Y292D_forward }\end{array}$ & CAACCACGAGCTGGACATGCGTCGCCG \\
\hline & $\begin{array}{c}\text { Moe- } \\
\text { Y292D_reverse }\end{array}$ & CGGCGACGCATGTCCAGCTCGTGGTTG \\
\hline \multirow{2}{*}{$\begin{array}{l}\text { Moe- } \\
\text { T300A }\end{array}$} & $\begin{array}{c}\text { Moe- } \\
\text { T300A_forward }\end{array}$ & CCGCAAGCCGGACGCCATCGATGTGCA \\
\hline & $\begin{array}{c}\text { Moe- } \\
\text { T300A_reverse }\end{array}$ & TGCACATCGATGGCGTCCGGCTTGCGG \\
\hline \multirow{2}{*}{$\begin{array}{l}\text { Moe- } \\
\text { T300D }\end{array}$} & $\begin{array}{c}\text { Moe- } \\
\text { T300D_forward }\end{array}$ & GCCGCAAGCCGGACGACATCGATGTGCAGC \\
\hline & $\begin{array}{c}\text { Moe- } \\
\text { T300D_reverse }\end{array}$ & GCTGCACATCGATGTCGTCCGGCTTGCGGC \\
\hline \multirow{4}{*}{ Moe-KA } & Moe-KA_forward & GTTCATCATCAAGCCGATCGACGCGGCGGCTCCGG \\
\hline & Moe-KA_reverse & GTCGATCGGCTTGATGATGAACGCCGCCTCCGAGAACG \\
\hline & \begin{tabular}{|c|} 
pDONR221_3522- \\
3555_forward
\end{tabular} & CGCTGACTTGACGGGACGGCGCAAGCTCATGAC \\
\hline & $\begin{array}{c}\text { pDONR221_3522- } \\
\text { 3555_reverse }\end{array}$ & GTCATGAGCTTGCGCCGTCCCGTCAAGTCAGCG \\
\hline
\end{tabular}




\section{RÖVIDÍTÉSEK JEGYZÉKE}

\begin{tabular}{|c|c|}
\hline ARP & aktinszerü fehérje (Actin Related Protein) \\
\hline ATP & Adenozin-trifoszfát \\
\hline CRISPR & $\begin{array}{l}\text { Clustered regularly interspaced short } \\
\text { palindromic repeat }\end{array}$ \\
\hline Crm1 & Chromosomal Maintenance 1 \\
\hline DAPI & Diamino-fenilindol \\
\hline DMSO & dimetil-szulfoxid \\
\hline EM & Emerin \\
\hline ERM & Ezrin-Radixin-Moesin \\
\hline Exp6 & Exportin 6 \\
\hline F-aktin & filamentózus aktin \\
\hline FANCA & Fanconi anaemia complementation group A \\
\hline FANCG & Fanconi anaemia complementation group $\mathrm{G}$ \\
\hline FERM & 4.1 protein-Ezrin-Radixin-Moesin \\
\hline FRAP & Fluorescence Recovery After Photobleaching \\
\hline FtsA & Filamentous temperature sensitive A \\
\hline G-aktin & globuláris aktin \\
\hline GFP & $\begin{array}{l}\text { zöld fluorescensz fehérje } \\
\text { (Green Fluorescent Protein) }\end{array}$ \\
\hline gRNS & guide RNS \\
\hline hsp & hösokk fehérje (Heat Shock Protein) \\
\hline ICAM-1 & Intracellular Adhesion Molecule 1 \\
\hline mAKAP & Muscle A-kinase Anchoring Protein \\
\hline MAL & Megakaryocytic Acute Leukemia protein \\
\hline $\mathrm{MF}$ & aktin filamentum (Microfilament) \\
\hline moe & moesin \\
\hline mRNP & messenger Ribonucleoprotein Particle \\
\hline mRNS & messenger Ribonukleinsav \\
\hline MST & Micro Scale Thermophoresis \\
\hline Myo Vb, Va, VI & Myosin Vb, Va, VI \\
\hline $\mathrm{N} 1 \mathrm{IC}$ & Notch1 receptor intracelluláris domén \\
\hline NES & nukleáris export szignál \\
\hline NLS & nukleáris lokalizációs szignál \\
\hline NMI & nukleáris miozin I \\
\hline NPC & $\begin{array}{l}\text { nukleáris pórus komplex } \\
\text { (Nuclear Pore Complex) }\end{array}$ \\
\hline $\mathrm{NuA} 4$ & humán Tip60 \\
\hline Nup98 & Nukleoporin 98 \\
\hline PABP & $\begin{array}{c}\text { Poly(A) kötő fehérje } \\
\text { (Poly(A)-Binding Protein) }\end{array}$ \\
\hline PCA & $\begin{array}{c}\text { fökomponens-analízis } \\
\text { (Principal component analysis) }\end{array}$ \\
\hline ParM & plazmid szegregációs protein $\mathrm{M}$ \\
\hline PIP2 & foszfatidil-inozitol-4,5-biszfoszfát \\
\hline PKA & protein kináz $\mathrm{A}$ \\
\hline PML & $\begin{array}{l}\text { promielocitás leukémia fehérje } \\
\text { (promyelocytic leukemia protein) }\end{array}$ \\
\hline
\end{tabular}




\begin{tabular}{|c|c|}
\hline PolI, PolII & RNS-polimeráz I, II \\
\hline Rae1 & Ribonucleic acid export 1 fehérje \\
\hline RyR & Ryanodine receptor \\
\hline slik & Sterile-20 kináz \\
\hline SRF & szérum válasz faktor (Serum response factor) \\
\hline SWI/SNF & Switch/Sucrose Non-Fermentable \\
\hline SWR1 & SWI2/Snf2-related ATPase \\
\hline UV & ultraviola \\
\hline WGA & $\begin{array}{c}\text { búzacsíra agglutinin } \\
\text { (Wheat Germ Agglutinin) }\end{array}$ \\
\hline XPO1 & Exportin 1 \\
\hline YAP/TAZ & Yes associated protein/Tafazzin \\
\hline
\end{tabular}




\section{KÖSZÖNETNYILVÁNÍTÁS}

Elsőként hálásan köszönöm témavezetőmnek Dr. Vilmos Péternek, hogy csoportjában dolgozhattam, valamint az útmutatást és támogatást, amit a munkámhoz kaptam. Nagyon köszönöm a rengeteg segítséget, türelmet és iránymutatást, mely nem csak a dolgozat elkészítéséhez volt nélkülözhetetlen, hanem szakmai és emberi fejlődésemhez is.

Köszönettel tartozom a Drosophila Sejtmagi Aktin Csoport volt és jelenlegi tagjainak a munkám során nyújtott segítségükért és tanácsaikért. Külön meg szeretném köszönni Dr. Kristó Ildikónak, hogy bevezetett a sejttenyésztéssel kapcsolatos munkafolyamatokba, továbbá hogy megosztotta velem tudását, tapasztalatait. Nagyon köszönöm Abonyi Csillának a legyeken végzett élettani vizsgálatokat, emellett hálás vagyok Borkúti Péternek és Kovács Zoltánnak, hogy mindig jó szakmai hangulatban végezhettem munkámat és mindig számíthattam segítségükre.

Köszönet illeti a Genetikai Intézet összes dolgozóját, hogy olyan szakmai és támogatói légkört teremtettek, melyben öröm volt tanulni és dolgozni.

Mindenekfölött szeretném hálámat kifejezni a családomnak kitartó támogatásukért és folyamatos biztatásukért.

A dolgozatban ismertetett munkát a GINOP-2.3.2-15-2016-00001 és GINOP-2.3.215-2016-00032 pályázatok támogatásával végeztük. 


\section{IRODALOMJEGYZÉK}

1. Akoumianaki, T., Kardassis, D., Polioudaki, H., Georgattos, S. D., \& Theodoropoulos, P. A. (2009). Nucleocytoplasmic shuttling of soluble tubulin in mammalian cells. Journal of Cell Science, 122(8), 1111-1118. https://doi.org/10.1242/jcs.043034

2. Bajusz, C., Borkúti, P., Kristó, I., Kovács, Z., Abonyi, C., \& Vilmos, P. (2018). Nuclear actin: ancient clue to evolution in eukaryotes? Histochemistry and Cell Biology, 150(3), 235-244. https://doi.org/10.1007/s00418-018-1693-6

3. Batchelor, C. L., Woodward, A. M., \& Crouch, D. H. (2004). Nuclear ERM (ezrin, radixin, moesin) proteins: Regulation by cell density and nuclear import. Experimental Cell Research, 296(2), 208-222. https://doi.org/10.1016/j.yexcr.2004.02.010

4. Belin, B. J., Lee, T., \& Mullins, R. D. (2015). DNA damage induces nuclear actin filament assembly by formin-2 and spire-1/2 that promotes efficient DNA repair. ELife, 4(AUGUST2015). https://doi.org/10.7554/eLife.07735

5. Ben-Aissa, K., Patino-Lopez, G., Belkina, N. V., Maniti, O., Rosales, T., Hao, J. J., Kruhlak, M. J., Knutson, J. R., Picart, C., \& Shaw, S. (2012). Activation of moesin, a protein that links actin cytoskeleton to the plasma membrane, occurs by phosphatidylinositol 4,5-bisphosphate (PIP2) binding sequentially to two sites and releasing an autoinhibitory linker. Journal of Biological Chemistry, 287(20), 1631116323. https://doi.org/10.1074/jbc.M111.304881

6. Bhartur, S. G., \& Goldenring, J. R. (1998). Mapping of ezrin dimerization using yeast two-hybrid screening. Biochemical and Biophysical Research Communications, 243(3), 874-877. https://doi.org/10.1006/bbrc.1998.8196

7. Blessing, C. A., Ugrinova, G. T., \& Goodson, H. V. (2004). Actin and ARPs: Action in the nucleus. Trends in Cell Biology, 14(8), 435-442. https://doi.org/10.1016/j.tcb.2004.07.009

8. Borden, K. L. B. (2002). Pondering the Promyelocytic Leukemia Protein (PML) Puzzle: Possible Functions for PML Nuclear Bodies. Molecular and Cellular Biology, 22(15), 5259-5269. https://doi.org/10.1128/mcb.22.15.5259-5269.2002

9. C., X., V., M.-S., L., S., \& R.M., R. (2007). Targeting HSP70 to motoneurons protects locomotor activity from hyperthermia in Drosophila. Developmental Neurobiology.

10. Carroll, D. (2011). Genome engineering with zinc-finger nucleases. Genetics, 188(4), 773-782. https://doi.org/10.1534/genetics.111.131433

11. Clucas, J., \& Valderrama, F. (2014). ERM proteins in cancer progression. In Journal of Cell Science (Vol. 127, Issue 2, pp. 267-275). https://doi.org/10.1242/jcs.133108

12. Cobreros, L., Fernández-Miñán, A., Luque, C. M., González-Reyes, A., \& MartínBermudo, M. D. (2008). A role for the chaperone Hsp70 in the regulation of border cell migration in the Drosophila ovary. Mechanisms of Development, 125(11-12), 1048-1058. https://doi.org/10.1016/j.mod.2008.07.006

13. De Lanerolle, P. (2012). Nuclear actin and myosins at a glance. Journal of Cell Science, 125(21), 4945-4949. https://doi.org/10.1242/jcs.099754

14. Dion, V., Shimada, K., \& Gasser, S. M. (2010). Actin-related proteins in the nucleus: 
Life beyond chromatin remodelers. In Current Opinion in Cell Biology (Vol. 22, Issue 3, pp. 383-391). https://doi.org/10.1016/j.ceb.2010.02.006

15. Dopie, J., Skarp, K. P., Rajakylä, E. K., Tanhuanpää, K., \& Vartiainen, M. K. (2012). Active maintenance of nuclear actin by importin 9 supports transcription. Proceedings of the National Academy of Sciences of the United States of America, 109(9). https://doi.org/10.1073/pnas.1118880109

16. Erickson, H. P. (2007). Evolution of the cytoskeleton. In BioEssays (Vol. 29, Issue 7, pp. 668-677). https://doi.org/10.1002/bies.20601

17. Falahzadeh, K., Banaei-Esfahani, A., \& Shahhoseini, M. (2015). The potential roles of actin in the nucleus. In Cell Journal (Vol. 17, Issue 1, pp. 7-14).

18. Fiévet, B., Louvard, D., \& Arpin, M. (2007). ERM proteins in epithelial cell organization and functions. In Biochimica et Biophysica Acta - Molecular Cell Research (Vol. 1773, Issue 5, pp. 653-660). https://doi.org/10.1016/j.bbamcr.2006.06.013

19. Gary, R., \& Bretscher, A. (1995). Ezrin self-association involves binding of an Nterminal domain to a normally masked $\mathrm{C}$-terminal domain that includes the F-actin binding site. Molecular Biology of the Cell, 6(8), 1061-1075. https://doi.org/10.1091/mbc.6.8.1061

20. Gong, W. J., \& Golic, K. G. (2006). Loss of Hsp70 in drosophila is pleiotropic, with effects on thermotolerance, recovery from heat shock and neurodegeneration. Genetics, 172(1), 275-286. https://doi.org/10.1534/genetics.105.048793

21. Goo, Y.-H., Sohn, Y. C., Kim, D.-H., Kim, S.-W., Kang, M.-J., Jung, D.-J., Kwak, E., Barlev, N. A., Berger, S. L., Chow, V. T., Roeder, R. G., Azorsa, D. O., Meltzer, P. S., Suh, P.-G., Song, E. J., Lee, K.-J., Lee, Y. C., \& Lee, J. W. (2003). Activating Signal Cointegrator 2 Belongs to a Novel Steady-State Complex That Contains a Subset of Trithorax Group Proteins. Molecular and Cellular Biology, 23(1), 140149. https://doi.org/10.1128/mcb.23.1.140-149.2003

22. Guettler, S., Vartiainen, M. K., Miralles, F., Larijani, B., \& Treisman, R. (2008). RPEL Motifs Link the Serum Response Factor Cofactor MAL but Not Myocardin to Rho Signaling via Actin Binding. Molecular and Cellular Biology, 28(2), 732-742. https://doi.org/10.1128/mcb.01623-07

23. Harreman, M. T., Kline, T. M., Milford, H. G., Harben, M. B., Hodel, A. E., \& Corbett, A. H. (2004). Regulation of nuclear import by phosphorylation adjacent to nuclear localization signals. Journal of Biological Chemistry, 279(20), 2061320621. https://doi.org/10.1074/jbc.M401720200

24. Hofmann, W. A. (2009). Chapter 6 Cell and Molecular Biology of Nuclear Actin. International Review of Cell and Molecular Biology, 273(C), 219-263. https://doi.org/10.1016/S1937-6448(08)01806-6

25. Hofmann, W. A., Stojiljkovic, L., Fuchsova, B., Vargas, G. M., Mavrommatis, E., Philimonenko, V., Kysela, K., Goodrich, J. A., Lessard, J. L., Hope, T. J., Hozak, P., $\&$ de Lanerolle, P. (2004). Actin is part of pre-initiation complexes and is necessary for transcription by RNA polymerase II. Nature Cell Biology, 6(11), 1094-1101. https://doi.org/10.1038/ncb1182

26. Jankovics, F., Bence, M., Sinka, R., Faragó, A., Bodai, L., Pettkó-Szandtner, A., Ibrahim, K., Takács, Z., Szarka-Kovács, A. B., \& Erdélyi, M. (2018). Drosophila 
small ovary gene is required for transposon silencing and heterochromatin organization, and ensures germline stem cell maintenance and differentiation. Development (Cambridge), 145(23). https://doi.org/10.1242/dev.170639

27. Jankovics, F., Sinka, R., Lukácsovich, T., \& Erdélyi, M. (2002). MOESIN crosslinks actin and cell membrane in Drosophila oocytes and is required for OSKAR anchoring. Current Biology, 12(23), 2060-2065. https://doi.org/10.1016/S09609822(02)01256-3

28. Ji, Z. L., Duan, Y. G., Mou, L. S., Allam, J. P., Haidl, G., \& Cai, Z. M. (2012). Association of heat shock proteins, heat shock factors and male infertility. Asian Pacific Journal of Reproduction, 1(1), 76-84. https://doi.org/10.1016/S23050500(13)60053-6

29. Kabsch, W., \& Holmes, K. C. (1995). The actin fold. In FASEB Journal (Vol. 9, Issue 2, pp. 167-174). https://doi.org/10.1096/fasebj.9.2.7781919

30. Kalendová, A., Kalasová, I., Yamazaki, S., Uličná, L., Harata, M., \& Hozák, P. (2014). Nuclear actin filaments recruit cofilin and actin-related protein 3, and their formation is connected with a mitotic block. Histochemistry and Cell Biology, 142(2), 139-152. https://doi.org/10.1007/s00418-014-1243-9

31. Kapoor, P., \& Shen, X. (2014). Mechanisms of nuclear actin in chromatinremodeling complexes. In Trends in Cell Biology (Vol. 24, Issue 4, pp. 238-246). https://doi.org/10.1016/j.tcb.2013.10.007

32. Kjærsgaard, A., Demontis, D., Kristensen, T. N., Le, N., Faurby, S., Pertoldi, C., Sørensen, J. G., \& Loeschcke, V. (2010). Locomotor activity of Drosophila melanogaster in high temperature environments: Plastic and evolutionary responses. Climate Research. https://doi.org/10.3354/cr00870

33. Klikova, K., Pilchova, I., Stefanikova, A., Hatok, J., Dobrota, D., \& Racay, P. (2016). The role of heat shock proteins in Leukemia. Klinicka Onkologie, 29(1), 29-38. https://doi.org/10.14735/amko201629

34. Knoll, K. R., Eustermann, S., Niebauer, V., Oberbeckmann, E., Stoehr, G., Schall, K., Tosi, A., Schwarz, M., Buchfellner, A., Korber, P., \& Hopfner, K. P. (2018). The nuclear actin-containing Arp8 module is a linker DNA sensor driving INO80 chromatin remodeling. Nature Structural and Molecular Biology, 25(9), 823-832. https://doi.org/10.1038/s41594-018-0115-8

35. Kristó, I., Bajusz, C., Borsos, B. N., Pankotai, T., Dopie, J., Jankovics, F., Vartiainen, M. K., Erdélyi, M., \& Vilmos, P. (2017). The actin binding cytoskeletal protein Moesin is involved in nuclear mRNA export. Biochimica et Biophysica Acta Molecular Cell Research, 1864(10), 1589-1604. https://doi.org/10.1016/j.bbamcr.2017.05.020

36. Kristó, I., Bajusz, I., Bajusz, C., Borkúti, P., \& Vilmos, P. (2016). Actin, actinbinding proteins, and actin-related proteins in the nucleus. In Histochemistry and Cell Biology (Vol. 145, Issue 4, pp. 373-388). https://doi.org/10.1007/s00418-0151400-9

37. Kumeta, M., Yoshimura, S. H., Hejna, J., \& Takeyasu, K. (2012). Nucleocytoplasmic shuttling of cytoskeletal proteins: Molecular mechanism and biological significance. In International Journal of Cell Biology. https://doi.org/10.1155/2012/494902

38. Li, Q., \& Sarna, S. K. (2009). Nuclear Myosin II Regulates the Assembly of 
Preinitiation Complex for ICAM-1 Gene Transcription. Gastroenterology, 137(3). https://doi.org/10.1053/j.gastro.2009.03.040

39. Lindsay, A. J., \& McCaffrey, M. W. (2009). Myosin Vb localises to nucleoli and associates with the RNA polymerase I transcription complex. Cell Motility and the Cytoskeleton, 66(12), 1057-1072. https://doi.org/10.1002/cm.20408

40. Louvet-Vallée, S. (2000). ERM proteins: From cellular architecture to cell signaling. In Biology of the Cell (Vol. 92, Issue 5, pp. 305-316). https://doi.org/10.1016/S02484900(00)01078-9

41. Lynn Zimmerman, J., Petri, W., \& Meselson, M. (1983). Accumulation of a specific subset of D. melanogaster heat shock mRNAs in normal development without heat shock. Cell. https://doi.org/10.1016/0092-8674(83)90299-4

42. Maniti, O., Khalifat, N., Goggia, K., Dalonneau, F., Guérin, C., Blanchoin, L., Ramos, L., \& Picart, C. (2012). Binding of moesin and ezrin to membranes containing phosphatidylinositol $(4,5)$ bisphosphate: A comparative study of the affinity constants and conformational changes. Biochimica et Biophysica Acta Biomembranes, $1818(11)$, 2839-2849. https://doi.org/10.1016/j.bbamem.2012.07.004

43. Manjila, S., \& Hasan, G. (2018). Flight and Climbing Assay for Assessing Motor Functions in Drosophila. Bio-Protocol, https://doi.org/10.21769/bioprotoc. 2742

44. McClatchey, A. I. (2014). ERM proteins at a glance. Journal of Cell Science, 127(15), 3199-3204. https://doi.org/10.1242/jcs.098343

45. McDonald, D., Carrero, G., Andrin, C., De Vries, G., \& Hendzel, M. J. (2006). Nucleoplasmic $\beta$-actin exists in a dynamic equilibrium between low-mobility polymeric species and rapidly diffusing populations. Journal of Cell Biology, 172(4), 541-552. https://doi.org/10.1083/jcb.200507101

46. McKean, P. G., Vaughan, S., \& Gull, K. (2001). The extended tubulin superfamily. Journal of Cell Science, 114(15), 2723-2733.

47. Menko, A. S., \& Tan, K. B. (1980). Nuclear tubulin of tissue culture cells. BBA General Subjects, 629(2), 359-370. https://doi.org/10.1016/0304-4165(80)90108-7

48. Michie, K. A., Bermeister, A., Robertson, N. O., Goodchild, S. C., \& Curmi, P. M. G. (2019). Two Sides of the Coin: Ezrin/Radixin/Moesin and Merlin Control Membrane Structure and Contact Inhibition. In International journal of molecular sciences. https://doi.org/10.3390/ijms20081996

49. Nardozzi, J. D., Lott, K., \& Cingolani, G. (2010). Phosphorylation meets nuclear import: A review. In Cell Communication and Signaling (Vol. 8). https://doi.org/10.1186/1478-811X-8-32

50. Ohnishi, T., Kawamura, H., \& Yamamoto, T. (1963). Extraction of a Protein Resembling Actin From the Cell Nucleus of the Calf Thymus. Journal of Biochemistry, 54, 298-300. http://www.ncbi.nlm.nih.gov/pubmed/14070462

51. Oma, Y., \& Harata, M. (2011). Actin-related proteins localized in the nucleus: From discovery to novel roles in nuclear organization. In Nucleus (Vol. 2, Issue 1, pp. 38 46). https://doi.org/10.4161/nucl.2.1.14510

52. Parameswaran, N., \& Gupta, N. (2013). Re-defining ERM function in lymphocyte 
activation and migration. Immunological Reviews, 256(1), 63-79. https://doi.org/10.1111/imr.12104

53. Pawłowski, R., Rajakylä, E. K., Vartiainen, M. K., \& Treisman, R. (2010). An actinregulated importin $\alpha / \beta$-dependent extended bipartite NLS directs nuclear import of $\begin{array}{llll}\text { MRTF-A. } & \text { EMBO } & \text { Journal, } & \text { 3448-3458), }\end{array}$ https://doi.org/10.1038/emboj.2010.216

54. Percipalle, P. (2013). Co-transcriptional nuclear actin dynamics. In Nucleus (United States) (Vol. 4, Issue 1, pp. 1-10). https://doi.org/10.4161/nucl.22798

55. Percipalle, P., \& Visa, N. (2006). Molecular functions of nuclear actin in transcription. In Journal of Cell Biology (Vol. 172, Issue 7, pp. 967-971). https://doi.org/10.1083/jcb.200512083

56. Perrin, B. J., \& Ervasti, J. M. (2010). The actin gene family: Function follows isoform. Cytoskeleton, 67(10), 630-634. https://doi.org/10.1002/cm.20475

57. Pestic-Dragovich, L., Stojiljkovic, L., Philimonenko, A. A., Nowak, G., Ke, Y., Settlage, R. E., Shabanowitz, J., Hunt, D. F., Hozak, P., \& De Lanerolle, P. (2000). A myosin I isoform in the nucleus. Science, 290(5490), 337-340. https://doi.org/10.1126/science.290.5490.337

58. Phang, J. M., Harrop, S. J., Duff, A. P., Sokolova, A. V., Crossett, B., Walsh, J. C., Beckham, S. A., Nguyen, C. D., Davies, R. B., Glöckner, C., Bromley, E. H. C., Wilk, K. E., \& Curmi, P. M. G. (2016). Structural characterization suggests models for monomeric and dimeric forms of full-length ezrin. Biochemical Journal, 473(18), 2763-2782. https://doi.org/10.1042/BCJ20160541

59. Philimonenko, V. V., Zhao, J., Iben, S., Dingová, H., Kyselá, K., Kahle, M., Zentgraf, H., Hofmann, W. A., de Lanerolle, P., Hozák, P., \& Grummt, I. (2004). Nuclear actin and myosin I are required for RNA polymerase I transcription. Nature Cell Biology, 6(12), 1165-1172. https://doi.org/10.1038/ncb1190

60. Polesello, C., \& Payre, F. (2004). Small is beautiful: What flies tell us about ERM protein function in development. In Trends in Cell Biology (Vol. 14, Issue 6, pp. 294-302). https://doi.org/10.1016/j.tcb.2004.04.003

61. Pollard, T. D. (2001). Genomics, the cytoskeleton and motility. In Nature (Vol. 409, Issue 6822, pp. 842-843). https://doi.org/10.1038/35057029

62. Polosello, C., Delon, I., Valenti, P., Ferrer, P., \& Payre, F. (2002). Dmoesin controls actin-based cell shape and polarity during Drosophila melanogaster oogenesis. Nature Cell Biology, 4(10), 782-789. https://doi.org/10.1038/ncb856

63. Posern, G., Sotiropoulos, A., \& Treisman, R. (2002). Mutant actins demonstrate a role for unpolymerized actin in control of transcription by serum response factor. Molecular Biology of the Cell, 13(12), 4167-4178. https://doi.org/10.1091/mbc.0205-0068

64. Pranchevicius, M. C. S., Baqui, M. M. A., Ishikawa-Ankerhold, H. C., Lourenço, E. V., Leão, R. M., Banzi, S. R., Dos Santos, C. T., Barreira, M. C. R., Espreafico, E. M., \& Larson, R. E. (2008). Myosin Va phosphorylated on Ser1650 is found in nuclear speckles and redistributes to nucleoli upon inhibition of transcription. Cell Motility and the Cytoskeleton, 65(6), 441-456. https://doi.org/10.1002/cm.20269

65. Roch, F., Polesello, C., Roubinet, C., Martin, M., Roy, C., Valenti, P., Carreno, S., Mangeat, P., \& Payre, F. (2010). Differential roles of PtdIns(4,5)P2and 
phosphorylation in moesin activation during Drosophila development. Journal of Cell Science, 123(12), 2058-2067. https://doi.org/10.1242/jcs.064550

66. Roy, C., Martin, M., \& Mangeat, P. (1997). A dual involvement of the aminoterminal domain of ezrin in F- and G- actin binding. Journal of Biological Chemistry, 272(32), 20088-20095. https://doi.org/10.1074/jbc.272.32.20088

67. Ruksha, K., Mezheyeuski, A., Nerovnya, A., Bich, T., Tur, G., Gorgun, J., Luduena, R., \& Portyanko, A. (2019). Over-Expression of $\beta$ II-Tubulin and Especially Its Localization in Cell Nuclei Correlates with Poorer Outcomes in Colorectal Cancer. Cells, 8(1), 25. https://doi.org/10.3390/cells8010025

68. Schoenenberger, C. A., Buchmeier, S., Boerries, M., Sütterlin, R., Aebi, U., \& Jockusch, B. M. (2005). Conformation-specific antibodies reveal distinct actin structures in the nucleus and the cytoplasm. Journal of Structural Biology, 152(3), 157-168. https://doi.org/10.1016/j.jsb.2005.09.003

69. Smith, S. S., Kelly, K. H., \& Jockusch, B. M. (1979). Actin co-purifies with RNA polymerase II. Biochemical and Biophysical Research Communications, 86(1), 161166. https://doi.org/10.1016/0006-291X(79)90395-4

70. Sorek, R., Lawrence, C. M., \& Wiedenheft, B. (2013). CRISPR-Mediated Adaptive Immune Systems in Bacteria and Archaea. Annual Review of Biochemistry, 82(1), 237-266. https://doi.org/10.1146/annurev-biochem-072911-172315

71. Sridharan, D., Brown, M., Lambert, W. C., McMahon, L. W., \& Lambert, M. W. (2003). Nonerythroid $\alpha$ II spectrin is required for recruitment of FANCA and XPF to nuclear foci induced by DNA interstrand cross-links. In Journal of Cell Science (Vol. 116, Issue 5, pp. 823-835). https://doi.org/10.1242/jcs.00294

72. Venit, T., Semesta, K., Farrukh, S., Endara-Coll, M., Havalda, R., Hozak, P., \& Percipalle, P. (2020). Nuclear myosin 1 activates p21 gene transcription in response to DNA damage through a chromatin-based mechanism. Communications Biology. https://doi.org/10.1038/s42003-020-0836-1

73. Vilmos, P., Kristó, I., Szikora, S., Jankovics, F., Lukácsovich, T., Kari, B., \& Erdélyi, M. (2016). The actin-binding ERM protein Moesin directly regulates spindle assembly and function during mitosis. Cell Biology International, 40(6), 696-707. https://doi.org/10.1002/cbin.10607

74. Vos, M. J., Carra, S., Kanon, B., Bosveld, F., Klauke, K., Sibon, O. C. M., \& Kampinga, H. H. (2016). Specific protein homeostatic functions of small heat-shock proteins increase lifespan. Aging Cell. https://doi.org/10.1111/acel.12422

75. Vreugde, S., Ferrai, C., Miluzio, A., Hauben, E., Marchisio, P. C., Crippa, M. P., Bussi, M., \& Biffo, S. (2006). Nuclear Myosin VI Enhances RNA Polymerase IIDependent Transcription. Molecular Cell, 23(5), 749-755. https://doi.org/10.1016/j.molcel.2006.07.005

76. Walss-Bass, C., Xu, K., David, S., Fellous, A., \& Ludueña, R. F. (2002). Occurrence of nuclear $\beta$ II-tubulin in cultured cells. Cell and Tissue Research, 308(2), 215-223. https://doi.org/10.1007/s00441-002-0539-6

77. Wang, H. D., Kazemi-Esfarjani, P., \& Benzer, S. (2004). Multiple-stress analysis for isolation of Drosophila longevity genes. Proceedings of the National Academy of Sciences of the United States of America, 101(34), 12610-12615. https://doi.org/10.1073/pnas.0404648101 
78. Wesolowska, N., \& Lénárt, P. (2015). Nuclear roles for actin. Chromosoma, 124(4), 481-489. https://doi.org/10.1007/s00412-015-0519-8

79. Wineland, D. M., Kelpsch, D. J., \& Tootle, T. L. (2018). Multiple Pools of Nuclear Actin. Anatomical Record, 301(12), 2014-2036. https://doi.org/10.1002/ar.23964

80. Xu, K., \& Ludueña, R. F. (2002). Characterization of nuclear $\beta$ II-tubulin in tumor cells: A possible novel target for taxol. Cell Motility and the Cytoskeleton, 53(1), 3952. https://doi.org/10.1002/cm.10060

81. Yeh, T. S., Hsieh, R. H., Shen, S. C., Wang, S. H., Tseng, M. J., Shih, C. M., \& Lin, J. J. (2004). Nuclear $\beta$ II-tubulin associates with the activated notch receptor to modulate notch signaling. Cancer Research, 64(22), 8334-8340. https://doi.org/10.1158/0008-5472.CAN-04-2197

82. Yoo, Y., Wu, X., \& Guan, J. L. (2007). A novel role of the actin-nucleating Arp2/3 complex in the regulation of RNA polymerase II-dependent transcription. Journal of Biological Chemistry, 282(10), 7616-7623. https://doi.org/10.1074/jbc.M607596200

83. Young, K. G., \& Kothary, R. (2005). Spectrin repeat proteins in the nucleus. In BioEssays (Vol. 27, Issue 2, pp. 144-152). https://doi.org/10.1002/bies.20177 


\section{SAJÁT KÖZLEMÉNYEK LISTÁJA}

MTMT azonosító: 10052993

Összesített impakt faktor: 16,856

Nuclear actin: ancient clue to evolution in eukaryotes?

Bajusz Cs., Borkúti P., Kristó I., Kovács Z., Abonyi C., Vilmos P.

Histochem Cell Biol. 2018 Sep;150(3), 235-244.

http://dx.doi.org/10.1007/s00418-018-1693-6

PMID: 30019087, IF: 2,64 (2018)

Characterization of the nuclear localization signal of the actin-binding Moesin protein.

Bajusz C., Kristó I., Borkúti P., Kovács Z., Vilmos P.

Biopolym. Cell 2019; 35(3):201.

http://dx.doi.org/10.7124/bc.0009D2

IF: 0,3 (2018)

Investigation the role in mRNA export of the actin binding protein, Moesin

Kristó I., Bajusz C., Borkúti P., Kovács Z., Pettkó-Szandtner A., Vilmos P.

Biopolym. Cell 2019; 35(3):219-220.

http://dx.doi.org/10.7124/bc.0009E9

IF: 0,3 (2018)

Testing the biological significance of the nuclear localization of actin.

Borkúti P., Bajusz I., Bajusz C., Kristó I., Kovács Z., Vilmos P.

Biopolym. Cell 2019; 35(3):204-204.

http://dx.doi.org/10.7124/bc.000A06

IF: 0,3 (2018)

The actin binding cytoskeletal protein Moesin is involved in nuclear mRNA export.

Kristó I., Bajusz Cs., Borsos B.N., Pankotai T., Dopie J., Jankovics F., Vartiainen M.K., Erdélyi M., Vilmos P

Bioch Biophys Acta-Mol Cell Res 1864:10 pp. 1589-1604.,16 p.(2017)

http://dx.doi.org/10.1016/j.bbamcr.2017.05.020

PMID:28554770, IF: 2,68 (2017)

Actin, actin-binding proteins, and actin-related proteins in the nucleus.

Kristó I., Bajusz I., Bajusz Cs., Borkúti P., Vilmos P.

Histochem Cell Biol. 2016 Apr;145(4):373-88.

http://dx.doi.org/10.1007/s00418-015-1400-9

PMID:26847179, IF: 2,55 (2015) 
Drosophila Atg9 regulates the actin cytoskeleton via interactions with profilin and Ena.

Kiss V., Jipa A., Varga K., Takáts S. Maruzs T., Lőrincz P., Simon-Vecsei Z., Szikora S., Földi I., Bajusz Cs., Tóth D., Vilmos P., Gáspár I., Ronchi P., Mihály J.,Juhász G.

Cell Death Differ (2019) 27, p. 1677-1692(2020).

https://dx.doi.org/10.1038/s41418-019-0452-0

PMID:31740789, IF: 8,086 (2018/2019) 